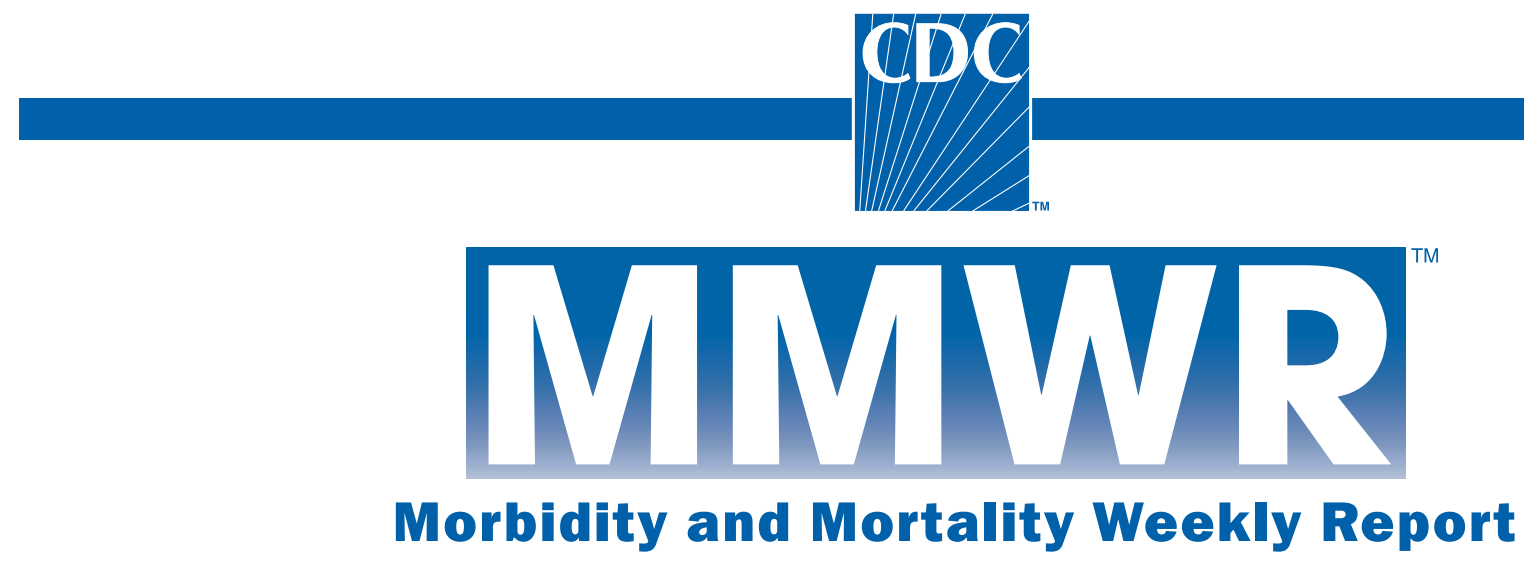

Weekly

July 1, 2005 / Vol. 54 / No. 25

\title{
Annual Smoking-Attributable Mortality, Years of Potential Life Lost, and Productivity Losses — United States, 1997-2001
}

Smoking harms nearly every organ of the body, causing many diseases and reducing quality of life and life expectancy (1). This report assesses the health consequences and productivity losses attributable to smoking in the United States during 19972001. CDC calculated national estimates of annual smokingattributable mortality (SAM), years of potential life lost (YPLL) for adults and infants, and productivity losses for adults. The findings indicated that, during 1997-2001, cigarette smoking and exposure to tobacco smoke resulted in approximately 438,000 premature deaths in the United States, 5.5 million YPLL, and $\$ 92$ billion in productivity losses annually. Implementation of comprehensive tobacco-control programs as recommended by CDC can reduce smoking prevalence and related mortality and health-care costs (1).

The Adult and Maternal and Child Health SmokingAttributable Mortality, Morbidity and Economic Cost (SAMMEC) software (2) was revised on the basis of findings from the 2004 Surgeon General's report on diseases caused by smoking (1). The list of smoking-attributable diseases now includes stomach cancer and acute myeloid leukemia and excludes hypertension. Sex- and age-specific smokingattributable deaths were calculated by multiplying the total number of deaths for 19 adult and four infant disease categories by estimates of the smoking-attributable fraction (SAF) of preventable deaths. The attributable fractions provide estimates of the public health burden of each risk factor and the relative importance of risk factors for multifactorial diseases. Because of the effect of interactions between various risk factors, attributable fractions for a given disease can add up to more than $100 \%$. For adults, SAFs were derived by using sexspecific relative risk (RR) estimates (2) for current and former smokers for each cause of death from the American Cancer Society's Cancer Prevention Study-II (CPS-II) for the period 1982-1988 (2). For ischemic heart disease and cerebrovascular disease deaths, RR estimates were also stratified by age (35-64 years and $\geq 65$ years). SAFs also used sex- and agespecific (35-64 years and $\geq 65$ years) current and former cigarette smoking-prevalence estimates from the National Health Interview Survey. ${ }^{*}$ For infants, SAFs were calculated by using pediatric RR estimates (2) and maternal smoking prevalence estimates from birth certificates (2). Smoking-attributable YPLL and productivity losses were estimated by multiplying sex- and age-specific SAM by remaining life expectancy (3) and lifetime earnings data (4). In addition, smoking-attributable fire-related deaths (5) and lung cancer and heart disease deaths attributable to exposure to secondhand smoke $(6,7)$ were included in the SAM estimates.

During 1997-2001, smoking resulted in an estimated annual average of 259,494 deaths among men and 178,408 deaths among women in the United States (Table). Among adults, $158,529(39.8 \%)$ of these deaths were attributed to cancer, $137,979(34.7 \%)$ to cardiovascular diseases, and $101,454(25.5 \%)$ to respiratory diseases. The three leading specific causes of smoking-attributable death were lung

\footnotetext{
*SAFs for each disease are calculated by using the following equation: $\mathrm{SAF}=$ $\left[\left(\mathrm{p}_{1}\left(\mathrm{RR}_{1}-1\right)+\mathrm{p}_{2}\left(\mathrm{RR}_{2}-1\right)\right] /\left[\mathrm{p}_{1}\left(\mathrm{RR}_{1}-1\right)+\mathrm{p}_{2}\left(\mathrm{RR}_{2}-1\right)+1\right]\right.$ where $\mathrm{p}_{1}=$ percentage of current smokers (persons who have smoked $\geq 100$ cigarettes and now smoke every day or some days), $\mathrm{p}_{2}=$ percentage of former smokers (persons who have smoked $\geq 100$ cigarettes and do not currently smoke), $R_{1}=$ relative risk for current smokers relative to never smokers, and $\mathrm{RR}_{2}=$ relative risk for former smokers relative to never smokers.
} 
The $M M W R$ series of publications is published by the Coordinating Center for Health Information and Service, Centers for Disease Control and Prevention (CDC), U.S. Department of Health and Human Services, Atlanta, GA 30333.

\section{SUGGESTED CITATION}

Centers for Disease Control and Prevention. [Article Title]. MMWR 2005;54:[inclusive page numbers].

Centers for Disease Control and Prevention

Julie L. Gerberding, MD, MPH

Director

Dixie E. Snider, MD, MPH

Chief Science Officer

Tanja Popovic, MD, $\mathrm{PhD}$

(Acting) Associate Director for Science

\section{Coordinating Center for Health Information and Service}

Blake Caldwell, MD, MPH, and Edward J. Sondik, PhD (Acting) Directors

\section{National Center for Health Marketing* \\ Steven L. Solomon, MD \\ (Acting) Director}

\section{Division of Scientific Communications*}

Maria S. Parker

(Acting) Director

Mary Lou Lindegren, MD

(Acting) Editor, MMWR Series

Suzanne M. Hewitt, MPA

Managing Editor, MMWR Series

Douglas W. Weatherwax

(Acting) Lead Technical Writer-Editor

Stephanie M. Neitzel

Jude C. Rutledge

Writers-Editors

Lynda G. Cupell

Malbea A. LaPete

Visual Information Specialists

Quang M. Doan, MBA

Erica R. Shaver

Information Technology Specialists

Notifiable Disease Morbidity and 122 Cities Mortality Data

Patsy A. Hall

Donna Edwards

Deborah A. Adams

Felicia J. Connor

Tambra McGee

Rosaline Dhara cancer $(123,836)$, chronic obstructive pulmonary disease $(\mathrm{COPD})^{\dagger}(90,582)$, and ischemic heart disease $(86,801)$. Smoking during pregnancy resulted in an estimated 910 infant deaths annually during 1997-2001. An estimated 38,112 lung cancer and heart disease deaths annually were attributable to exposure to secondhand smoke. The average annual SAM estimates also included 918 deaths from smokingattributable fires.

During 1997-2001, on average, smoking accounted for an estimated 3.3 million YPLL for men and 2.2 million YPLL for women annually, excluding burn deaths and adult deaths from secondhand smoke. Estimates for average annual smoking-attributable productivity losses were approximately $\$ 61.9$ billion for men and $\$ 30.5$ billion for women during this period (Table).

Reported by: $B S$ Armour, PhD, T Woollery, PhD, A Malarcher, PhD, TF Pechacek, PhD, C Husten, MD, Office on Smoking and Health, National Center for Chronic Disease Prevention and Health Promotion, $C D C$.

Editorial Note: During 1997-2001, an estimated 438,000 persons in the United States died prematurely each year as a result of smoking or exposure to secondhand smoke. This figure is lower than the average annual estimate of approximately 440,000 deaths during 1995-1999 (8) because of changes in the list of smoking-attributable diseases and declines in the prevalence of smoking. Accelerated reductions in the prevalence of smoking could prevent millions of premature deaths (1).

The findings in this report are subject to at least six limitations. First, the estimates understate deaths attributable to tobacco use because estimates of deaths attributable to cigar smoking, pipe smoking, and smokeless tobacco use were excluded. Second, RRs were based on deaths during 1982-1988 among birth cohorts who might have had different smoking histories than current or former smokers (e.g., age of initiation and duration of smoking before quitting). Third, this report used a death certificate-based definition of COPD, including codes for bronchitis/emphysema and chronic airway obstruction (ICD-10 J44) (1). Therefore, the COPD SAM estimate used for this report might differ from other estimates that use other definitions of COPD (1). Fourth, RRs were adjusted for the effects of age but not for other potential confounders. However, research suggests that education, alcohol, and other confounders had negligible additional impact on SAM estimates for lung cancer, COPD, ischemic heart disease, and cerebrovascular disease in CPS-II (2). Fifth, productivity losses understate the total costs of

\footnotetext{
$\dagger$ COPD includes bronchitis/emphysema (International Classification of Diseases, Tenth Revision [ICD-10] codes J40-J42 and J43) and chronic airway obstruction (ICD-10 J44) (1).
} 
TABLE. Annual deaths and estimates of smoking-attributable mortality (SAM), years of potential life lost (YPLL), and productivity losses (PLoss), by sex and cause of death — United States, 1997-2001

\begin{tabular}{|c|c|c|c|c|c|c|c|c|}
\hline \multirow[b]{2}{*}{ Cause of death (ICD-10* code) } & \multicolumn{4}{|c|}{ Male } & \multicolumn{4}{|c|}{ Female } \\
\hline & Deaths & SAM & YPLL & PLoss $^{\dagger}$ & Deaths & SAM & YPLL & PLoss \\
\hline \multicolumn{9}{|l|}{ Malignant neoplasms } \\
\hline Lip, oral cavity, pharynx (C00-C14) & 4,973 & 3,686 & 63,153 & $1,407,108$ & 2,525 & 1,182 & 19,710 & 329,290 \\
\hline Esophagus (C15) & 9,037 & 6,533 & 101,057 & $2,075,079$ & 2,854 & 1,625 & 25,002 & 377,256 \\
\hline Stomach (C16) & 7,403 & 2,052 & 29,435 & 576,855 & 5,223 & 600 & 9,163 & 142,908 \\
\hline Pancreas (C25) & 13,984 & 3,078 & 48,337 & $1,011,388$ & 14,774 & 3,431 & 51,555 & 766,122 \\
\hline Larynx (C32) & 3,017 & 2,499 & 38,241 & 775,821 & 816 & 596 & 10,375 & 172,820 \\
\hline Trachea, lung, bronchus (C33-C34) & 89,912 & 79,026 & $1,113,644$ & $20,950,648$ & 63,181 & 44,810 & 740,221 & $11,796,204$ \\
\hline Cervix uteri (C53) & - & - & - & - & 3,989 & 491 & 12,959 & 300,078 \\
\hline Kidney, other urinary (C64-65) & 7,169 & 2,790 & 43,091 & 891,392 & 4,454 & 222 & 3,861 & 66,482 \\
\hline Urinary bladder (C67) & 8,025 & 3,764 & 42,204 & 637,445 & 3,841 & 1,054 & 12,958 & 150,902 \\
\hline Acute myeloid leukemia (C92.0) & 3,447 & 791 & 11,664 & 233,255 & 2,919 & 299 & 4,989 & 83,554 \\
\hline Total & 146,967 & 104,219 & $1,490,826$ & $28,558,991$ & 104,576 & 54,310 & 890,793 & $14,185,616$ \\
\hline \multicolumn{9}{|l|}{ Cardiovascular diseases } \\
\hline Ischemic heart disease (I20-I25) & 262,968 & 54,629 & 848,560 & $17,962,696$ & 256,871 & 32,172 & 426,108 & $5,758,053$ \\
\hline Other heart disease (I00-I09, I26-I51) & 70,368 & 13,006 & 169,552 & $3,148,168$ & 92,173 & 7,937 & 95,948 & $1,168,287$ \\
\hline Cerebrovascular disease (I60-169) & 64,074 & 8,543 & 135,609 & $2,942,167$ & 101,873 & 8,893 & 151,945 & $2,715,092$ \\
\hline Atherosclerosis (I70-I71) & 5,444 & 1,439 & 13,394 & 158,581 & 9,276 & 759 & 6,822 & 41,664 \\
\hline Aortic aneurysm (I71) & 9,635 & 6,203 & 75,640 & $1,263,516$ & 6,185 & 3,046 & 37,129 & 423,261 \\
\hline Other arterial disease (172-178) & 4,188 & 547 & 7,200 & 132,202 & 5,585 & 805 & 10,246 & 131,435 \\
\hline Total & 416,677 & 84,367 & $1,249,955$ & $25,607,330$ & 471,963 & 53,612 & 728,198 & $10,237,792$ \\
\hline \multicolumn{9}{|l|}{ Respiratory diseases } \\
\hline Pneumonia, influenza (J10-J18) & 27,389 & 6,170 & 60,862 & 814,279 & 34,748 & 4,702 & 49,577 & 483,219 \\
\hline Bronchitis, emphysema (J40-J42, J43) & 9,455 & 8,586 & 97,003 & $1,442,012$ & 8,594 & 6,922 & 90,537 & $1,085,109$ \\
\hline Chronic airway obstruction (J44) & 48,644 & 39,563 & 411,713 & $5,515,658$ & 47,769 & 35,511 & 427,097 & $4,588,079$ \\
\hline Total & 85,488 & 54,319 & 569,578 & $7,771,949$ & 91,111 & 47,135 & 567,211 & $6,156,407$ \\
\hline \multicolumn{9}{|l|}{ Perinatal conditions } \\
\hline Short gestation/low birthweight (P07) & 2,435 & 230 & 17,024 & - & 1,980 & 187 & 14,870 & - \\
\hline Respiratory distress syndrome (P22) & 688 & 25 & 1,863 & - & 468 & 17 & 1,368 & 一 \\
\hline Other respiratory (newborn) (P23-28) & 891 & 44 & 3,239 & - & 640 & 31 & 2,481 & 一 \\
\hline Sudden infant death syndrome (R95) & 1,603 & 224 & 16,587 & - & 1,082 & 152 & 12,053 & 一 \\
\hline Total & 5,617 & 523 & 38,713 & - & 4,170 & 387 & 30,772 & 一 \\
\hline Burn deaths & - & 530 & - & - & - & 388 & - & 一 \\
\hline \multicolumn{9}{|l|}{ Secondhand smoke deaths } \\
\hline Lung cancer & - & 1,130 & - & - & - & 1,930 & - & 一 \\
\hline Ischemic heart disease & - & 14,406 & - & - & - & 20,646 & - & 一 \\
\hline Total & - & 15,536 & - & - & - & 22,576 & - & 一 \\
\hline Total & - & 259,494 & $3,349,072$ & $61,938,270$ & - & 178,408 & $2,216,974$ & $30,579,815$ \\
\hline
\end{tabular}

* International Classification of Diseases, Tenth Revision.

${ }^{\dagger}$ Productivity loss estimates are in thousands of dollars.

smoking because costs associated with smoking-attributable health-care expenditures, smoking-related disability, employee absenteeism, and secondhand smoke-attributable disease morbidity and mortality were not included. Finally, the estimates do not account for the sampling variability in smoking prevalence estimates or in RRs.

Cigarette smoking continues to impose substantial health and financial costs on society. In 1998, smoking-attributable health-care expenditures were estimated at $\$ 75.5$ billion (2). During 1997-2001, these expenditures plus the productivity losses ( $\$ 92$ billion) exceeded $\$ 167$ billion per year. By comparison, investments in comprehensive, state-based tobacco prevention and control programs in 2002 were approximately 200 -fold smaller than those costs (9). Because investments in evidence-based prevention programs have produced larger and faster reductions in cigarette consumption (10), increased investments to the levels recommended by CDC are needed to achieve a greater health impact.

\section{References}

1. CDC. The health consequences of smoking: a report of the Surgeon General. Atlanta, GA: US Department of Health and Human Services, CDC; 2004

2. CDC. Smoking-attributable mortality, morbidity, and economic costs (SAMMEC): adult and maternal and child health software. Atlanta, GA: US Department of Health and Human Services, CDC; 2004.

3. Arias E. United States life tables, 2001. Nat Vital Stat Rep 2004;52. 
4. Haddix AC, Teutsch SM, Corso PS. Prevention effectiveness: a guide to decision analysis and economic evaluation. 2nd ed. New York, NY: Oxford University Press; 2003.

5. Hall JR. The U.S. smoking-material fire problem. Quincy, MA: National Fire Protection Association, Fire Analysis and Research Division; 2004

6. US Environmental Protection Agency. Respiratory health effects of passive smoking: lung cancer and other disorders. Washington, DC: US Environmental Protection Agency; 1992. EPA publication no. EPA/ 600/6-90/006

7. Steenland K. Passive smoking and risks of heart disease. JAMA 1992;267:94-9.

8. CDC. Smoking-attributable mortality, years of potential life lost, and economic costs-United States, 1995-1999. MMWR 2002; 51:300-3.

9. Taurus JA, Chaloupka FJ, Farrelly GA, et al. State tobacco control spending and youth smoking. Am J Public Health 2005;95:338-44.

10. Farrelly MC, Pechacek TF, Chaloupka FJ. The impact of tobacco control program expenditures on aggregate cigarette sales: 1981-2000. J Health Econ 2003;22:843-59.

\section{Heat-Related Mortality - Arizona, 1993-2002, and United States, 1979-2002}

Hyperthermia is the elevation of body temperature resulting from the body's inability to dissipate heat (1). Continued exposure to ambient heat close to body temperature $\left(98.6^{\circ} \mathrm{F}\right.$ $\left.\left[37.0^{\circ} \mathrm{C}\right]\right)$ contributes to a substantial number of deaths from hyperthermia, especially among elderly persons (2). To assess the health risk from hyperthermia, Arizona health practitioners and CDC researched cases of heat-related death and illness in Arizona, used U.S. death certificate data to summarize trends in heat-related deaths, and compared agespecific, heat-related death rates in Arizona with those in the United States overall. Findings indicated that, during 19792002, a total of 4,780 heat-related deaths in the United States were attributable to weather conditions and that, during 19932002, the incidence of such deaths was three to seven times greater in Arizona than in the United States overall. Public health agencies in communities affected by periods of extreme heat should educate populations at risk (e.g., persons aged $\geq 65$ years) and consider designing and implementing locationspecific heat response plans (HRPs).

\section{Case Reports - Arizona}

Case 1. In July 2001, a boy aged 14 years was participating in a youth boot camp west of Phoenix when he began hallucinating and eating dirt. He had been in direct sunlight for 1-5 hours in an outside temperature of $111^{\circ} \mathrm{F}\left(44^{\circ} \mathrm{C}\right)$. When the boy became unresponsive, camp supervisors placed him in a bathtub with a running shower. The tub drain reportedly became blocked with dirt and other material. The camp supervisors returned to find the boy with his face in the water. The supervisors telephoned 911, but the boy never regained consciousness and was pronounced dead later that night. The office of the medical examiner (ME) attributed the boy's death to complications of near-drowning and dehydration from heat exposure. The ME did not document a core body temperature.

Case 2. In August 2004, at 5:50 p.m, two sisters aged 2 and 4 years were found unresponsive in the locked family car by their mother in a Phoenix suburb. The children had been locked in the car for more than 15 minutes. Temperatures inside and outside the automobile were not recorded; however, high temperatures in the area on that day and at that time ranged from the mid- $90 \mathrm{~s}\left(-32^{\circ} \mathrm{C}\right)$ to $101^{\circ} \mathrm{F}\left(38^{\circ} \mathrm{C}\right)$. When emergency medical services (EMS) personnel arrived, both children were asystolic. During helicopter transport to the hospital, EMS personnel administered multiple doses of intraosseous epinephrine and atropine. At the emergency department $(\mathrm{ED})$, rectal temperatures were $106.4^{\circ} \mathrm{F}\left(41.3^{\circ} \mathrm{C}\right)$ for the younger girl and $105.0^{\circ} \mathrm{F}\left(40.6^{\circ} \mathrm{C}\right)$ for the older girl. Both children were pronounced dead within 10 minutes of arrival at the ED. The ME found severe cerebral edema in both children and declared hyperthermia as the cause of death.

Case 3. In May 2004, at approximately 4 p.m. in Phoenix, a man aged 35 years with a history of schizophrenia suddenly collapsed after working in a garden for 1 hour in $98^{\circ} \mathrm{F}\left(37^{\circ} \mathrm{C}\right)$ heat. EMS personnel found him unresponsive, with a heart rate of 170 beats per minute (bpm). At the ED, his rectal temperature was $105.4^{\circ} \mathrm{F}\left(40.8^{\circ} \mathrm{C}\right)$. Primary diagnosis was heat stroke with nonepileptic convulsions, with a secondary diagnosis of burn blisters with epidermal loss on limbs and trunk. The patient was intubated, rapidly cooled with fans and ice baths, and started on ceftriaxone and vancomycin; however, subsequent cultures and imaging studies were within normal limits. The man's hospital course was complicated by rhabdomyolysis, but he recovered and was discharged on the third day.

Case 4. In September 2004, at approximately 11 a.m. in a Phoenix suburb, a woman aged 59 years who had been riding her bicycle was found lying on the ground with altered mental status. The ambient temperature was $95^{\circ} \mathrm{F}\left(35^{\circ} \mathrm{C}\right)$. EMS personnel recorded a blood pressure of $130 / 72 \mathrm{~mm} / \mathrm{Hg}$, a heart rate of $174 \mathrm{bpm}$, and a respiratory rate of 28 breaths per minute. Serial examinations, multiple radiographs, and computerized tomography scans did not locate any trauma. The patient had an oral temperature of $101.4^{\circ} \mathrm{F}\left(38.8^{\circ} \mathrm{C}\right) 1$ hour after arriving at the ED. Primary diagnosis was heat stroke; schizophrenia (not otherwise specified), gastric hemorrhage, and acute renal failure were secondary diagnoses. The woman's mental status returned to baseline when she was externally 
cooled with water misters and fans. She was observed overnight and discharged the next day after improvement of her clinical status.

\section{Heat-Related Mortality - United States, 1979-2002}

During 1979-2002, the most recent years for which national data are available, 4,780 deaths were classified as heat related because of weather conditions.* Of the 4,686 (98\%) heat-related deaths attributed to weather for which age of the decedent was reported, $260(6 \%)$ occurred among children aged $<15$ years, 2,356 (50\%) among persons aged 15-64 years, and 2,070 (44\%) among persons aged $\geq 65$ years (3). During 1979-2002, heat waves with high mortality occurred in 1980 (St. Louis and Kansas City, Missouri), 1995 (Chicago, Illinois), and 1999 (Cincinnati, Ohio, and Chicago). During that period, the annual rate of heat-related deaths from weather conditions was highest among persons aged $\geq 65$ years (Figure 1 ).

\section{Heat-Related Mortality - Arizona, 1993-2002}

Arizona experiences intense and prolonged summer heat. Normal daily maximum temperature reaches $\geq 100^{\circ} \mathrm{F}\left(\geq 38^{\circ} \mathrm{C}\right)$ in early June and can remain at that level until mid-September (4). During 1993-2002, a total of 253 deaths in Arizona were attributable to heat exposure. During this period, Arizona had the highest average annual age-adjusted ${ }^{\dagger}$ rate of death from heat exposure (five deaths per million) among U.S. states. Within the state, the highest average annual age-adjusted death rates ( $>10$ per million population) occurred in the western counties of Mohave, La Paz, and Yuma. Combining data from the period 1993-2002, the rate of death from heat exposure in Arizona for persons aged $\geq 25$ years was three to seven times higher than that for the United States overall and ranged from two deaths per million persons aged 25-34 years to 42 deaths per million persons aged $\geq 85$ years (Figure 2 ).

Reported by: F LoVecchio, DO, JS Stapczynski, MD, Dept of Emergency Medicine, Maricopa Medical Center; J Hill, MD, Pediatric Intensive Care Unit, Banner Children's Hospital; AF Haffer, National Weather Svc, National Oceanic and Atmospheric Admin; JA Skindlov, Salt River Project, Phoenix; D Engelthaler, MSc, CMrela, PhD, Arizona Dept of Health Svcs. GE Luber, PhD, Div of Environmental Hazards and Health Effects, National Center for Environmental Health; $M$ Straetemans, PhD, Z Duprey, DVM, EIS officers, CDC.

\footnotetext{
*For the period 1979-1998, deaths were classified according to International Classification of Diseases, Ninth Revision (ICD-9), code E900.0, "due to weather conditions." For the period 1999-2002, deaths were classified according to ICD-10, code X30, "exposure to excessive natural heat."

${ }^{\dagger}$ Rates age-adjusted to the 2000 U.S. standard population.
}

FIGURE 1. Annual rate* of heat-related deaths attributed to weather conditions ${ }^{\dagger}$ or exposure to excessive natural heat, $\$$ by age group and year — United States, 1979-2002

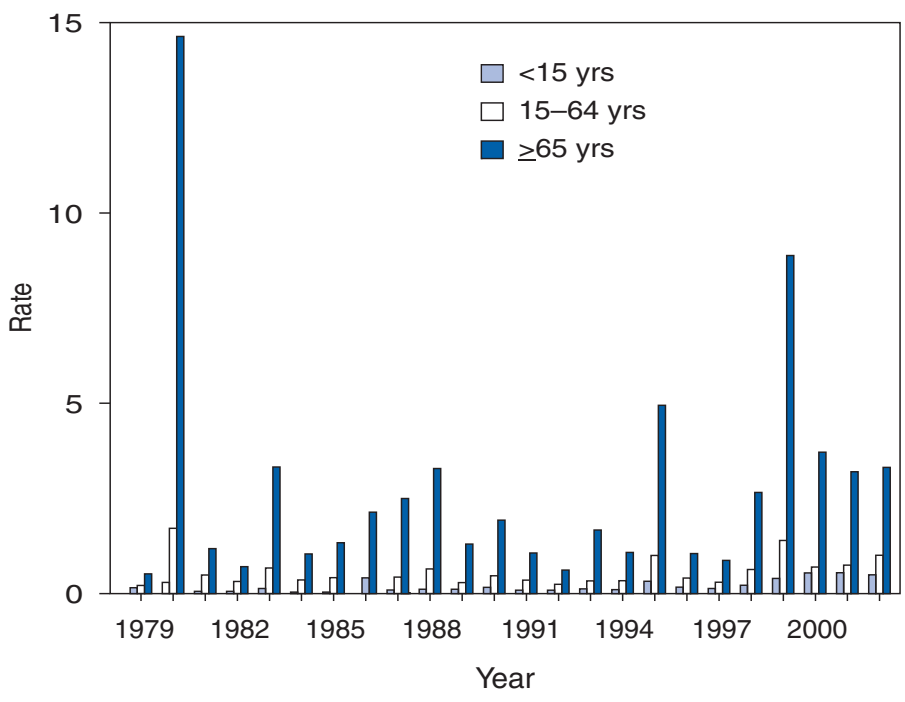

* Per 1,000,000 population

$\dagger$ International Classification of Diseases, Ninth Revision (ICD-9), code E900.0.

§ ICD-10, code X30.

FIGURE 2. Average annual rate* of heat-related deaths attributed to weather conditions ${ }^{\dagger}$ or exposure to excessive natural heat, $\$$ by age group - United States, 1979-2002

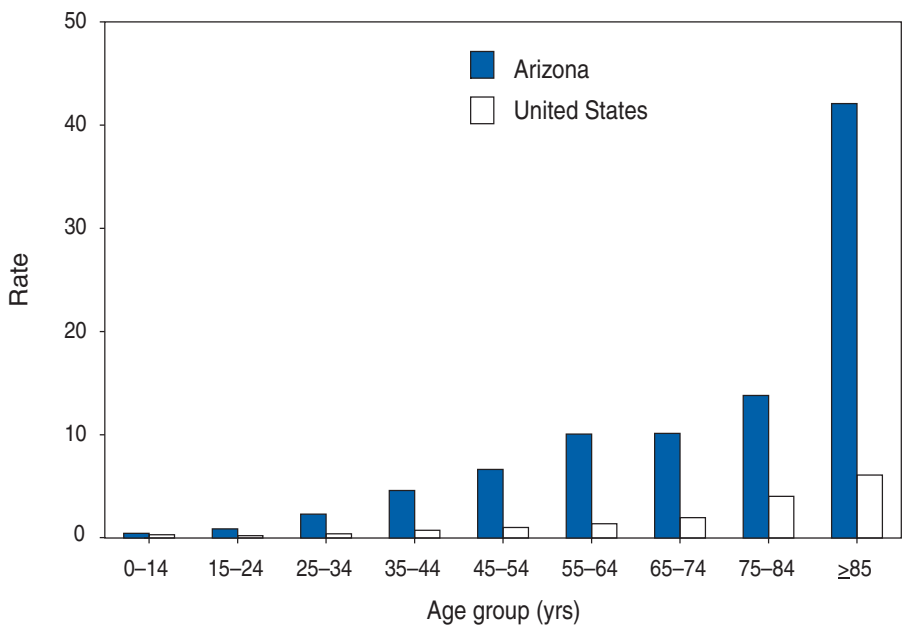

*Per $1,000,000$ population

$\dagger$ International Classification of Diseases, Ninth Revision (ICD-9), code E900.0.

$\S_{\text {ICD-10, code X30. }}$

Editorial Note: The Arizona cases described in this report highlight the spectrum of disease caused by exposure to excessive heat. Exposure to prolonged periods of high temperature can cause heat-related illnesses, including heat cramps, heat 
syncope, heat exhaustion, heat stroke, and death (5). Heat exhaustion is the most common heat-related illness (G). Signs and symptoms include intense thirst, heavy sweating, weakness, paleness, discomfort, anxiety, dizziness, fatigue, fainting, nausea or vomiting, and headache. Core body temperature can be normal, below normal, or slightly elevated, and the skin can be cool and moist $(5,7,8)$. If unrecognized and untreated, these mild to moderate signs and symptoms can progress to heat stroke $(\sigma)$, a severe illness clinically defined as core body temperature $\geq 105.0^{\circ} \mathrm{F}\left(\geq 40.6^{\circ} \mathrm{C}\right)$, accompanied by hot, dry skin and central nervous system abnormalities, such as delirium, convulsions, or coma $(5,7,8)$.

To prevent heat-related illness and death, public health agencies should identify susceptible populations and risk behaviors. Children, elderly persons, and persons without access to air conditioning are at increased risk for heat-related illness and death. In addition, persons with chronic mental disorders or cardiopulmonary disease and those receiving medications that interfere with salt and water balance, such as diuretics, anticholergic agents, and tranquilizers that impair sweating, are at greater risk for heat-related illness and death. Drinking alcoholic beverages, ingesting illicit drugs (e.g., cocaine or amphetamines), and participating in strenuous outdoor physical activities (e.g., sports or manual labor) in hot weather also are risk behaviors associated with heat-related illness $(7,9,10)$.

Periodic heat waves highlight the need for public health interventions to prevent excess morbidity and mortality; written HRPs are central to those interventions. HRPs detail actions that local government agencies and nongovernment organizations can take in the event of a forecast of extremely hot weather to reduce heat-related mortality (Box).

All heat-related deaths and illnesses are preventable. In hot weather, persons can take precautions, including rescheduling strenuous outdoor activities to cooler times of the day, reducing the level of physical activity, drinking additional water, wearing lightweight and light-colored clothing, and increasing the amount of time spent in air-conditioned environments (7). Indoors, persons can prevent sunlight from coming through windows and minimize cooking; sprinkling water on clothing also can reduce heat stress. Parents should never leave young children in parked cars and should keep cars locked when not in use. Relatives, neighbors, and caretakers of persons at risk for heat-related illness and death (e.g., elderly, disabled, and homebound persons) should frequently check on these persons, recognize symptoms of heat-related morbidity, and take appropriate action (5).

\section{References}

1. Blum FC. Fever [Chapter 11]. In: Marx J, Hockberger R, Walls R, eds. Rosen's emergency medicine: concepts and clinical practice. 5th ed. St. Louis, MO: CV Mosby, Inc; 2002:115.
BOX. Criteria for development of an effective heat response plan (HRP)

- Identify a lead agency and other participating agencies and nongovernment organizations, describing roles and responsibilities in detail.

- Review plans annually, before onset of warm weather, to review response protocols and confirm participation of lead personnel.

- Identify activation and deactivation thresholds for the HRP by using community-specific factors affecting mortality (e.g., extremes in daytime high and nighttime low temperatures and deviation from local norms).

- Before a heat emergency, use preexisting communication plans and public education tools to define a clear communications strategy and pathway from the lead agency to first responders, the public, and the media.

- Define risk factors, populations at high risk, and methods to reach them (e.g., daily checks on the elderly by social service agency personnel and provision for transportation to air-conditioned public centers).

- Establish a method to evaluate and revise the HRP, including post-emergency meetings with participating agencies to review response activities, activation and deactivation thresholds, communication plans, outreach activities, and the association between weather data and heat-related morbidity and mortality.

SOURCE: Bernard SM, McGeehin MA. Municipal heat wave response plans. Am J Public Health 2004;94:1520-2.

2. Semenza JC, Rubin $\mathrm{CH}$, Falter KH, et al. Risk factors for heat-related mortality during the July 1995 heat wave in Chicago. N Engl J Med 1996;35:84-90.

3. CDC. Compressed mortality file 2004. Hyattsville, MD: US Department of Health and Human Services, CDC, National Center for Health Statistics; 2004.

4. Western Regional Climate Center. Western U.S. climate historical summaries. Reno, NV: Western Regional Climate Center. Available at http://www.wrcc.dri.edu/climsum.html.

5. Kilbourne EM. Heat waves and hot environments. In: Noji EK, ed. The public health consequences of disasters. New York, NY: Oxford University Press; 1997:245-69.

6. Lugo-Amador NM, Rothenhaus T, Moyer P. Heat-related illness. Emerg Med Clin North Am 2004;22:315-27.

7. Bouchama A, Knochel JP. Heat stroke. N Engl J Med 2002;346: 1978-88.

8. CDC. Extreme heat. Atlanta, GA: US Department of Health and Human Services, CDC; 1996. Available at http://www.cdc.gov/nceh/ hsb/extremeheat.

9. Bytomski JR, Squire DL. Heat illness in children. Curr Sports Med Rep 2003;2:320-4.

10. Donaldson GC, Keatinge WR, Saunders RD. Cardiovascular responses to heat stress and their adverse consequences in healthy and vulnerable human populations. Int J Hyperthermia 2003;19:225-35. 


\section{Update: Influenza Activity - United States and Worldwide, 2004-05 Season}

During the 2004-05 influenza season, influenza A (H1), ${ }^{*}$ A (H3N2), and B viruses cocirculated worldwide, and influenza A (H3N2) viruses predominated. In addition, several Asian countries continued to report widespread outbreaks of avian influenza A (H5N1) among poultry; in Vietnam, Thailand, and Cambodia, these outbreaks were associated with severe illnesses and deaths among humans. In the United States, the 2004-05 influenza season peaked in February, was moderate, and was associated predominantly with influenza $\mathrm{A}$ (H3N2) viruses. This report summarizes influenza activity in the United States and worldwide during the 2004-05 influenza season.

\section{United States Influenza Activity}

Influenza activity occurred at low levels from October to mid-December, steadily increased during January, and peaked in mid-February. Influenza A (H3N2) viruses predominated overall, but influenza $B$ viruses were more frequently identified than influenza A viruses during late March through May. A small number of A (H1) viruses were also identified.

\section{Viral Surveillance}

During October 3, 2004-May 21, 2005, World Health Organization (WHO) and National Respiratory and Enteric Virus Surveillance System (NREVSS) collaborating laboratories in the United States tested 157,759 respiratory specimens for influenza viruses (Figure 1); 23,549 (14.9\%) were positive.

Among the 23,549 identified influenza viruses, 17,750 (75.4\%) were influenza A viruses, and 5,799 (24.6\%) were influenza B viruses. A total of 5,819 (32.8\%) of the 17,750 influenza A viruses were subtyped; 5,801 (99.7\%) were influenza $A(\mathrm{H} 3 \mathrm{~N} 2)$, and $18(0.3 \%)$ were influenza $\mathrm{A}(\mathrm{H} 1)$ viruses. The proportion of specimens testing positive for influenza first exceeded 10\% during the week ending December 25, 2004 (week 51), peaked at $27.0 \%$ during the week ending February 5, 2005 (week 5), and declined to $<10 \%$ during the week ending April 9, 2005 (week 14). The peak percentage of specimens testing positive for influenza during the previous three seasons had ranged from $24.9 \%$ to $34.7 \%$ and peaked during late November to late February ( 1 ; CDC, unpublished data, 2005).

\footnotetext{
*Includes both the A (H1N1) and A (H1N2) influenza virus types.
}

FIGURE 1. Number* and percentage of respiratory specimens testing positive for influenza reported by World Health Organization and National Respiratory and Enteric Virus Surveillance System collaborating laboratories, by week United States, 2004-05 influenza season ${ }^{\dagger}$

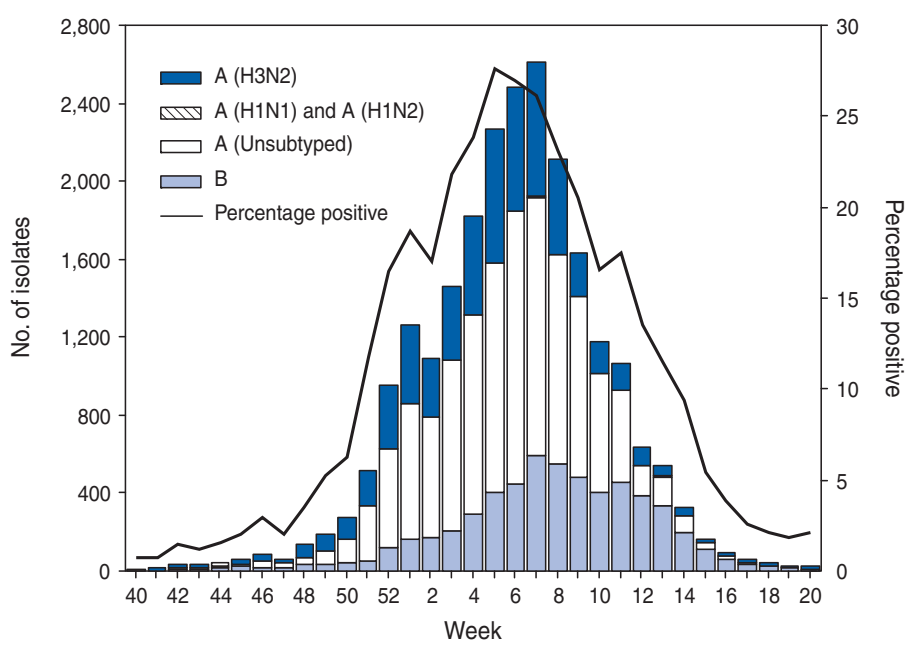

${ }^{*} \mathrm{~N}=23,549$

${ }^{\dagger}$ As of June 18, 2005.

\section{Antigenic Characterization}

CDC antigenically characterized 1,075 influenza viruses collected by U.S. laboratories since October 1, 2004: a total of 11 influenza $A$ (H1N1) viruses, 709 influenza A (H3N2) viruses, and 355 influenza $B$ viruses. All 11 of the influenza $A$ (H1N1) viruses were similar antigenically to $\mathrm{A} / \mathrm{New}$ Caledonia/20/99, the 2004-05 and 2005-06 vaccine component. A total of 156 (22.0\%) of the 709 influenza A $(\mathrm{H} 3 \mathrm{~N} 2)$ isolates were characterized as antigenically similar to A/Wyoming/3/2003, which is the A/Fujian/411/2002-like (H3N2) component of the 2004-05 influenza vaccine, and 553 (78.0\%) were characterized as A/California/7/2004-like. An A/California/07/2004-like virus was recommended as the $\mathrm{H} 3$ component for the 2005-06 Northern Hemisphere vaccine.

Influenza $\mathrm{B}$ viruses circulating worldwide can be divided into two antigenically distinct lineages: B/Yamagata/16/88 and B/Victoria/2/87. The type-B component of the 2004-05 and 2005-06 influenza vaccines (B/Shanghai/361/2002-like) belongs to the B/Yamagata lineage. A total of 264 (74.4\%) of the influenza B viruses characterized in the 2004-05 season belong to the B/Yamagata/16/88 lineage. Of these, 219 (83.0\%) were B/Shanghai/361/2002-like, and 45 (17.0\%) had reduced titers to ferret antisera produced against $\mathrm{B} / \mathrm{Shanghai} /$ $361 / 2002$. Ninety-one (25.6\%) influenza B viruses belong to the $\mathrm{B} /$ Victoria/2/87 lineage. 


\section{Influenza-Like Illness (ILI)† Surveillance}

The weekly percentage of patient visits to U.S. influenza sentinel providers for ILI first exceeded the national baseline of $2.5 \% \$$ during the week ending January 1,2005 , and again for 13 consecutive weeks during the weeks ending January 15-March 26, 2005. ILI peaked at 5.4\% during the week ending February 19, 2005. During the previous three influenza seasons, the peak percentage of patient visits for ILI ranged from $3.2 \%$ to $7.6 \%$ and occurred during late December through early February (1; CDC, unpublished data, 2005).

\section{State-Specific Activity Levels}

Influenza activity, as reported by state and territorial epidemiologists, peaked during the week ending February 19, 2005 (week 7), when 30 states reported widespread influenza activity and 13 states reported regional activity. $\mathrm{A}$ total of 42 states and New York City reported widespread influenza activity for at least 1 week. No states reported widespread, regional, or local influenza activity during the weeks ending May 7-21, 2005 (weeks 18-20). The peak number of states reporting widespread or regional activity during the previous three seasons ranged from 35 to 50 states (1; CDC, unpublished data, 2005).

\section{Influenza-Associated Pediatric Hospitalizations}

Laboratory-confirmed, influenza-associated, pediatric hospitalizations are monitored in two population-based surveillance networks: the Emerging Infections Program (EIP) and the New Vaccine Surveillance Network (NVSN). During October 1, 2004-April 30, 2005, ${ }^{* *}$ the preliminary influenzaassociated hospitalization rates for children aged 0-4 years reported by NVSN and EIP were 7.0 and 3.1 per 10,000 , respectively. EIP also monitors hospitalizations in children aged

\footnotetext{
${ }^{\dagger}$ Defined as temperature of $\geq 100.0^{\circ} \mathrm{F}\left(\geq 37.8^{\circ} \mathrm{C}\right)$ and either cough or sore throat in the absence of a known cause other than influenza.

$\$$ The national baseline was calculated as the mean percentage of patient visits for ILI during non-influenza weeks plus two standard deviations. Wide variability in regional data precludes calculating region-specific baselines and makes it inappropriate to apply the national baseline to regional data. National and regional percentages of patient visits for ILI are weighted on the basis of state population.

'Levels of activity are 1) no activity; 2) sporadic: isolated laboratory-confirmed influenza cases or laboratory-confirmed outbreak in one institution, with no increase in activity; 3) local: increased ILI in one region, or at least two institutional outbreaks (ILI or laboratory-confirmed influenza) in one region; virus activity no greater than sporadic in other regions; 4) regional: increased ILI activity or outbreaks (ILI or laboratory-confirmed influenza) in at least two but fewer than half of the regions in the state; and 5) widespread: increased ILI activity or outbreaks (ILI or laboratory-confirmed influenza) in at least half the regions in the state.

** Active prospective surveillance in EIP and NVSN for the 2004-05 influenza season ended as of April 30, 2005.
}

5-17 years; the preliminary influenza-associated hospitalization rate for this age group was 0.6 per 10,000 . The overall hospitalization rate reported by EIP for children aged 0-17 years was 1.3 per 10,000 .

During 2000-2004, the end-of-season hospitalization rate for NVSN ranged from 3.7 (2002-03) to 12.0 (2003-04) per 10,000 children. The 2003-04 end-of-season hospitalization rate for EIP was 8.9 per 10,000 children aged $0-4$ years and 0.8 per 10,000 for children aged $5-17$ years. The difference in rates between NVSN and EIP is likely attributable to different case-finding methods and the different populations monitored. ${ }^{\dagger \dagger}$

\section{Pneumonia and Influenza-Related Mortality}

As measured by the 122 Cities Mortality Reporting System, the percentage of deaths in the United States attributed to pneumonia and influenza (P\&I) exceeded the epidemic threshold ${ }^{\$ \S}$ during 8 consecutive weeks ending February 14 April 9, 2005, and peaked at 8.9\% during the week ending March 5, 2005 (Figure 2). The percentage of P\&I deaths remained below the threshold through the weeks ending April 30-May 21, 2005. During the previous three influenza seasons, the peak percentage of P\&I deaths ranged from $8.5 \%$ to 10.4\% (1; CDC, unpublished data, 2005).

\section{Influenza-Associated Pediatric Mortality}

In October 2004, pediatric deaths (i.e., deaths in children aged $<18$ years) associated with laboratory-confirmed influenza infection became a nationally notifiable condition. For the 2004-05 influenza season, 36 pediatric deaths have been reported to CDC from 16 states (California, Colorado, Florida, Georgia, Iowa, Maine, Maryland, Massachusetts, Michigan, Mississippi, Nevada, New Jersey, New York, Ohio, Pennsylvania, and Vermont) and New York City; all deaths were reported during January-June 2005.

\footnotetext{
†† NVSN provides population-based estimates of laboratory-confirmed influenza hospitalization rates in children aged $<5$ years admitted to NVSN hospitals with fever or respiratory symptoms. Children are prospectively enrolled, and respiratory samples are collected and tested by viral culture and reverse transcriptase-polymerase chain reaction (PCR). EIP conducts surveillance for laboratory-confirmed, influenza-related hospitalizations in person aged $<18$ years. Hospital laboratory and admission databases and infection-control logs are reviewed to identify children with a positive influenza test result (i.e., culture, direct or indirect fluorescent antibody assays, PCR, or a rapid test) from testing conducted as a part of their routine care.

$\$ \$$ The expected seasonal baseline proportion of P\&I deaths reported by the 122 Cities Mortality Reporting System is projected by using a robust regression procedure in which a periodic regression model is applied to the observed percentage of deaths from P\&I during the previous 5 years. The epidemic threshold is 1.654 standard deviations above the seasonal baseline.
} 
FIGURE 2. Percentage of all deaths attributed to pneumonia and influenza mortality, by week and year - 122 U.S. cities, week ending May 21, 2005

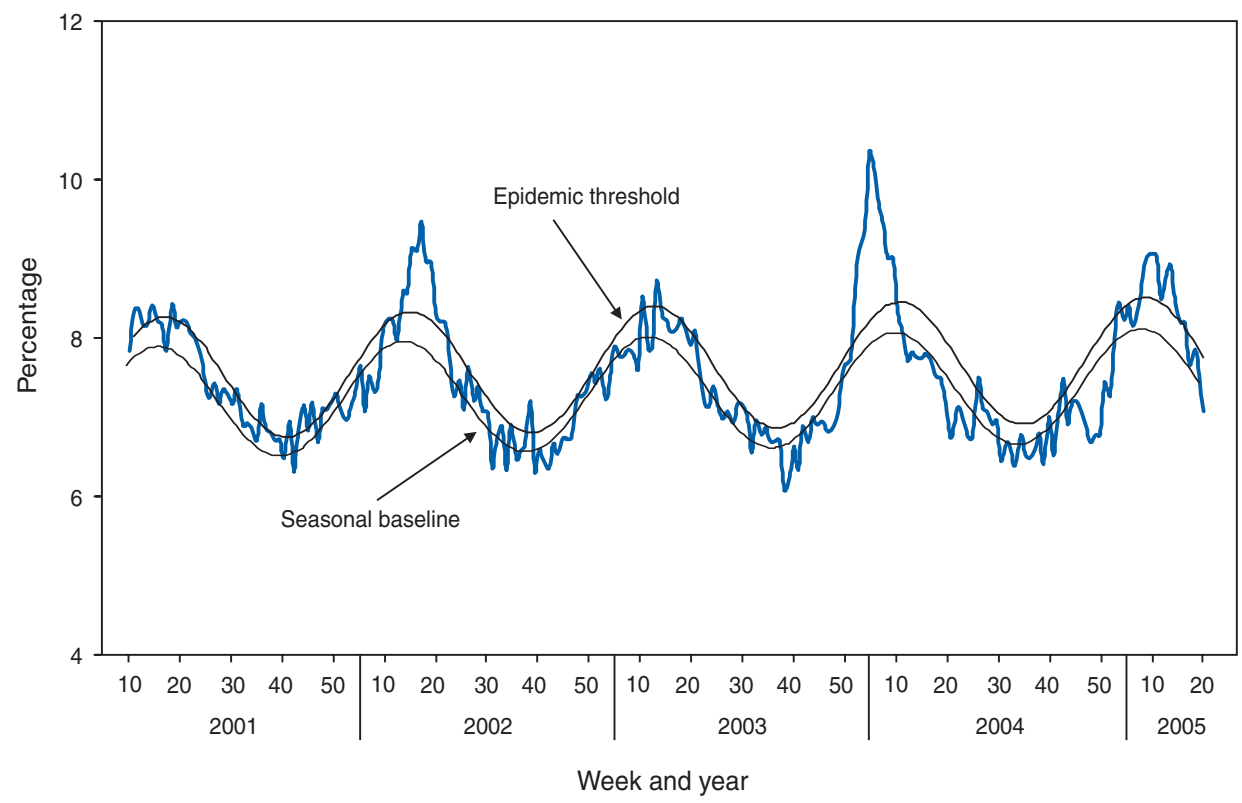

Denmark, France, Germany, Greece, Ireland, Italy, Latvia, Norway, Poland, Portugal, Romania, Russian Federation, Slovakia, Sweden, Switzerland, Turkey, Ukraine, and the United Kingdom), and South America (Brazil and Peru).

Influenza $B$ viruses were reported in association with outbreaks in Asia (China, Hong Kong, Japan, and Taiwan) and Europe (Denmark, Ireland, and the Netherlands). Influenza B viruses also were isolated in Africa (Egypt, Madagascar, Morocco, Senegal, South Africa, and Tunisia), Asia (Bangladesh, India, Indonesia, Israel, Malaysia, South Korea, Singapore, and Thailand), the Caribbean (Jamaica and Saint Lucia), Europe (Austria, Belarus, Belgium, Czech Republic, Finland, France, Germany, Greece, Iceland, Italy, Latvia, Norway, Portugal, Romania,

\section{Worldwide Influenza Activity}

During October 2004-May 2005, influenza A viruses circulated widely worldwide. Influenza A (H3N2) viruses predominated in most countries, whereas influenza $\mathrm{A}(\mathrm{H} 1)$ and $\mathrm{B}$ viruses circulated at low levels in most parts of the world. Influenza A (H3N2) viruses predominated and were associated with outbreaks in Asia (Hong Kong, Indonesia, Israel, and South Korea), Europe (Belgium, Finland, France, Germany, Italy, Latvia, Norway, Portugal, Romania, the Russian Federation, Spain, Sweden, Switzerland, Turkey, Ukraine, and the United Kingdom), and North America (Canada). Influenza A (H3N2) viruses also were reported in Africa (Egypt, Madagascar, Morocco, Senegal, South Africa, and Tunisia), Asia (China, India, Iraq, Iran, Japan, Kyrgyzstan, Malaysia, the Philippines, Singapore, Taiwan, and Thailand), Europe (Austria, Belarus, Bulgaria, Czech Republic, Denmark, Greece, Hungary, Iceland, Ireland, the Netherlands, Poland, Serbia and Montenegro, and Slovenia), South America and the Caribbean (Argentina, Brazil, Chile, Dominica, Guyana, Peru, Saint Lucia, and Venezuela), North America (Canada and Mexico), and Oceania (Australia, Guam, New Caledonia, and New Zealand).

Influenza A ( $\mathrm{H} 1)$ viruses circulated at low levels in most parts of the world. Influenza A (H1) viruses were isolated in Africa (Senegal, South Africa, and Tunisia), Asia (China, Hong Kong, Indonesia, Iran, Israel, Japan, Kazakhstan, Kyrgyzstan, Malaysia, Singapore, South Korea, Taiwan, and Thailand), Europe (Austria, Belgium, Bulgaria, Czech Republic,
Russia, Spain, Sweden, Switzerland, Turkey, Ukraine, and the United Kingdom), South America (Argentina, Brazil, Chile, Colombia, Guyana, Paraguay, Peru, and Uruguay), North America (Canada and Mexico), and Oceania (Australia, New Caledonia, and New Zealand).

\section{Human Infections with Avian Influenza A (H5N1) Viruses}

During January 2004-June 28, 2005, a total of 108 human cases of avian influenza A (H5N1) infection resulting in 54 deaths were reported in Vietnam (87 cases and 38 deaths), Thailand (17 cases and 12 deaths), and Cambodia (four cases and four deaths) (2). From mid-December 2004 through June 28,2005 , a total of 60 cases (18 deaths) were reported in Vietnam, and four cases (four deaths) were reported in Cambodia (2).

Reported by: WHO Collaborating Center for Surveillance, Epidemiology, and Control of Influenza. R Dhara, MPH, K Teates, MPH, L Brammer, MPH, T Wallis, MS, A Postema, MPH, T Uyeki, MD, A Klimov, PhD, K Fukuda, MD, N Cox, PhD, Div of Viral and Rickettsial Diseases, National Center for Infectious Diseases, CDC.

Editorial Note: During the 2004-05 influenza season, influenza A (H3N2) viruses predominated in most countries in Asia, Europe, and North America, but influenza A (H1) and $B$ viruses were also identified. In the United States, influenza activity peaked in February and was less severe than during the previous season. 
Human infections with avian influenza A (H5N1) viruses continue to be identified in Southeast Asia. To date, the majority of cases have been associated with direct exposure to $\mathrm{A}$ (H5N1)-infected poultry. Probable, limited, person-toperson transmission of A (H5N1) viruses during 2004 occurred in Thailand (3) and is one of several possible explanations for the observed increase in clusters of A (H5N1) cases in northern Vietnam during 2005 (4). Limited, person-toperson transmission of A ( $\mathrm{H} 5 \mathrm{~N} 1)$ was also identified during the 1997 outbreak in Hong Kong (5). However, efficient, sustained, person-to-person transmission of influenza A (H5N1) viruses has not been reported to date. Genetic analysis of influenza A (H5N1) viruses isolated from humans in 2004 and 2005 revealed that all genes were of avian origin.

$\mathrm{CDC}$ continues to recommend enhanced surveillance for influenza A (H5N1) infection among travelers with severe unexplained respiratory illness returning from A (H5N1)affected countries. Additional information is available at http:// www.phppo.cdc.gov/HAN/ArchiveSys/ViewMsgV.asp? AlertNum=00221.

Additional information on influenza, including avian influenza, is available at http://www.cdc.gov/flu. Updates on human infections with avian influenza are available from the World Health Organization at http://www.who.int/csr/disease/ avian_influenza/en.

\section{Acknowledgments}

This report is based on data contributed by participating state and territorial health departments and state public health laboratories, WHO collaborating laboratories, National Respiratory and Enteric Virus Surveillance System collaborating laboratories, the U.S. Influenza Sentinel Provider Surveillance System, the New Vaccine Surveillance Network, the Emerging Infections Program, and the 122 Cities Mortality Reporting System. WHO National Influenza Centers, WHO Global Influenza Programme, Geneva, Switzerland. I Gust, MD, A Hampson, WHO Collaborating Center for Reference and Research on Influenza, Parkville, Australia. A Hay, $\mathrm{PhD}$, WHO Collaborating Center for Reference and Research on Influenza, National Institute for Medical Research, London, England. M Tashiro, MD, WHO Collaborating Center for Reference and Research on Influenza, National Institute of Infectious Diseases, Tokyo, Japan. Bur of Epidemiology and Field Epidemiology Training Program, Thai Ministry of Public Health. National Center for Public Health Informatics; National Immunization Program, CDC.

\section{References}

1. CDC. Update: influenza activity_-United States and worldwide, 200304 season, and composition of the 2004-05 vaccine. MMWR 2004; 53:547-52.

2. World Health Organization. Cumulative number of confirmed human cases of avian influenza $\mathrm{A} /(\mathrm{H} 5 \mathrm{~N} 1)$ reported to WHO, 28 June 2005. Geneva, Switzerland: World Health Organization; 2005. Available at http://www.who.int/csr/disease/avian_influenza/country/cases_ table_2005_06_28/en/index.html

3. Ungchusak K, Auewarakul P, Dowell SF, et al. Probable person-toperson transmission of avian influenza A (H5N1). N Engl J Med 2005;352:333-40.

4. World Health Organization. WHO intercountry consultation. Influenza A/H5N1 in humans in Asia. Manila, Philippines, May 6-7, 2005. Geneva, Switzerland: World Health Organization; 2005. Available at http://www.who.int/csr/resources/publications/influenza/WHO_ CDS_CSR_GIP_2005_7_04.pdf.

5. Bridges CB, Katz JM, Seto WH, et al. Risk of influenza A (H5N1) infection among health-care workers exposed to patients with influenza A (H5N1), Hong Kong. J Infect Dis 2000;181:344-8.

\section{Notice to Readers}

\section{Beginning and Intermediate/Advanced Courses in Epi Info}

Emory University's Rollins School of Public Health and CDC's Office of Workforce and Career Development will cosponsor Epi Info training August 10-12, 2005, for beginning level students and August 15-17, 2005, for intermediate/advanced level students. Courses will be held at Emory University; tuition is charged.

These courses are designed for practitioners of epidemiology and computing who wish to develop software applications using Epi Info for Windows. The beginning level course will cover MakeView, Analysis, Enter, Epi Map and Epi Report. The intermediate/advanced level course will cover importing and converting other data formats; creating relational databases; advanced check-coding and use of Epi Info functions; advanced analysis (e.g., linear regression, logistic regression, Kaplan-Meier method, Cox proportional hazards, complex sample frequencies, tables and means); special topics regarding Epi Map and Epi Report; and issues related to students' own projects.

Additional information and applications are available from Emory University, Rollins School of Public Health, International Health Department, 1518 Clifton Road, N.E., Room 746, Atlanta, Georgia, 30322; fax 404-727-4590; website http://www.sph.emory.edu/epicourses; e-mailpvaleri@sph.emory.edu. 


\section{QuickStats}

FROM THE NATIONAL CENTER FOR HEALTH STATISTICS

Percentage of Adults* Who Reported Being Deaf or Having a Lot of Trouble Hearing Without a Hearing Aid, by Sex and Age Group - United States, 2003

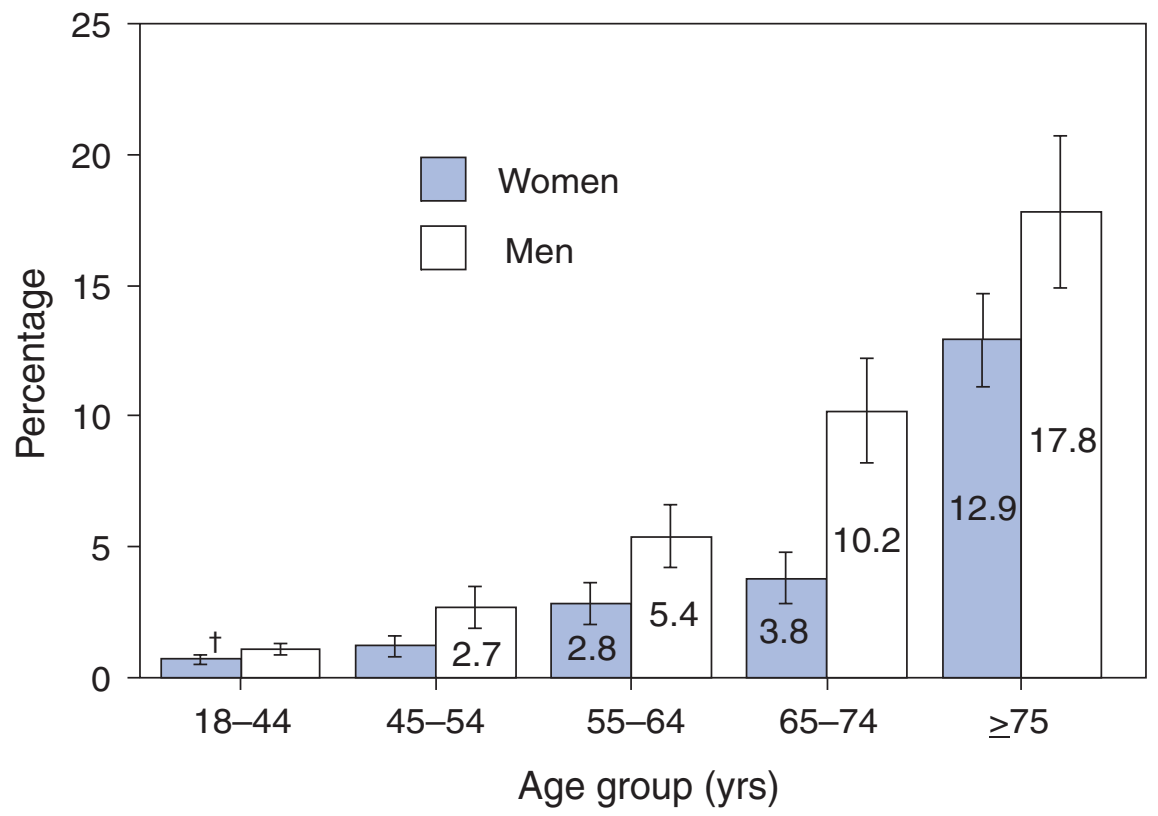

* The civilian, noninstitutionalized population aged $\geq 18$ years.

† $95 \%$ confidence interval.

In 2003, the percentage of adults aged $\geq 18$ years who reported being deaf or having a lot of trouble hearing increased with age, from $1 \%$ in persons aged $18-44$ years to $15 \%$ in persons aged $\geq 75$ years. In every age group, more men than women reported hearing limitations; among persons aged 65-74 years, men were more than twice as likely as women to have hearing limitations.

SOURCE: National Health Interview Survey, 2003. Available at http://www.cdc.gov/nchs/nhis.htm. 


\section{Notice to Readers}

\section{Satellite Broadcast on Immunization Update 2005}

CDC's National Immunization Program and the Public Health Training Network will present a live satellite broadcast, "Immunization Update 2005," on July 28, 2005, from 9:00 to 11:30 a.m. EDT, and a rebroadcast of the same program that day from 12:00 to 2:30 p.m. EDT. Both broadcasts will include a live question-and-answer session, during which participants nationwide can interact with course instructors via toll-free telephone lines.

This program is intended for physicians, nurses, nurse practitioners, physician assistants, pharmacists, residents, medical and nursing students, and their colleagues who either administer vaccinations or set policy in the workplace. Anticipated topics include recommendations for influenza vaccination and an update of the influenza vaccine supply, meningococcal conjugate vaccine, acellular pertussis vaccine for adolescents, and revised varicella vaccination recommendations. Continuing education credit (2.5 hours of instruction) will be offered for various professions.

The program can be viewed via live webcast and will also be available for viewing for 30 days after the broadcast at http:// www.phppo.cdc.gov/phtn/webcast/immup2005. Information about the satellite broadcast, webcast, and continuing education registration is available at http://www.phppo.cdc.gov/ phtn/immup2005/default.asp. Information on locations for viewing the satellite broadcast can be obtained from state distance-learning coordinators (http://www.cdc.gov/nip/ed/ coordinators.htm). 
FIGURE I. Selected notifiable disease reports, United States, comparison of provisional 4-week totals June 25, 2005, with historical data

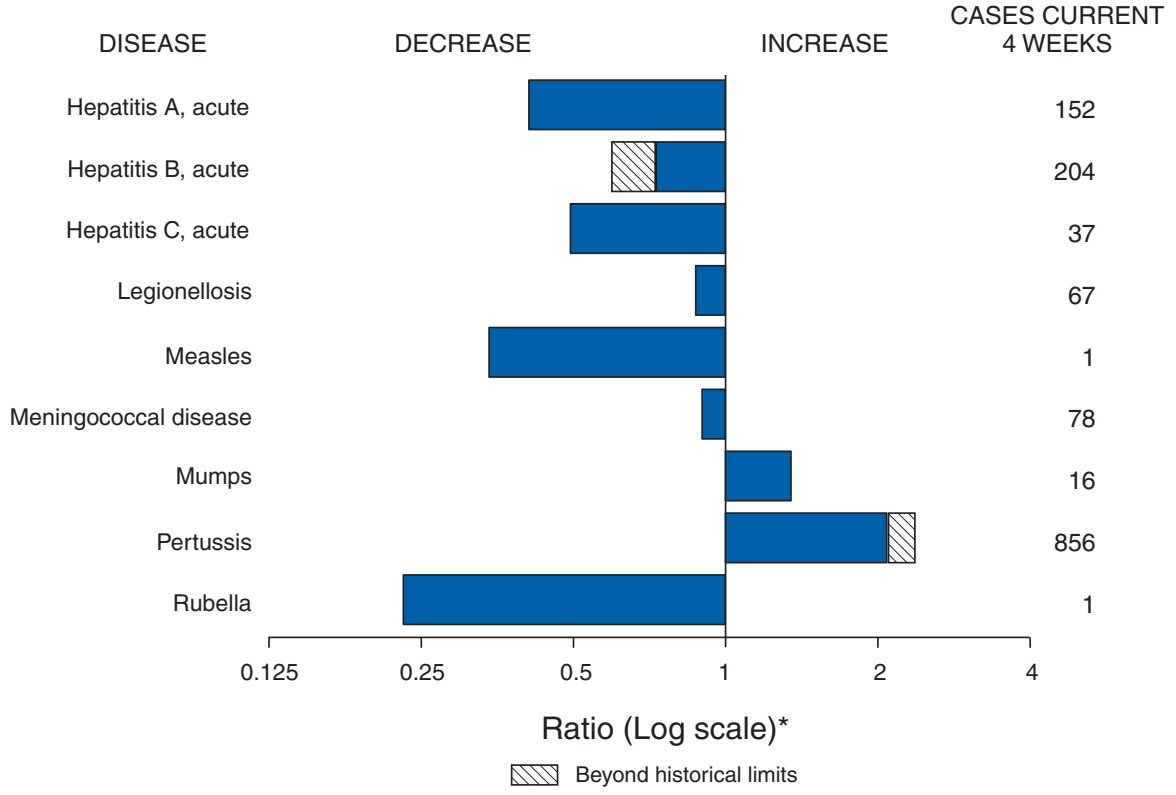

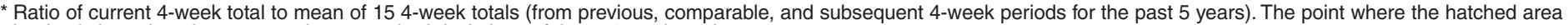
begins is based on the mean and two standard deviations of these 4-week totals.

TABLE I. Summary of provisional cases of selected notifiable diseases, United States, cumulative, week ending June 25, 2005 (25th Week)

\begin{tabular}{|c|c|c|c|c|c|}
\hline Disease & $\begin{array}{l}\text { Cum. } \\
2005\end{array}$ & $\begin{array}{l}\text { Cum. } \\
2004\end{array}$ & Disease & $\begin{array}{l}\text { Cum. } \\
2005\end{array}$ & $\begin{array}{l}\text { Cum. } \\
2004\end{array}$ \\
\hline Anthrax & - & - & Hemolytic uremic syndrome, postdiarrheal ${ }^{\dagger}$ & 61 & 50 \\
\hline Botulism: & & & HIV infection, pediatric ${ }^{\dagger \uparrow}$ & 150 & 170 \\
\hline foodborne & 6 & 6 & Influenza-associated pediatric mortality ${ }^{\dagger \star \star}$ & 36 & - \\
\hline infant & 28 & 37 & Measles & $22^{\dagger+}$ & 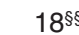 \\
\hline other (wound \& unspecified) & 12 & 5 & Mumps & 125 & 106 \\
\hline Brucellosis & 40 & 45 & Plague & 2 & - \\
\hline Chancroid & 11 & 23 & Poliomyelitis, paralytic & - & - \\
\hline Cholera & 1 & 4 & Psittacosis $^{\dagger}$ & 9 & 6 \\
\hline Cyclosporiasis $^{\dagger}$ & 525 & 100 & Q fever ${ }^{\dagger}$ & 44 & 33 \\
\hline Diphtheria & - & - & Rabies, human & 1 & - \\
\hline Domestic arboviral diseases & & & Rubella & 6 & 9 \\
\hline (neuroinvasive \& non-neuroinvasive): & - & - & Rubella, congenital syndrome & 1 & - \\
\hline California serogroup ${ }^{\dagger \S}$ & - & 7 & $\mathrm{SARS}^{\dagger * *}$ & - & - \\
\hline eastern equine ${ }^{\dagger \S}$ & - & - & Smallpox ${ }^{\dagger}$ & - & - \\
\hline Powassan ${ }^{\dagger \S}$ & - & - & Staphylococcus aureus: & & \\
\hline St. Louis ${ }^{\dagger \S}$ & - & 1 & Vancomycin-intermediate $(\mathrm{VISA})^{\dagger}$ & - & - \\
\hline western equine ${ }^{\dagger \S}$ & - & - & Vancomycin-resistant (VRSA) ${ }^{\dagger}$ & - & 1 \\
\hline Ehrlichiosis: & - & - & Streptococcal toxic-shock syndrome ${ }^{\dagger}$ & 78 & 87 \\
\hline human granulocytic (HGE) ${ }^{\dagger}$ & 72 & 87 & Tetanus & 10 & 9 \\
\hline human monocytic $(\mathrm{HME})^{\dagger}$ & 52 & 62 & Toxic-shock syndrome & 46 & 43 \\
\hline human, other and unspecified ${ }^{\dagger}$ & 15 & 11 & Trichinellosis $9 \pi$ & 5 & - \\
\hline Hansen disease $^{\dagger}$ & 35 & 48 & Tularemia $^{\dagger}$ & 38 & 31 \\
\hline Hantavirus pulmonary syndrome ${ }^{\dagger}$ & 8 & 8 & Yellow fever & - & - \\
\hline
\end{tabular}

二: No reported cases.

* Incidence data for reporting years 2004 and 2005 are provisional and cumulative (year-to-date).

Not notifiable in all states.

$\S$ Updated weekly from reports to the Division of Vector-Borne Infectious Diseases, National Center for Infectious Diseases (ArboNet Surveillance).

" Updated monthly from reports to the Division of HIV/AIDS Prevention, National Center for HIV, STD, and TB Prevention. Last update May $29,2005$.

** Updated weekly from reports to the Division of Viral and Rickettsial Diseases, National Center for Infectious Diseases.

†† $\mathrm{O} 22$ cases reported, 14 were indigenous and eight were imported from another country.

$\S \S$ Of 18 cases reported, six were indigenous and 12 were imported from another country.

ๆๆ Formerly Trichinosis. 
TABLE II. Provisional cases of selected notifiable diseases, United States, weeks ending June 25, 2005, and June 26, 2004 (25th Week)*

\begin{tabular}{|c|c|c|c|c|c|c|c|c|}
\hline \multirow[b]{2}{*}{ Reporting area } & \multicolumn{2}{|c|}{ AIDS } & \multicolumn{2}{|c|}{ Chlamydia $^{\dagger}$} & \multicolumn{2}{|c|}{ Coccidioidomycosis } & \multicolumn{2}{|c|}{ Cryptosporidiosis } \\
\hline & $\begin{array}{l}\text { Cum. } \\
2005^{\S}\end{array}$ & $\begin{array}{l}\text { Cum. } \\
2004\end{array}$ & $\begin{array}{l}\text { Cum. } \\
2005\end{array}$ & $\begin{array}{l}\text { Cum. } \\
2004\end{array}$ & $\begin{array}{l}\text { Cum. } \\
2005\end{array}$ & $\begin{array}{l}\text { Cum. } \\
2004\end{array}$ & $\begin{array}{l}\text { Cum. } \\
2005\end{array}$ & $\begin{array}{l}\text { Cum. } \\
2004\end{array}$ \\
\hline UNITED STATES & 16,504 & 19,333 & 423,967 & 438,780 & 1,978 & 2,576 & 872 & 1,146 \\
\hline $\begin{array}{l}\text { NEW ENGLAND } \\
\text { Maine } \\
\text { N.H. } \\
\text { Vt." } \\
\text { Mass. } \\
\text { R.I. } \\
\text { Conn. }\end{array}$ & $\begin{array}{r}673 \\
8 \\
10 \\
4 \\
331 \\
68 \\
252\end{array}$ & $\begin{array}{r}671 \\
5 \\
26 \\
13 \\
185 \\
70 \\
372\end{array}$ & $\begin{array}{r}14,961 \\
994 \\
882 \\
479 \\
6,783 \\
1,544 \\
4,279\end{array}$ & $\begin{array}{r}14,598 \\
927 \\
805 \\
560 \\
6,404 \\
1,661 \\
4,241\end{array}$ & $\begin{array}{l}\bar{N} \\
- \\
\overline{-} \\
\bar{N}\end{array}$ & $\begin{array}{l}\bar{N} \\
\overline{-} \\
\bar{N}\end{array}$ & $\begin{array}{r}49 \\
7 \\
7 \\
11 \\
17 \\
1 \\
6\end{array}$ & $\begin{array}{r}68 \\
13 \\
14 \\
7 \\
23 \\
2 \\
9\end{array}$ \\
\hline $\begin{array}{l}\text { MID. ATLANTIC } \\
\text { Upstate N.Y. } \\
\text { N.Y. City } \\
\text { N.J. } \\
\text { Pa. }\end{array}$ & $\begin{array}{r}3,059 \\
318 \\
1,725 \\
472 \\
544\end{array}$ & $\begin{array}{r}4,379 \\
587 \\
2,326 \\
741 \\
725\end{array}$ & $\begin{array}{r}50,986 \\
10,568 \\
17,386 \\
5,526 \\
17,506\end{array}$ & $\begin{array}{r}54,233 \\
10,654 \\
16,658 \\
8,650 \\
18,271\end{array}$ & $\begin{array}{l}\bar{N} \\
\bar{N} \\
N\end{array}$ & $\begin{array}{l}\bar{N} \\
\frac{N}{N}\end{array}$ & $\begin{array}{r}123 \\
32 \\
29 \\
8 \\
54\end{array}$ & $\begin{array}{r}184 \\
38 \\
56 \\
14 \\
76\end{array}$ \\
\hline $\begin{array}{l}\text { E.N. CENTRAL } \\
\text { Ohio } \\
\text { Ind. } \\
\text { III. } \\
\text { Mich. } \\
\text { Wis. }\end{array}$ & $\begin{array}{r}1,387 \\
209 \\
198 \\
664 \\
246 \\
70\end{array}$ & $\begin{array}{r}1,701 \\
229 \\
215 \\
846 \\
322 \\
89\end{array}$ & $\begin{array}{r}66,819 \\
18,689 \\
9,493 \\
19,605 \\
11,374 \\
7,658\end{array}$ & $\begin{array}{r}79,016 \\
20,345 \\
8,723 \\
22,395 \\
18,734 \\
8,819\end{array}$ & $\begin{array}{r}4 \\
\mathrm{~N} \\
\mathrm{~N} \\
4 \\
\mathrm{~N}\end{array}$ & $\begin{array}{r}5 \\
\mathrm{~N} \\
\mathrm{~N} \\
5 \\
\mathrm{~N}\end{array}$ & $\begin{array}{r}185 \\
66 \\
11 \\
12 \\
28 \\
68\end{array}$ & $\begin{array}{r}294 \\
65 \\
31 \\
46 \\
57 \\
95\end{array}$ \\
\hline $\begin{array}{l}\text { W.N. CENTRAL } \\
\text { Minn. } \\
\text { lowa } \\
\text { Mo. } \\
\text { N. Dak. } \\
\text { S. Dak. } \\
\text { Nebr.ף } \\
\text { Kans. }\end{array}$ & $\begin{array}{r}394 \\
104 \\
48 \\
163 \\
5 \\
9 \\
9 \\
18 \\
47\end{array}$ & $\begin{array}{r}384 \\
92 \\
26 \\
168 \\
13 \\
6 \\
21 \\
58\end{array}$ & $\begin{array}{r}25,104 \\
3,962 \\
2,951 \\
10,793 \\
501 \\
1,328 \\
2,393 \\
3,176\end{array}$ & $\begin{array}{r}26,698 \\
5,631 \\
3,213 \\
9,698 \\
918 \\
1,156 \\
2,500 \\
3,582\end{array}$ & $\begin{array}{l}3 \\
3 \\
N \\
N \\
- \\
N\end{array}$ & $\begin{array}{l}5 \\
N \\
N \\
3 \\
N \\
\\
2 \\
N\end{array}$ & $\begin{array}{r}133 \\
38 \\
22 \\
50 \\
11 \\
1 \\
11\end{array}$ & $\begin{array}{r}135 \\
52 \\
19 \\
21 \\
7 \\
16 \\
8 \\
12\end{array}$ \\
\hline $\begin{array}{l}\text { S. ATLANTIC } \\
\text { Del. } \\
\text { Md. } \\
\text { D.C. } \\
\text { Va. } \\
\text { W. Va. } \\
\text { N.C. } \\
\text { S.C. } \\
\text { Ga. } \\
\text { Fla. }\end{array}$ & $\begin{array}{r}5,315 \\
81 \\
637 \\
407 \\
273 \\
30 \\
399 \\
287 \\
896 \\
2,305\end{array}$ & $\begin{array}{r}5,729 \\
80 \\
686 \\
354 \\
283 \\
30 \\
334 \\
375 \\
779 \\
2,808\end{array}$ & $\begin{array}{r}82,385 \\
1,560 \\
8,684 \\
1,727 \\
9,713 \\
1,263 \\
16,477 \\
9,964 \\
12,485 \\
20,512\end{array}$ & $\begin{array}{r}82,021 \\
1,396 \\
8,978 \\
1,736 \\
10,292 \\
1,340 \\
13,686 \\
8,855 \\
15,426 \\
20,312\end{array}$ & $\begin{array}{l}\bar{N} \\
- \\
- \\
\mathrm{N} \\
\mathrm{N} \\
- \\
\mathrm{N}\end{array}$ & $\begin{array}{l}\bar{N} \\
- \\
\bar{N} \\
N \\
- \\
N\end{array}$ & $\begin{array}{r}174 \\
12 \\
2 \\
14 \\
4 \\
25 \\
7 \\
43 \\
67\end{array}$ & $\begin{array}{r}202 \\
10 \\
4 \\
23 \\
3 \\
37 \\
9 \\
61 \\
55\end{array}$ \\
\hline $\begin{array}{l}\text { E.S. CENTRAL } \\
\text { Ky. } \\
\text { Tenn." } \\
\text { Ala." } \\
\text { Miss. }\end{array}$ & $\begin{array}{l}896 \\
118 \\
369 \\
244 \\
165\end{array}$ & $\begin{array}{r}862 \\
68 \\
386 \\
227 \\
181\end{array}$ & $\begin{array}{r}29,704 \\
4,941 \\
10,677 \\
4,691 \\
9,395\end{array}$ & $\begin{array}{r}27,478 \\
2,649 \\
10,759 \\
6,592 \\
7,478\end{array}$ & $\begin{array}{l}\bar{N} \\
\mathrm{~N} \\
-\end{array}$ & $\begin{array}{l}3 \\
N \\
N \\
3\end{array}$ & $\begin{array}{r}23 \\
8 \\
4 \\
10 \\
1\end{array}$ & $\begin{array}{r}48 \\
16 \\
13 \\
11 \\
8\end{array}$ \\
\hline $\begin{array}{l}\text { W.S. CENTRAL } \\
\text { Ark. } \\
\text { La. } \\
\text { Okla. } \\
\text { Tex." }\end{array}$ & $\begin{array}{r}1,896 \\
71 \\
370 \\
113 \\
1,342\end{array}$ & $\begin{array}{r}2,356 \\
88 \\
444 \\
87 \\
1,737\end{array}$ & $\begin{array}{r}53,154 \\
4,197 \\
9,334 \\
5,224 \\
34,399\end{array}$ & $\begin{array}{r}55,887 \\
3,923 \\
12,370 \\
5,177 \\
34,417\end{array}$ & $\begin{array}{l}1 \\
1 \\
N \\
N\end{array}$ & $\begin{array}{l}2 \\
1 \\
1 \\
N \\
N\end{array}$ & $\begin{array}{r}25 \\
1 \\
3 \\
13 \\
8\end{array}$ & $\begin{array}{r}45 \\
8 \\
-11 \\
26\end{array}$ \\
\hline $\begin{array}{l}\text { MOUNTAIN } \\
\text { Mont. } \\
\text { Idaho" } \\
\text { Wyo. } \\
\text { Colo. } \\
\text { N. Mex. } \\
\text { Ariz. } \\
\text { Utah } \\
\text { Nev." }\end{array}$ & $\begin{array}{r}643 \\
4 \\
7 \\
1 \\
127 \\
60 \\
258 \\
33 \\
153\end{array}$ & $\begin{array}{r}713 \\
1 \\
11 \\
6 \\
134 \\
106 \\
278 \\
31 \\
146\end{array}$ & $\begin{array}{r}25,173 \\
998 \\
1,054 \\
518 \\
6,703 \\
1,945 \\
9,112 \\
1,864 \\
2,979\end{array}$ & $\begin{array}{r}24,335 \\
1,252 \\
1,407 \\
512 \\
6,309 \\
4,170 \\
6,572 \\
1,653 \\
2,460\end{array}$ & $\begin{array}{r}1,288 \\
N \\
N \\
2 \\
N \\
3 \\
1,250 \\
2 \\
31\end{array}$ & $\begin{array}{r}1,584 \\
\mathrm{~N} \\
\mathrm{~N} \\
\mathrm{~N} \\
10 \\
1,536 \\
7 \\
31\end{array}$ & $\begin{array}{r}54 \\
9 \\
4 \\
2 \\
18 \\
2 \\
5 \\
7 \\
7\end{array}$ & $\begin{array}{r}50 \\
10 \\
5 \\
2 \\
23 \\
2 \\
6 \\
1 \\
1\end{array}$ \\
\hline $\begin{array}{l}\text { PACIFIC } \\
\text { Wash. } \\
\text { Oreg. } \\
\text { Calif. } \\
\text { Alaska } \\
\text { Hawaii }\end{array}$ & $\begin{array}{r}2,241 \\
196 \\
117 \\
1,865 \\
10 \\
53\end{array}$ & $\begin{array}{r}2,538 \\
213 \\
131 \\
2,134 \\
14 \\
46\end{array}$ & $\begin{array}{r}75,681 \\
9,241 \\
4,096 \\
58,266 \\
1,853 \\
2,225\end{array}$ & $\begin{array}{r}74,514 \\
8,454 \\
3,877 \\
57,614 \\
1,851 \\
2,718\end{array}$ & $\begin{array}{r}682 \\
\mathrm{~N} \\
682 \\
- \\
-\end{array}$ & $\begin{array}{r}977 \\
\mathrm{~N} \\
\overline{977} \\
- \\
-\end{array}$ & $\begin{array}{r}106 \\
5 \\
19 \\
82 \\
-\end{array}$ & $\begin{array}{r}\frac{120}{17} \\
101 \\
\frac{2}{2}\end{array}$ \\
\hline $\begin{array}{l}\text { Guam } \\
\text { P.R. } \\
\text { V.I. } \\
\text { Amer. Samoa } \\
\text { C.N.M.I. }\end{array}$ & $\begin{array}{r}1 \\
335 \\
8 \\
\cup \\
2\end{array}$ & $\begin{array}{r}1 \\
208 \\
6 \\
\cup \\
\cup\end{array}$ & $\begin{array}{r}- \\
2,029 \\
32 \\
U \\
\end{array}$ & $\begin{array}{r}667 \\
1,803 \\
181 \\
\cup \\
U\end{array}$ & $\begin{array}{l}\bar{N} \\
\frac{U}{-}\end{array}$ & $\frac{\bar{N}}{U}$ & $\frac{\bar{N}}{\bar{U}}$ & $\frac{\bar{N}}{\bar{U}}$ \\
\hline
\end{tabular}

$\mathrm{N}$ : Not notifiable. U: Unavailable.

*

+ Chlamydia refers to genital infections caused by $C$. trachomatis.

$\S$ Updated monthly from reports to the Division of HIV/AIDS Prevention, National Center for HIV, STD, and TB Prevention. Last update May $29,2005$.

" Contains data reported through National Electronic Disease Surveillance System (NEDSS) 
TABLE II. (Continued) Provisional cases of selected notifiable diseases, United States, weeks ending June 25, 2005, and June 26, 2004 (25th Week)*

\begin{tabular}{|c|c|c|c|c|c|c|c|c|c|c|}
\hline \multirow[b]{3}{*}{ Reporting area } & \multicolumn{6}{|c|}{ Escherichia coli, Enterohemorrhagic (EHEC) } & \multirow{2}{*}{\multicolumn{2}{|c|}{ Giardiasis }} & \multirow{2}{*}{\multicolumn{2}{|c|}{ Gonorrhea }} \\
\hline & \multicolumn{2}{|c|}{ 0157:H7 } & \multicolumn{2}{|c|}{$\begin{array}{l}\text { Shiga toxin positive, } \\
\text { serogroup non- } 0157\end{array}$} & \multicolumn{2}{|c|}{$\begin{array}{c}\text { Shiga toxin positive, } \\
\text { not serogrouped }\end{array}$} & & & & \\
\hline & $\begin{array}{l}\text { Cum. } \\
2005 \\
\end{array}$ & $\begin{array}{l}\text { Cum. } \\
2004\end{array}$ & $\begin{array}{l}\text { Cum. } \\
2005\end{array}$ & $\begin{array}{l}\text { Cum. } \\
2004\end{array}$ & $\begin{array}{l}\text { Cum. } \\
2005\end{array}$ & $\begin{array}{l}\text { Cum. } \\
2004 \\
\end{array}$ & $\begin{array}{l}\text { Cum. } \\
2005 \\
\end{array}$ & $\begin{array}{l}\text { Cum. } \\
2004 \\
\end{array}$ & $\begin{array}{l}\text { Cum. } \\
2005 \\
\end{array}$ & $\begin{array}{l}\text { Cum. } \\
2004 \\
\end{array}$ \\
\hline UNITED STATES & 603 & 688 & 81 & 112 & 77 & 62 & 6,843 & 7,697 & 141,724 & 152,221 \\
\hline $\begin{array}{l}\text { NEW ENGLAND } \\
\text { Maine } \\
\text { N.H. } \\
\text { Vt. } \\
\text { Mass. } \\
\text { R.I. } \\
\text { Conn. }\end{array}$ & $\begin{array}{r}47 \\
7 \\
4 \\
5 \\
18 \\
2 \\
11\end{array}$ & $\begin{array}{r}49 \\
2 \\
9 \\
2 \\
25 \\
5 \\
6\end{array}$ & $\begin{array}{r}23 \\
5 \\
1 \\
-6 \\
11\end{array}$ & $\begin{array}{r}\frac{26}{5} \\
\frac{-}{8} \\
1 \\
12\end{array}$ & $\begin{array}{l}\frac{9}{-} \\
\frac{9}{-}\end{array}$ & $\begin{array}{l}7 \\
- \\
-7 \\
-\end{array}$ & $\begin{array}{r}623 \\
71 \\
28 \\
71 \\
262 \\
40 \\
151\end{array}$ & $\begin{array}{r}730 \\
64 \\
19 \\
59 \\
324 \\
54 \\
210\end{array}$ & $\begin{array}{r}2,879 \\
61 \\
76 \\
25 \\
1,300 \\
242 \\
1,175\end{array}$ & $\begin{array}{r}3,393 \\
122 \\
60 \\
43 \\
1,447 \\
427 \\
1,294\end{array}$ \\
\hline $\begin{array}{l}\text { MID. ATLANTIC } \\
\text { Upstate N.Y. } \\
\text { N.Y. City } \\
\text { N.J. } \\
\text { Pa. }\end{array}$ & $\begin{array}{r}70 \\
30 \\
2 \\
14 \\
24\end{array}$ & $\begin{array}{l}88 \\
36 \\
13 \\
17 \\
22\end{array}$ & $\begin{array}{r}4 \\
4 \\
- \\
- \\
-\end{array}$ & $\begin{array}{r}15 \\
6 \\
3 \\
6\end{array}$ & $\begin{array}{r}9 \\
3 \\
- \\
6\end{array}$ & $\begin{array}{r}12 \\
4 \\
-4 \\
4\end{array}$ & $\begin{array}{r}1,291 \\
449 \\
335 \\
171 \\
336\end{array}$ & $\begin{array}{r}1,702 \\
526 \\
523 \\
224 \\
429\end{array}$ & $\begin{array}{r}14,569 \\
3,005 \\
4,459 \\
2,066 \\
5,039\end{array}$ & $\begin{array}{r}17,249 \\
3,483 \\
5,343 \\
3,236 \\
5,187\end{array}$ \\
\hline $\begin{array}{l}\text { E.N. CENTRAL } \\
\text { Ohio } \\
\text { Ind. } \\
\text { III. } \\
\text { Mich. } \\
\text { Wis. }\end{array}$ & $\begin{array}{r}111 \\
39 \\
21 \\
14 \\
19 \\
18\end{array}$ & $\begin{array}{r}137 \\
30 \\
15 \\
31 \\
26 \\
35\end{array}$ & $\begin{array}{r}8 \\
1 \\
-1 \\
6\end{array}$ & $\begin{array}{r}20 \\
4 \\
1 \\
4 \\
11\end{array}$ & $\begin{array}{r}4 \\
2 \\
- \\
2 \\
-\end{array}$ & $\begin{array}{l}7 \\
6 \\
1 \\
- \\
-\end{array}$ & $\begin{array}{r}1,007 \\
287 \\
N \\
183 \\
290 \\
247\end{array}$ & $\begin{array}{r}1,159 \\
339 \\
N \\
368 \\
272 \\
180\end{array}$ & $\begin{array}{r}26,578 \\
8,635 \\
3,706 \\
7,868 \\
4,341 \\
2,028\end{array}$ & $\begin{array}{r}32,504 \\
10,330 \\
3,004 \\
9,466 \\
7,499 \\
2,205\end{array}$ \\
\hline $\begin{array}{l}\text { W.N. CENTRAL } \\
\text { Minn. } \\
\text { lowa } \\
\text { Mo. } \\
\text { N. Dak. } \\
\text { S. Dak. } \\
\text { Nebr. } \\
\text { Kans. }\end{array}$ & $\begin{array}{r}87 \\
12 \\
20 \\
28 \\
1 \\
3 \\
7 \\
16\end{array}$ & $\begin{array}{r}110 \\
28 \\
28 \\
19 \\
4 \\
5 \\
13 \\
13\end{array}$ & $\begin{array}{r}18 \\
6 \\
8 \\
1 \\
3 \\
-\end{array}$ & $\begin{array}{r}16 \\
7 \\
7 \\
- \\
2 \\
-\end{array}$ & $\begin{array}{r}10 \\
2 \\
- \\
- \\
- \\
3 \\
2\end{array}$ & $\begin{array}{r}14 \\
2 \\
4 \\
5 \\
-\end{array}$ & $\begin{array}{r}847 \\
423 \\
95 \\
176 \\
1 \\
36 \\
43 \\
73\end{array}$ & $\begin{array}{r}832 \\
276 \\
113 \\
240 \\
12 \\
28 \\
60 \\
103\end{array}$ & $\begin{array}{r}8,034 \\
1,125 \\
643 \\
4,392 \\
26 \\
182 \\
576 \\
1,090\end{array}$ & $\begin{array}{r}7,879 \\
1,404 \\
576 \\
3,977 \\
63 \\
124 \\
521 \\
1,214\end{array}$ \\
\hline $\begin{array}{l}\text { S. ATLANTIC } \\
\text { Del. } \\
\text { Md. } \\
\text { D.C. } \\
\text { Va. } \\
\text { W. Va. } \\
\text { N.C. } \\
\text { S.C. } \\
\text { Ga. } \\
\text { Fla. }\end{array}$ & $\begin{array}{r}\frac{85}{15} \\
\frac{1}{10} \\
1 \\
-1 \\
12 \\
46\end{array}$ & $\begin{array}{r}64 \\
1 \\
16 \\
1 \\
6 \\
1 \\
5 \\
14 \\
20\end{array}$ & $\begin{array}{l}12 \\
\mathrm{~N} \\
2 \\
6 \\
- \\
- \\
2 \\
2\end{array}$ & $\begin{array}{r}11 \\
\mathrm{~N} \\
2 \\
6 \\
- \\
- \\
1 \\
2\end{array}$ & $\begin{array}{l}36 \\
\mathrm{~N} \\
\frac{-}{8} \\
\frac{19}{-} \\
\frac{9}{9}\end{array}$ & $\begin{array}{r}10 \\
\mathrm{~N} \\
2 \\
- \\
- \\
- \\
- \\
-\end{array}$ & $\begin{array}{r}1,005 \\
16 \\
74 \\
21 \\
229 \\
13 \\
\mathrm{~N} \\
31 \\
227 \\
394\end{array}$ & $\begin{array}{r}1,194 \\
24 \\
44 \\
35 \\
170 \\
12 \\
\mathrm{~N} \\
41 \\
383 \\
485\end{array}$ & $\begin{array}{r}34,609 \\
382 \\
3,232 \\
924 \\
3,360 \\
353 \\
7,719 \\
4,228 \\
5,411 \\
9,000\end{array}$ & $\begin{array}{r}36,587 \\
442 \\
3,802 \\
1,190 \\
4,131 \\
394 \\
7,414 \\
4,316 \\
6,598 \\
8,300\end{array}$ \\
\hline $\begin{array}{l}\text { E.S. CENTRAL } \\
\text { Ky. } \\
\text { Tenn. } \\
\text { Ala. } \\
\text { Miss. }\end{array}$ & $\begin{array}{r}35 \\
8 \\
15 \\
11 \\
1\end{array}$ & $\begin{array}{r}46 \\
11 \\
15 \\
12 \\
8\end{array}$ & $\begin{array}{l}- \\
- \\
-\end{array}$ & $\begin{array}{r}3 \\
1 \\
- \\
2\end{array}$ & $\begin{array}{r}5 \\
4 \\
1 \\
- \\
-\end{array}$ & $\begin{array}{r}8 \\
5 \\
3 \\
- \\
-\end{array}$ & $\begin{array}{r}165 \\
N \\
82 \\
83 \\
-\end{array}$ & $\begin{array}{r}167 \\
\mathrm{~N} \\
82 \\
85 \\
-\end{array}$ & $\begin{array}{r}11,061 \\
1,557 \\
3,786 \\
2,819 \\
2,899\end{array}$ & $\begin{array}{r}11,892 \\
1,148 \\
3,852 \\
3,849 \\
3,043\end{array}$ \\
\hline $\begin{array}{l}\text { W.S. CENTRAL } \\
\text { Ark. } \\
\text { La. } \\
\text { Okla. } \\
\text { Tex. }\end{array}$ & $\begin{array}{r}19 \\
3 \\
3 \\
6 \\
7\end{array}$ & $\begin{array}{r}39 \\
8 \\
2 \\
7 \\
22\end{array}$ & $\begin{array}{l}\frac{3}{3} \\
- \\
-\end{array}$ & $\frac{1}{-}$ & $\frac{3}{\frac{2}{1}}$ & $\frac{4}{-}$ & $\begin{array}{r}106 \\
37 \\
17 \\
52 \\
\mathrm{~N}\end{array}$ & $\begin{array}{r}127 \\
53 \\
22 \\
52 \\
\mathrm{~N}\end{array}$ & $\begin{array}{r}21,010 \\
2,152 \\
5,033 \\
2,135 \\
11,690\end{array}$ & $\begin{array}{r}20,944 \\
1,974 \\
5,607 \\
2,174 \\
11,189\end{array}$ \\
\hline $\begin{array}{l}\text { MOUNTAIN } \\
\text { Mont. } \\
\text { Idaho } \\
\text { Wyo. } \\
\text { Colo. } \\
\text { N. Mex. } \\
\text { Ariz. } \\
\text { Utah } \\
\text { Nev. }\end{array}$ & $\begin{array}{r}55 \\
3 \\
7 \\
-15 \\
2 \\
12 \\
8 \\
8\end{array}$ & $\begin{array}{r}65 \\
3 \\
18 \\
1 \\
16 \\
6 \\
6 \\
7 \\
8\end{array}$ & $\begin{array}{l}11 \\
5 \\
2 \\
1 \\
3 \\
\mathrm{~N} \\
- \\
-\end{array}$ & $\begin{array}{r}19 \\
3 \\
1 \\
1 \\
3 \\
N \\
10 \\
1\end{array}$ & $\begin{array}{l}\frac{1}{-} \\
\frac{-}{-} \\
\frac{\mathrm{N}}{1}\end{array}$ & $\begin{array}{l}- \\
- \\
- \\
\bar{N} \\
-\end{array}$ & $\begin{array}{r}504 \\
18 \\
39 \\
11 \\
186 \\
16 \\
69 \\
132 \\
33\end{array}$ & $\begin{array}{r}568 \\
19 \\
77 \\
8 \\
189 \\
34 \\
80 \\
116 \\
45\end{array}$ & $\begin{array}{r}5,175 \\
54 \\
40 \\
30 \\
1,322 \\
349 \\
1,958 \\
294 \\
1,128\end{array}$ & $\begin{array}{r}5,231 \\
48 \\
38 \\
26 \\
1,507 \\
494 \\
1,774 \\
247 \\
1,097\end{array}$ \\
\hline $\begin{array}{l}\text { PACIFIC } \\
\text { Wash. } \\
\text { Oreg. } \\
\text { Calif. } \\
\text { Alaska } \\
\text { Hawaii }\end{array}$ & $\begin{array}{r}94 \\
21 \\
25 \\
39 \\
6 \\
3\end{array}$ & $\begin{array}{r}90 \\
28 \\
12 \\
46 \\
1 \\
3\end{array}$ & $\begin{array}{l}\frac{2}{2} \\
- \\
-\end{array}$ & $\begin{array}{l}\frac{1}{1} \\
- \\
-\end{array}$ & $\begin{array}{l}- \\
- \\
- \\
-\end{array}$ & $\begin{array}{l}- \\
- \\
- \\
-\end{array}$ & $\begin{array}{r}1,295 \\
116 \\
117 \\
994 \\
35 \\
33\end{array}$ & $\begin{array}{r}1,218 \\
120 \\
186 \\
841 \\
29 \\
42\end{array}$ & $\begin{array}{r}17,809 \\
1,681 \\
732 \\
14,736 \\
252 \\
408\end{array}$ & $\begin{array}{r}16,542 \\
1,249 \\
488 \\
13,842 \\
306 \\
657\end{array}$ \\
\hline $\begin{array}{l}\text { Guam } \\
\text { P.R. } \\
\text { V.I. } \\
\text { Amer. Samoa } \\
\text { C.N.M.I. }\end{array}$ & $\frac{N}{-}$ & $\frac{\mathrm{N}}{-}$ & $\begin{array}{l}- \\
\bar{U} \\
-\end{array}$ & $\frac{-}{\bar{U}}$ & $\begin{array}{l}- \\
\frac{-}{U}\end{array}$ & $\frac{-}{\bar{U}}$ & $\frac{\overline{25}}{\frac{U}{-}}$ & $\begin{array}{r}2 \\
84 \\
U\end{array}$ & $\begin{array}{r}1 \overline{-} \\
2 \\
U \\
-\end{array}$ & $\begin{array}{r}108 \\
138 \\
63 \\
\cup \\
U\end{array}$ \\
\hline
\end{tabular}

$\mathrm{N}$ : Not notifiable. U: Unavailable. $\quad$ - No reported cases. $\quad$ C.N.M.I.: Commonwealth of Northern Mariana Islands. * Incidence data for reporting years 2004 and 2005 are provisional and cumulative (year-to-date). 
TABLE II. (Continued) Provisional cases of selected notifiable diseases, United States, weeks ending June 25, 2005, and June 26, 2004 (25th Week)*

\begin{tabular}{|c|c|c|c|c|c|c|c|c|}
\hline \multirow[b]{4}{*}{ Reporting area } & \multicolumn{8}{|c|}{ Haemophilus influenzae, invasive } \\
\hline & \multirow{2}{*}{\multicolumn{2}{|c|}{$\begin{array}{c}\text { All ages } \\
\text { All serotypes }\end{array}$}} & \multicolumn{6}{|c|}{ Age $<5$ years } \\
\hline & & & \multicolumn{2}{|c|}{ Serotype b } & \multicolumn{2}{|c|}{ Non-serotype b } & \multicolumn{2}{|c|}{ Unknown serotype } \\
\hline & $\begin{array}{l}\text { Cum. } \\
2005\end{array}$ & $\begin{array}{l}\text { Cum. } \\
2004\end{array}$ & $\begin{array}{l}\text { Cum. } \\
2005\end{array}$ & $\begin{array}{l}\text { Cum. } \\
2004\end{array}$ & $\begin{array}{l}\text { Cum. } \\
2005\end{array}$ & $\begin{array}{l}\text { Cum. } \\
2004\end{array}$ & $\begin{array}{l}\text { Cum. } \\
2005\end{array}$ & $\begin{array}{l}\text { Cum. } \\
2004\end{array}$ \\
\hline UNITED STATES & 1,130 & 1,095 & 3 & 8 & 58 & 61 & 116 & 103 \\
\hline $\begin{array}{l}\text { NEW ENGLAND } \\
\text { Maine } \\
\text { N.H. } \\
\text { Vt. } \\
\text { Mass. } \\
\text { R.I. } \\
\text { Conn. }\end{array}$ & $\begin{array}{r}79 \\
4 \\
3 \\
6 \\
33 \\
7 \\
26\end{array}$ & $\begin{array}{r}108 \\
7 \\
13 \\
5 \\
54 \\
3 \\
26\end{array}$ & $\begin{array}{l}- \\
- \\
- \\
-\end{array}$ & $\begin{array}{l}1 \\
- \\
-1 \\
-\end{array}$ & $\begin{array}{l}6 \\
- \\
- \\
1 \\
2 \\
3\end{array}$ & $\begin{array}{l}\frac{7}{2} \\
\frac{2}{2} \\
\frac{3}{3}\end{array}$ & $\begin{array}{r}4 \\
1 \\
-2 \\
1 \\
-\end{array}$ & $\begin{array}{l}\frac{1}{-} \\
\frac{1}{-} \\
-\end{array}$ \\
\hline $\begin{array}{l}\text { MID. ATLANTIC } \\
\text { Upstate N.Y. } \\
\text { N.Y. City } \\
\text { N.J. } \\
\text { Pa. }\end{array}$ & $\begin{array}{r}220 \\
61 \\
38 \\
44 \\
77\end{array}$ & $\begin{array}{r}224 \\
77 \\
47 \\
40 \\
60\end{array}$ & $\begin{array}{l}- \\
- \\
-\end{array}$ & $\begin{array}{r}1 \\
1 \\
- \\
-\end{array}$ & $\begin{array}{l}- \\
- \\
-\end{array}$ & $\begin{array}{l}3 \\
3 \\
- \\
- \\
-\end{array}$ & $\begin{array}{r}28 \\
5 \\
9 \\
7 \\
7\end{array}$ & $\begin{array}{r}27 \\
4 \\
9 \\
2 \\
12\end{array}$ \\
\hline $\begin{array}{l}\text { E.N. CENTRAL } \\
\text { Ohio } \\
\text { Ind. } \\
\text { III. } \\
\text { Mich. } \\
\text { Wis. }\end{array}$ & $\begin{array}{r}147 \\
77 \\
39 \\
13 \\
11 \\
7\end{array}$ & $\begin{array}{r}203 \\
65 \\
30 \\
65 \\
12 \\
31\end{array}$ & $\begin{array}{l}\frac{1}{-} \\
\frac{1}{-}\end{array}$ & $\begin{array}{l}- \\
- \\
- \\
-\end{array}$ & $\begin{array}{l}\frac{1}{1} \\
- \\
-\end{array}$ & $\begin{array}{r}8 \\
2 \\
4 \\
-2 \\
-\end{array}$ & $\begin{array}{r}9 \\
7 \\
1 \\
1 \\
- \\
-\end{array}$ & $\begin{array}{r}28 \\
10 \\
1 \\
14 \\
3 \\
-\end{array}$ \\
\hline $\begin{array}{l}\text { W.N. CENTRAL } \\
\text { Minn. } \\
\text { lowa } \\
\text { Mo. } \\
\text { N. Dak. } \\
\text { S. Dak. } \\
\text { Nebr. } \\
\text { Kans. }\end{array}$ & $\begin{array}{r}62 \\
21 \\
\frac{-1}{30} \\
1 \\
-5 \\
5\end{array}$ & $\begin{array}{r}56 \\
24 \\
1 \\
20 \\
3 \\
2 \\
6\end{array}$ & $\begin{array}{l}- \\
- \\
- \\
- \\
-\end{array}$ & $\begin{array}{l}2 \\
1 \\
1 \\
- \\
- \\
- \\
-\end{array}$ & $\begin{array}{l}3 \\
3 \\
- \\
- \\
- \\
-\end{array}$ & $\begin{array}{l}3 \\
3 \\
- \\
- \\
- \\
-\end{array}$ & $\begin{array}{l}9 \\
- \\
7 \\
1 \\
-1 \\
-\end{array}$ & $\begin{array}{l}\frac{5}{-} \\
\frac{4}{-} \\
-\end{array}$ \\
\hline $\begin{array}{l}\text { S. ATLANTIC } \\
\text { Del. } \\
\text { Md. } \\
\text { D.C. } \\
\text { Va. } \\
\text { W. Va. } \\
\text { N.C. } \\
\text { S.C. } \\
\text { Ga. } \\
\text { Fla. }\end{array}$ & $\begin{array}{r}270 \\
39 \\
26 \\
14 \\
52 \\
10 \\
56 \\
73\end{array}$ & $\begin{array}{r}251 \\
43 \\
2 \\
21 \\
10 \\
35 \\
7 \\
72 \\
61\end{array}$ & $\begin{array}{l}1 \\
- \\
- \\
- \\
- \\
-\end{array}$ & $\begin{array}{l}- \\
- \\
- \\
- \\
- \\
-\end{array}$ & $\begin{array}{l}\frac{16}{4} \\
- \\
-1 \\
5 \\
- \\
6\end{array}$ & $\begin{array}{l}\frac{17}{4} \\
- \\
- \\
3 \\
- \\
-\end{array}$ & $\begin{array}{l}14 \\
- \\
- \\
- \\
2 \\
-1 \\
7 \\
4\end{array}$ & $\begin{array}{l}17 \\
- \\
1 \\
-1 \\
-1 \\
14 \\
-\end{array}$ \\
\hline $\begin{array}{l}\text { E.S. CENTRAL } \\
\text { Ky. } \\
\text { Tenn. } \\
\text { Ala. } \\
\text { Miss. }\end{array}$ & $\begin{array}{r}68 \\
6 \\
46 \\
16 \\
-\end{array}$ & $\begin{array}{r}42 \\
3 \\
28 \\
11 \\
-\end{array}$ & $\begin{array}{l}- \\
- \\
-\end{array}$ & $\begin{array}{l}- \\
- \\
-\end{array}$ & $\begin{array}{r}1 \\
1 \\
- \\
-\end{array}$ & $\begin{array}{l}- \\
- \\
-\end{array}$ & $\begin{array}{r}12 \\
1 \\
7 \\
4 \\
-\end{array}$ & $\begin{array}{l}7 \\
-5 \\
2 \\
-\end{array}$ \\
\hline $\begin{array}{l}\text { W.S. CENTRAL } \\
\text { Ark. } \\
\text { La. } \\
\text { Okla. } \\
\text { Tex. }\end{array}$ & $\begin{array}{r}70 \\
4 \\
27 \\
39 \\
-\end{array}$ & $\begin{array}{r}41 \\
1 \\
9 \\
30 \\
1\end{array}$ & $\begin{array}{l}1 \\
\frac{1}{-} \\
-\end{array}$ & $\frac{1}{-}$ & $\begin{array}{l}4 \\
2 \\
2 \\
-\end{array}$ & $\frac{5}{-}$ & $\begin{array}{r}7 \\
1 \\
6 \\
- \\
-\end{array}$ & $\begin{array}{l}\frac{1}{1} \\
- \\
-\end{array}$ \\
\hline $\begin{array}{l}\text { MOUNTAIN } \\
\text { Mont. } \\
\text { Idaho } \\
\text { Wyo. } \\
\text { Colo. } \\
\text { N. Mex. } \\
\text { Ariz. } \\
\text { Utah } \\
\text { Nev. }\end{array}$ & $\begin{array}{r}160 \\
3 \\
3 \\
29 \\
13 \\
88 \\
11 \\
13\end{array}$ & $\begin{array}{r}120 \\
\frac{5}{5} \\
29 \\
25 \\
43 \\
9 \\
9\end{array}$ & $\begin{array}{l}- \\
- \\
- \\
- \\
- \\
-\end{array}$ & $\begin{array}{l}3 \\
- \\
- \\
- \\
- \\
\\
1\end{array}$ & $\begin{array}{l}15 \\
- \\
- \\
- \\
4 \\
9 \\
2\end{array}$ & $\begin{array}{l}13 \\
- \\
- \\
- \\
4 \\
6 \\
1 \\
2\end{array}$ & $\begin{array}{r}27 \\
1 \\
1 \\
6 \\
1 \\
10 \\
6 \\
2\end{array}$ & $\begin{array}{l}12 \\
2 \\
3 \\
4 \\
1 \\
1 \\
1\end{array}$ \\
\hline $\begin{array}{l}\text { PACIFIC } \\
\text { Wash. } \\
\text { Oreg. } \\
\text { Calif. } \\
\text { Alaska } \\
\text { Hawaii }\end{array}$ & $\begin{array}{r}54 \\
20 \\
25 \\
4 \\
5\end{array}$ & $\begin{array}{r}50 \\
1 \\
25 \\
16 \\
4 \\
4\end{array}$ & $\begin{array}{l}- \\
- \\
- \\
-\end{array}$ & $\begin{array}{l}- \\
- \\
- \\
-\end{array}$ & $\begin{array}{l}\frac{12}{-} \\
\frac{12}{-} \\
-\end{array}$ & $\begin{array}{l}5 \\
\frac{5}{5} \\
-\end{array}$ & $\begin{array}{l}6 \\
4 \\
1 \\
1 \\
-\end{array}$ & $\begin{array}{r}5 \\
1 \\
2 \\
1 \\
1 \\
-\end{array}$ \\
\hline $\begin{array}{l}\text { Guam } \\
\text { P.R. } \\
\text { V.I. } \\
\text { Amer. Samoa } \\
\text { C.N.M.I. }\end{array}$ & $\frac{-}{\bar{U}}$ & $\frac{-}{\bar{U}}$ & $\frac{-}{\bar{U}}$ & $\frac{-}{U}$ & $\frac{-}{\bar{U}}$ & $\frac{-}{\bar{U}}$ & $\frac{-}{\bar{U}}$ & $\frac{-}{\bar{U}}$ \\
\hline
\end{tabular}

$\mathrm{N}$ : Not notifiable. U: Unavailable.

C.N.M.I.: Commonwealth of Northern Mariana Islands.

* Incidence data for reporting years 2004 and 2005 are provisional and cumulative (year-to-date). 
TABLE II. (Continued) Provisional cases of selected notifiable diseases, United States, weeks ending June 25, 2005, and June 26, 2004 (25th Week)*

\begin{tabular}{|c|c|c|c|c|c|c|}
\hline \multirow[b]{3}{*}{ Reporting area } & \multicolumn{6}{|c|}{ Hepatitis (viral, acute), by type } \\
\hline & \multicolumn{2}{|c|}{ A } & \multicolumn{2}{|c|}{ B } & \multicolumn{2}{|c|}{ C } \\
\hline & $\begin{array}{l}\text { Cum. } \\
2005\end{array}$ & $\begin{array}{l}\text { Cum. } \\
2004\end{array}$ & $\begin{array}{l}\text { Cum. } \\
2005\end{array}$ & $\begin{array}{l}\text { Cum. } \\
2004\end{array}$ & $\begin{array}{l}\text { Cum. } \\
2005\end{array}$ & $\begin{array}{l}\text { Cum. } \\
2004\end{array}$ \\
\hline UNITED STATES & 1,743 & 2,736 & 2,679 & 2,773 & 368 & 340 \\
\hline $\begin{array}{l}\text { NEW ENGLAND } \\
\text { Maine } \\
\text { N.H. } \\
\text { Vt. } \\
\text { Mass. } \\
\text { R.I. } \\
\text { Conn. }\end{array}$ & $\begin{array}{r}227 \\
-33 \\
2 \\
161 \\
5 \\
26\end{array}$ & $\begin{array}{r}400 \\
8 \\
11 \\
7 \\
333 \\
10 \\
31\end{array}$ & $\begin{array}{r}143 \\
8 \\
6 \\
2 \\
105 \\
1 \\
21\end{array}$ & $\begin{array}{r}178 \\
1 \\
22 \\
2 \\
87 \\
3 \\
63\end{array}$ & $\frac{6}{-}$ & $\begin{array}{l}6 \\
- \\
1 \\
5 \\
-\end{array}$ \\
\hline $\begin{array}{l}\text { MID. ATLANTIC } \\
\text { Upstate N.Y. } \\
\text { N.Y. City } \\
\text { N.J. } \\
\text { Pa. }\end{array}$ & $\begin{array}{r}275 \\
42 \\
137 \\
47 \\
49\end{array}$ & $\begin{array}{r}335 \\
39 \\
128 \\
75 \\
93\end{array}$ & $\begin{array}{r}569 \\
46 \\
47 \\
371 \\
105\end{array}$ & $\begin{array}{r}363 \\
35 \\
74 \\
98 \\
156\end{array}$ & $\begin{array}{l}50 \\
12 \\
- \\
38\end{array}$ & $\begin{array}{r}62 \\
2 \\
- \\
-60\end{array}$ \\
\hline $\begin{array}{l}\text { E.N. CENTRAL } \\
\text { Ohio } \\
\text { Ind. } \\
\text { III. } \\
\text { Mich. } \\
\text { Wis. }\end{array}$ & $\begin{array}{r}171 \\
27 \\
22 \\
37 \\
71 \\
14\end{array}$ & $\begin{array}{r}224 \\
26 \\
23 \\
72 \\
79 \\
24\end{array}$ & $\begin{array}{r}175 \\
68 \\
11 \\
15 \\
81 \\
-\end{array}$ & $\begin{array}{r}259 \\
64 \\
16 \\
33 \\
122 \\
24\end{array}$ & $\begin{array}{r}63 \\
1 \\
15 \\
47 \\
-\end{array}$ & $\begin{array}{r}40 \\
3 \\
3 \\
12 \\
22 \\
-\end{array}$ \\
\hline $\begin{array}{l}\text { W.N. CENTRAL } \\
\text { Minn. } \\
\text { lowa } \\
\text { Mo. } \\
\text { N. Dak. } \\
\text { S. Dak. } \\
\text { Nebr. } \\
\text { Kans. }\end{array}$ & $\begin{array}{r}57 \\
3 \\
17 \\
27 \\
- \\
3 \\
7\end{array}$ & $\begin{array}{r}77 \\
23 \\
24 \\
11 \\
1 \\
2 \\
9 \\
7\end{array}$ & $\begin{array}{r}185 \\
10 \\
67 \\
80 \\
- \\
14 \\
14\end{array}$ & $\begin{array}{r}171 \\
20 \\
11 \\
111 \\
2 \\
15 \\
12\end{array}$ & $\begin{array}{r}20 \\
\frac{3}{15} \\
\frac{1}{1} \\
\frac{1}{-}\end{array}$ & $\begin{array}{l}5 \\
4 \\
-1 \\
- \\
- \\
-\end{array}$ \\
\hline $\begin{array}{l}\text { S. ATLANTIC } \\
\text { Del. } \\
\text { Md. } \\
\text { D.C. } \\
\text { Va. } \\
\text { W. Va. } \\
\text { N.C. } \\
\text { S.C. } \\
\text { Ga. } \\
\text { Fla. }\end{array}$ & $\begin{array}{r}257 \\
1 \\
26 \\
2 \\
43 \\
3 \\
38 \\
8 \\
42 \\
94\end{array}$ & $\begin{array}{r}497 \\
5 \\
64 \\
4 \\
42 \\
1 \\
32 \\
28 \\
191 \\
130\end{array}$ & $\begin{array}{r}698 \\
34 \\
85 \\
4 \\
84 \\
19 \\
81 \\
41 \\
93 \\
257\end{array}$ & $\begin{array}{r}898 \\
25 \\
77 \\
13 \\
99 \\
2 \\
91 \\
66 \\
268 \\
257\end{array}$ & $\begin{array}{r}127 \\
59 \\
17 \\
8 \\
5 \\
5 \\
9 \\
1 \\
4 \\
24\end{array}$ & $\begin{array}{r}87 \\
4 \\
2 \\
1 \\
8 \\
14 \\
6 \\
8 \\
7 \\
37\end{array}$ \\
\hline $\begin{array}{l}\text { E.S. CENTRAL } \\
\text { Ky. } \\
\text { Tenn. } \\
\text { Ala. } \\
\text { Miss. }\end{array}$ & $\begin{array}{r}116 \\
6 \\
83 \\
14 \\
13\end{array}$ & $\begin{array}{r}79 \\
11 \\
54 \\
6 \\
8\end{array}$ & $\begin{array}{r}181 \\
36 \\
68 \\
40 \\
37\end{array}$ & $\begin{array}{r}229 \\
25 \\
109 \\
38 \\
57\end{array}$ & $\begin{array}{r}43 \\
3 \\
9 \\
8 \\
23\end{array}$ & $\begin{array}{r}36 \\
16 \\
9 \\
2 \\
9\end{array}$ \\
\hline $\begin{array}{l}\text { W.S. CENTRAL } \\
\text { Ark. } \\
\text { La. } \\
\text { Okla. } \\
\text { Tex. }\end{array}$ & $\begin{array}{r}106 \\
3 \\
36 \\
3 \\
64\end{array}$ & $\begin{array}{r}373 \\
48 \\
19 \\
17 \\
289\end{array}$ & $\begin{array}{r}180 \\
20 \\
27 \\
20 \\
113\end{array}$ & $\begin{array}{r}132 \\
57 \\
27 \\
34 \\
14\end{array}$ & $\frac{\frac{18}{8}}{\frac{8}{10}}$ & $\begin{array}{r}54 \\
1 \\
3 \\
2 \\
48\end{array}$ \\
\hline $\begin{array}{l}\text { MOUNTAIN } \\
\text { Mont. } \\
\text { Idaho } \\
\text { Wyo. } \\
\text { Colo. } \\
\text { N. Mex. } \\
\text { Ariz. } \\
\text { Utah } \\
\text { Nev. }\end{array}$ & $\begin{array}{r}168 \\
7 \\
15 \\
19 \\
19 \\
8 \\
100 \\
13 \\
6\end{array}$ & $\begin{array}{r}211 \\
4 \\
10 \\
2 \\
20 \\
10 \\
137 \\
22 \\
6\end{array}$ & $\begin{array}{r}259 \\
3 \\
5 \\
1 \\
22 \\
7 \\
177 \\
26 \\
18\end{array}$ & $\begin{array}{r}209 \\
1 \\
6 \\
6 \\
23 \\
10 \\
105 \\
18 \\
40\end{array}$ & $\begin{array}{l}17 \\
- \\
- \\
- \\
- \\
6 \\
3\end{array}$ & $\begin{array}{r}19 \\
2 \\
1 \\
4 \\
U \\
2 \\
2 \\
8\end{array}$ \\
\hline $\begin{array}{l}\text { PACIFIC } \\
\text { Wash. } \\
\text { Oreg. } \\
\text { Calif. } \\
\text { Alaska } \\
\text { Hawaii }\end{array}$ & $\begin{array}{r}366 \\
21 \\
26 \\
306 \\
3 \\
10\end{array}$ & $\begin{array}{r}540 \\
31 \\
39 \\
454 \\
3 \\
13\end{array}$ & $\begin{array}{r}289 \\
33 \\
46 \\
202 \\
6 \\
2\end{array}$ & $\begin{array}{r}334 \\
26 \\
55 \\
241 \\
8 \\
4\end{array}$ & $\begin{array}{r}24 \\
4 \\
9 \\
11 \\
- \\
-\end{array}$ & $\begin{array}{r}31 \\
9 \\
9 \\
12 \\
1\end{array}$ \\
\hline $\begin{array}{l}\text { Guam } \\
\text { P.R. } \\
\text { V.I. } \\
\text { Amer. Samoa } \\
\text { C.N.M.I. }\end{array}$ & $\frac{-}{\frac{8}{U}}$ & $\frac{1}{21}$ & $\frac{\overline{6}}{\bar{U}}$ & $\begin{array}{l}10 \\
37 \\
U \\
U\end{array}$ & $\frac{-}{\bar{U}}$ & $\frac{8}{-}$ \\
\hline
\end{tabular}

$\mathrm{N}$ : Not notifiable.

- No reported cases.

C.N.M.I: Commonwealth of Northern Mariana Islands.

* Incidence data for reporting years 2004 and 2005 are provisional and cumulative (year-to-date). 
TABLE II. (Continued) Provisional cases of selected notifiable diseases, United States, weeks ending June 25, 2005, and June 26, 2004 (25th Week)*

\begin{tabular}{|c|c|c|c|c|c|c|c|c|}
\hline \multirow[b]{2}{*}{ Reporting area } & \multicolumn{2}{|c|}{ Legionellosis } & \multicolumn{2}{|c|}{ Listeriosis } & \multicolumn{2}{|c|}{ Lyme disease } & \multicolumn{2}{|c|}{ Malaria } \\
\hline & $\begin{array}{l}\text { Cum. } \\
2005\end{array}$ & $\begin{array}{l}\text { Cum. } \\
2004\end{array}$ & $\begin{array}{l}\text { Cum. } \\
2005\end{array}$ & $\begin{array}{l}\text { Cum. } \\
2004\end{array}$ & $\begin{array}{l}\text { Cum. } \\
2005\end{array}$ & $\begin{array}{l}\text { Cum. } \\
2004\end{array}$ & $\begin{array}{l}\text { Cum. } \\
2005\end{array}$ & $\begin{array}{l}\text { Cum. } \\
2004\end{array}$ \\
\hline UNITED STATES & 538 & 672 & 224 & 261 & 3,218 & 5,585 & 474 & 598 \\
\hline $\begin{array}{l}\text { NEW ENGLAND } \\
\text { Maine } \\
\text { N.H. } \\
\text { Vt. } \\
\text { Mass. } \\
\text { R.I. } \\
\text { Conn. }\end{array}$ & $\begin{array}{r}33 \\
1 \\
4 \\
19 \\
3 \\
6\end{array}$ & $\begin{array}{r}19 \\
- \\
1 \\
11 \\
2 \\
5\end{array}$ & $\begin{array}{l}8 \\
1 \\
4 \\
1 \\
2\end{array}$ & $\begin{array}{r}11 \\
2 \\
1 \\
3 \\
1 \\
4\end{array}$ & $\begin{array}{r}201 \\
15 \\
23 \\
5 \\
110 \\
3 \\
45\end{array}$ & $\begin{array}{r}897 \\
29 \\
40 \\
13 \\
559 \\
60 \\
196\end{array}$ & $\begin{array}{r}24 \\
3 \\
3 \\
16 \\
2 \\
\end{array}$ & $\begin{array}{r}53 \\
4 \\
-3 \\
31 \\
2 \\
13\end{array}$ \\
\hline $\begin{array}{l}\text { MID. ATLANTIC } \\
\text { Upstate N.Y. } \\
\text { N.Y. City } \\
\text { N.J. } \\
\text { Pa. }\end{array}$ & $\begin{array}{r}154 \\
38 \\
18 \\
34 \\
64\end{array}$ & $\begin{array}{r}153 \\
30 \\
18 \\
22 \\
83\end{array}$ & $\begin{array}{r}47 \\
13 \\
7 \\
9 \\
18\end{array}$ & $\begin{array}{r}58 \\
17 \\
9 \\
16 \\
16\end{array}$ & $\begin{array}{r}2,236 \\
502 \\
- \\
945 \\
789\end{array}$ & $\begin{array}{r}3,700 \\
1,103 \\
120 \\
1,092 \\
1,385\end{array}$ & $\begin{array}{r}129 \\
23 \\
58 \\
31 \\
17\end{array}$ & $\begin{array}{r}152 \\
18 \\
74 \\
34 \\
26\end{array}$ \\
\hline $\begin{array}{l}\text { E.N. CENTRAL } \\
\text { Ohio } \\
\text { Ind. } \\
\text { III. } \\
\text { Mich. } \\
\text { Wis. }\end{array}$ & $\begin{array}{r}104 \\
48 \\
6 \\
12 \\
30 \\
8\end{array}$ & $\begin{array}{r}155 \\
72 \\
13 \\
23 \\
40 \\
7\end{array}$ & $\begin{array}{r}23 \\
10 \\
1 \\
-7 \\
5\end{array}$ & $\begin{array}{r}45 \\
15 \\
8 \\
8 \\
12 \\
2\end{array}$ & $\begin{array}{r}45 \\
30 \\
4 \\
-3 \\
8\end{array}$ & $\begin{array}{r}383 \\
21 \\
4 \\
42 \\
4 \\
312\end{array}$ & $\begin{array}{r}33 \\
10 \\
9 \\
11 \\
3\end{array}$ & $\begin{array}{r}52 \\
12 \\
6 \\
17 \\
10 \\
7\end{array}$ \\
\hline $\begin{array}{l}\text { W.N. CENTRAL } \\
\text { Minn. } \\
\text { lowa } \\
\text { Mo. } \\
\text { N. Dak. } \\
\text { S. Dak. } \\
\text { Nebr. } \\
\text { Kans. }\end{array}$ & $\begin{array}{r}15 \\
1 \\
2 \\
9 \\
1 \\
- \\
2\end{array}$ & $\begin{array}{r}16 \\
1 \\
3 \\
8 \\
1 \\
1 \\
1 \\
1\end{array}$ & $\begin{array}{r}11 \\
2 \\
4 \\
2 \\
2 \\
- \\
1\end{array}$ & $\begin{array}{l}5 \\
1 \\
1 \\
2 \\
- \\
1 \\
-\end{array}$ & $\begin{array}{r}116 \\
90 \\
13 \\
11 \\
- \\
- \\
2\end{array}$ & $\begin{array}{l}63 \\
25 \\
13 \\
19 \\
- \\
4 \\
2\end{array}$ & $\begin{array}{r}24 \\
11 \\
2 \\
10 \\
- \\
- \\
1\end{array}$ & $\begin{array}{r}37 \\
16 \\
1 \\
10 \\
2 \\
1 \\
2 \\
5\end{array}$ \\
\hline $\begin{array}{l}\text { S. ATLANTIC } \\
\text { Del. } \\
\text { Md. } \\
\text { D.C. } \\
\text { Va. } \\
\text { W. Va. } \\
\text { N.C. } \\
\text { S.C. } \\
\text { Ga. } \\
\text { Fla. }\end{array}$ & $\begin{array}{r}127 \\
8 \\
34 \\
2 \\
12 \\
4 \\
13 \\
2 \\
8 \\
44\end{array}$ & $\begin{array}{r}147 \\
3 \\
25 \\
7 \\
9 \\
2 \\
15 \\
4 \\
23 \\
59\end{array}$ & $\begin{array}{r}53 \\
\mathrm{~N} \\
8 \\
5 \\
1 \\
10 \\
1 \\
10 \\
18\end{array}$ & $\begin{array}{r}36 \\
\mathrm{~N} \\
5 \\
- \\
4 \\
1 \\
8 \\
1 \\
8 \\
9\end{array}$ & $\begin{array}{r}529 \\
174 \\
252 \\
3 \\
40 \\
4 \\
22 \\
7 \\
-27\end{array}$ & $\begin{array}{r}470 \\
58 \\
308 \\
2 \\
24 \\
2 \\
45 \\
5 \\
8 \\
18\end{array}$ & $\begin{array}{r}97 \\
34 \\
2 \\
11 \\
1 \\
1 \\
14 \\
3 \\
14 \\
18\end{array}$ & $\begin{array}{r}140 \\
3 \\
29 \\
7 \\
11 \\
9 \\
7 \\
28 \\
46\end{array}$ \\
\hline $\begin{array}{l}\text { E.S. CENTRAL } \\
\text { Ky. } \\
\text { Tenn. } \\
\text { Ala. } \\
\text { Miss. }\end{array}$ & $\begin{array}{r}21 \\
7 \\
7 \\
7 \\
-\end{array}$ & $\begin{array}{r}32 \\
8 \\
12 \\
11 \\
1\end{array}$ & $\begin{array}{r}11 \\
1 \\
5 \\
4 \\
1\end{array}$ & $\begin{array}{r}15 \\
4 \\
7 \\
2 \\
2\end{array}$ & $\begin{array}{r}15 \\
1 \\
14 \\
- \\
\end{array}$ & $\begin{array}{r}22 \\
10 \\
9 \\
3 \\
-\end{array}$ & $\begin{array}{r}12 \\
3 \\
6 \\
3 \\
\end{array}$ & $\begin{array}{r}18 \\
1 \\
3 \\
11 \\
3\end{array}$ \\
\hline $\begin{array}{l}\text { W.S. CENTRAL } \\
\text { Ark. } \\
\text { La. } \\
\text { Okla. } \\
\text { Tex. }\end{array}$ & $\begin{array}{r}10 \\
1 \\
4 \\
2 \\
3\end{array}$ & $\begin{array}{r}87 \\
5 \\
2 \\
80\end{array}$ & $\frac{10}{\frac{4}{6}}$ & $\begin{array}{r}23 \\
2 \\
2 \\
19\end{array}$ & $\begin{array}{r}32 \\
2 \\
4 \\
26\end{array}$ & $\begin{array}{r}14 \\
2 \\
1 \\
11\end{array}$ & $\begin{array}{r}33 \\
2 \\
2 \\
2 \\
27\end{array}$ & $\begin{array}{r}60 \\
6 \\
3 \\
2 \\
49\end{array}$ \\
\hline $\begin{array}{l}\text { MOUNTAIN } \\
\text { Mont. } \\
\text { Idaho } \\
\text { Wyo. } \\
\text { Colo. } \\
\text { N. Mex. } \\
\text { Ariz. } \\
\text { Utah } \\
\text { Nev. }\end{array}$ & $\begin{array}{r}44 \\
3 \\
1 \\
3 \\
11 \\
1 \\
1 \\
13 \\
5 \\
7\end{array}$ & $\begin{array}{r}35 \\
1 \\
4 \\
4 \\
6 \\
1 \\
5 \\
11 \\
3\end{array}$ & $\begin{array}{l}2 \\
- \\
-1 \\
- \\
- \\
-\end{array}$ & $\begin{array}{l}\frac{11}{1} \\
\frac{1}{3} \\
- \\
-1 \\
6\end{array}$ & $\begin{array}{l}3 \\
\frac{1}{-} \\
- \\
- \\
- \\
-\end{array}$ & $\begin{array}{l}5 \\
2 \\
2 \\
- \\
-1 \\
-\end{array}$ & $\begin{array}{r}25 \\
- \\
1 \\
14 \\
5 \\
4 \\
1\end{array}$ & $\begin{array}{l}20 \\
1 \\
7 \\
1 \\
5 \\
3 \\
3\end{array}$ \\
\hline $\begin{array}{l}\text { PACIFIC } \\
\text { Wash. } \\
\text { Oreg. } \\
\text { Calif. } \\
\text { Alaska } \\
\text { Hawaii }\end{array}$ & $\begin{array}{l}30 \\
\mathrm{~N} \\
30 \\
-\end{array}$ & $\begin{array}{r}28 \\
4 \\
\mathrm{~N} \\
24 \\
- \\
-\end{array}$ & $\begin{array}{r}59 \\
4 \\
4 \\
51 \\
- \\
-\end{array}$ & $\begin{array}{r}57 \\
6 \\
4 \\
47 \\
- \\
\end{array}$ & $\begin{array}{r}41 \\
5 \\
35 \\
1 \\
\mathrm{~N}\end{array}$ & $\begin{array}{r}31 \\
2 \\
14 \\
15 \\
\mathrm{~N}\end{array}$ & $\begin{array}{r}97 \\
7 \\
3 \\
80 \\
3 \\
4\end{array}$ & $\begin{array}{r}66 \\
3 \\
10 \\
51 \\
2\end{array}$ \\
\hline $\begin{array}{l}\text { Guam } \\
\text { P.R. } \\
\text { V.I. } \\
\text { Amer. Samoa } \\
\text { C.N.M.I. }\end{array}$ & $\begin{array}{l}- \\
\bar{U} \\
-\end{array}$ & $\begin{array}{l}- \\
\bar{U} \\
U\end{array}$ & $\begin{array}{l}- \\
- \\
-\end{array}$ & $\frac{-}{-}$ & $\frac{\bar{N}}{U}$ & $\frac{\bar{N}}{U}$ & $\begin{array}{c}- \\
- \\
U\end{array}$ & $\frac{-}{-}$ \\
\hline
\end{tabular}

$\mathrm{N}$ : Not notifiable. U: Unavailable. 
TABLE II. (Continued) Provisional cases of selected notifiable diseases, United States, weeks ending June 25, 2005, and June 26, 2004 (25th Week)*

\begin{tabular}{|c|c|c|c|c|c|c|c|c|c|c|}
\hline \multirow[b]{3}{*}{ Reporting area } & \multicolumn{10}{|c|}{ Meningococcal disease } \\
\hline & \multicolumn{2}{|c|}{ All serogroups } & \multicolumn{2}{|c|}{$\begin{array}{c}\text { Serogroup } \\
A, C, Y, \text { and } W-135\end{array}$} & \multicolumn{2}{|c|}{ Serogroup B } & \multicolumn{2}{|c|}{ Other serogroup } & \multicolumn{2}{|c|}{ Serogroup unknown } \\
\hline & $\begin{array}{l}\text { Cum. } \\
2005 \\
\end{array}$ & $\begin{array}{l}\text { Cum. } \\
2004 \\
\end{array}$ & $\begin{array}{l}\text { Cum. } \\
2005 \\
\end{array}$ & $\begin{array}{l}\text { Cum. } \\
2004 \\
\end{array}$ & $\begin{array}{l}\text { Cum. } \\
2005 \\
\end{array}$ & $\begin{array}{l}\text { Cum. } \\
2004\end{array}$ & $\begin{array}{l}\text { Cum. } \\
2005 \\
\end{array}$ & $\begin{array}{l}\text { Cum. } \\
2004\end{array}$ & $\begin{array}{l}\text { Cum. } \\
2005 \\
\end{array}$ & $\begin{array}{l}\text { Cum. } \\
2004 \\
\end{array}$ \\
\hline UNITED STATES & 674 & 715 & 51 & 54 & 33 & 29 & - & 1 & 590 & 631 \\
\hline $\begin{array}{l}\text { NEW ENGLAND } \\
\text { Maine } \\
\text { N.H. } \\
\text { Vt. } \\
\text { Mass. } \\
\text { R.I. } \\
\text { Conn. }\end{array}$ & $\begin{array}{r}48 \\
2 \\
6 \\
4 \\
24 \\
2 \\
10\end{array}$ & $\begin{array}{r}38 \\
8 \\
3 \\
1 \\
22 \\
1 \\
3\end{array}$ & $\begin{array}{l}\frac{1}{-} \\
- \\
- \\
1\end{array}$ & $\begin{array}{l}\frac{4}{-} \\
- \\
- \\
-\end{array}$ & $\begin{array}{l}\overline{-} \\
\overline{-} \\
\overline{-} \\
-\end{array}$ & $\begin{array}{l}5 \\
1 \\
- \\
-4 \\
-\end{array}$ & $\begin{array}{l}\overline{-} \\
\overline{-} \\
\overline{-} \\
\overline{-}\end{array}$ & $\begin{array}{l}1 \\
- \\
\overline{-} \\
\overline{1}\end{array}$ & $\begin{array}{r}47 \\
2 \\
6 \\
4 \\
24 \\
2 \\
9\end{array}$ & $\begin{array}{r}28 \\
7 \\
3 \\
1 \\
14 \\
1 \\
2\end{array}$ \\
\hline $\begin{array}{l}\text { MID. ATLANTIC } \\
\text { Upstate N.Y. } \\
\text { N.Y. City } \\
\text { N.J. } \\
\text { Pa. }\end{array}$ & $\begin{array}{l}90 \\
22 \\
12 \\
26 \\
30\end{array}$ & $\begin{array}{r}106 \\
30 \\
19 \\
20 \\
37\end{array}$ & $\begin{array}{l}26 \\
-3 \\
- \\
23\end{array}$ & $\begin{array}{r}31 \\
5 \\
- \\
-26\end{array}$ & $\begin{array}{l}4 \\
3 \\
- \\
-1\end{array}$ & $\begin{array}{l}5 \\
3 \\
- \\
2\end{array}$ & $\begin{array}{l}\overline{-} \\
\overline{-} \\
-\end{array}$ & $\begin{array}{l}\overline{-} \\
\overline{-} \\
-\end{array}$ & $\begin{array}{r}60 \\
16 \\
12 \\
26 \\
6\end{array}$ & $\begin{array}{r}70 \\
22 \\
19 \\
20 \\
9\end{array}$ \\
\hline $\begin{array}{l}\text { E.N. CENTRAL } \\
\text { Ohio } \\
\text { Ind. } \\
\text { III. } \\
\text { Mich. } \\
\text { Wis. }\end{array}$ & $\begin{array}{r}60 \\
28 \\
9 \\
3 \\
15 \\
5\end{array}$ & $\begin{array}{r}75 \\
41 \\
11 \\
1 \\
10 \\
12\end{array}$ & $\begin{array}{l}\frac{15}{-} \\
\frac{15}{-}\end{array}$ & $\begin{array}{l}13 \\
3 \\
\frac{3}{10} \\
-\end{array}$ & $\begin{array}{l}5 \\
5 \\
- \\
- \\
-\end{array}$ & $\begin{array}{l}5 \\
4 \\
1 \\
- \\
- \\
-\end{array}$ & $\begin{array}{l}= \\
\overline{-} \\
\overline{-} \\
-\end{array}$ & $\begin{array}{l}= \\
\overline{-} \\
\overline{-} \\
-\end{array}$ & $\begin{array}{r}40 \\
23 \\
9 \\
3 \\
5\end{array}$ & $\begin{array}{r}57 \\
34 \\
10 \\
1 \\
12\end{array}$ \\
\hline $\begin{array}{l}\text { W.N. CENTRAL } \\
\text { Minn. } \\
\text { lowa } \\
\text { Mo. } \\
\text { N. Dak. } \\
\text { S. Dak. } \\
\text { Nebr. } \\
\text { Kans. }\end{array}$ & $\begin{array}{r}44 \\
6 \\
12 \\
15 \\
2 \\
3 \\
6\end{array}$ & $\begin{array}{r}46 \\
13 \\
10 \\
14 \\
1 \\
1 \\
2 \\
5\end{array}$ & $\begin{array}{l}2 \\
1 \\
-1 \\
- \\
= \\
-\end{array}$ & $\begin{array}{l}= \\
\overline{-} \\
= \\
\overline{-} \\
-\end{array}$ & $\begin{array}{l}\frac{1}{1} \\
- \\
- \\
-\end{array}$ & $\begin{array}{l}\frac{3}{2} \\
1 \\
- \\
- \\
-\end{array}$ & $\begin{array}{l}= \\
\overline{-} \\
= \\
= \\
=\end{array}$ & $\begin{array}{l}= \\
\overline{-} \\
= \\
= \\
=\end{array}$ & $\begin{array}{r}41 \\
5 \\
11 \\
14 \\
-2 \\
2 \\
3 \\
6\end{array}$ & $\begin{array}{r}43 \\
13 \\
8 \\
13 \\
1 \\
1 \\
2 \\
5\end{array}$ \\
\hline $\begin{array}{l}\text { S. ATLANTIC } \\
\text { Del. } \\
\text { Md. } \\
\text { D.C. } \\
\text { Va. } \\
\text { W. Va. } \\
\text { N.C. } \\
\text { S.C. } \\
\text { Ga. } \\
\text { Fla. }\end{array}$ & $\begin{array}{r}126 \\
2 \\
12 \\
16 \\
5 \\
17 \\
11 \\
12 \\
51\end{array}$ & $\begin{array}{r}141 \\
2 \\
7 \\
5 \\
9 \\
4 \\
21 \\
13 \\
9 \\
71\end{array}$ & $\begin{array}{l}\frac{3}{1} \\
- \\
-1 \\
1 \\
- \\
-\end{array}$ & $\begin{array}{l}\frac{2}{-} \\
2 \\
= \\
= \\
=\end{array}$ & $\begin{array}{l}\frac{5}{2} \\
\frac{-}{-} \\
-3 \\
=\end{array}$ & $\begin{array}{l}2 \\
= \\
= \\
= \\
\frac{2}{-} \\
-\end{array}$ & $\begin{array}{l}= \\
= \\
= \\
= \\
= \\
=\end{array}$ & $\begin{array}{l}= \\
\overline{-} \\
= \\
= \\
= \\
=\end{array}$ & $\begin{array}{r}118 \\
2 \\
9 \\
16 \\
4 \\
13 \\
11 \\
12 \\
51\end{array}$ & $\begin{array}{r}137 \\
2 \\
7 \\
3 \\
9 \\
4 \\
19 \\
13 \\
9 \\
71\end{array}$ \\
\hline $\begin{array}{l}\text { E.S. CENTRAL } \\
\text { Ky. } \\
\text { Tenn. } \\
\text { Ala. } \\
\text { Miss. }\end{array}$ & $\begin{array}{r}34 \\
11 \\
15 \\
4 \\
4\end{array}$ & $\begin{array}{r}34 \\
4 \\
11 \\
9 \\
10\end{array}$ & $\begin{array}{l}- \\
\overline{-} \\
-\end{array}$ & $\begin{array}{l}- \\
\overline{-} \\
-\end{array}$ & $\begin{array}{l}3 \\
3 \\
- \\
-\end{array}$ & $\begin{array}{l}- \\
\overline{-} \\
\overline{-}\end{array}$ & $\begin{array}{l}- \\
\bar{z} \\
-\end{array}$ & $\begin{array}{l}- \\
\overline{-} \\
\overline{-}\end{array}$ & $\begin{array}{r}31 \\
8 \\
15 \\
4 \\
4\end{array}$ & $\begin{array}{r}34 \\
4 \\
11 \\
9 \\
10\end{array}$ \\
\hline $\begin{array}{l}\text { W.S. CENTRAL } \\
\text { Ark. } \\
\text { La. } \\
\text { Okla. } \\
\text { Tex. }\end{array}$ & $\begin{array}{r}53 \\
9 \\
22 \\
12 \\
10\end{array}$ & $\begin{array}{r}41 \\
10 \\
24 \\
4 \\
3\end{array}$ & $\frac{1}{-}$ & $\begin{array}{l}\frac{1}{1} \\
\frac{1}{-}\end{array}$ & $\begin{array}{r}\frac{5}{2} \\
3 \\
-\end{array}$ & $\frac{1}{-}$ & $\begin{array}{l}\overline{-} \\
\overline{-} \\
-\end{array}$ & $\begin{array}{l}- \\
\overline{-} \\
\overline{-}\end{array}$ & $\begin{array}{r}47 \\
9 \\
20 \\
8 \\
10\end{array}$ & $\begin{array}{r}39 \\
10 \\
23 \\
3 \\
3\end{array}$ \\
\hline $\begin{array}{l}\text { MOUNTAIN } \\
\text { Mont. } \\
\text { Idaho } \\
\text { Wyo. } \\
\text { Colo. } \\
\text { N. Mex. } \\
\text { Ariz. } \\
\text { Utah } \\
\text { Nev. }\end{array}$ & $\begin{array}{r}\frac{59}{1} \\
\overline{13} \\
1 \\
32 \\
7 \\
5\end{array}$ & $\begin{array}{r}40 \\
3 \\
4 \\
3 \\
11 \\
6 \\
6 \\
2 \\
5\end{array}$ & $\begin{array}{l}\frac{2}{-} \\
\overline{-} \\
\frac{2}{-} \\
= \\
-\end{array}$ & $\begin{array}{l}\frac{1}{-} \\
\overline{-} \\
\overline{1} \\
- \\
-\end{array}$ & $\begin{array}{l}5 \\
\overline{-} \\
- \\
- \\
\overline{2} \\
2 \\
1\end{array}$ & $\begin{array}{c}\frac{4}{E} \\
- \\
\overline{-} \\
\frac{3}{-} \\
\overline{1}\end{array}$ & $\begin{array}{l}- \\
- \\
- \\
- \\
- \\
-\end{array}$ & $\begin{array}{l}= \\
\overline{-} \\
\overline{-} \\
\overline{-} \\
\overline{-}\end{array}$ & $\begin{array}{r}52 \\
-1 \\
\overline{11} \\
1 \\
30 \\
5 \\
4\end{array}$ & $\begin{array}{r}35 \\
3 \\
4 \\
3 \\
11 \\
2 \\
6 \\
2 \\
4\end{array}$ \\
\hline $\begin{array}{l}\text { PACIFIC } \\
\text { Wash. } \\
\text { Oreg. } \\
\text { Calif. } \\
\text { Alaska } \\
\text { Hawaii }\end{array}$ & $\begin{array}{r}160 \\
29 \\
25 \\
99 \\
1 \\
6\end{array}$ & $\begin{array}{r}194 \\
16 \\
38 \\
133 \\
2 \\
5\end{array}$ & $\begin{array}{l}1 \\
1 \\
- \\
- \\
-\end{array}$ & $\begin{array}{l}2 \\
2 \\
= \\
- \\
-\end{array}$ & $\begin{array}{r}5 \\
4 \\
- \\
\\
1\end{array}$ & $\begin{array}{l}4 \\
4 \\
- \\
- \\
-\end{array}$ & $\begin{array}{l}\overline{-} \\
\overline{-} \\
\overline{-}\end{array}$ & $\begin{array}{l}= \\
\overline{-} \\
=\end{array}$ & $\begin{array}{r}154 \\
24 \\
25 \\
99 \\
1 \\
5\end{array}$ & $\begin{array}{r}188 \\
10 \\
38 \\
133 \\
2 \\
5\end{array}$ \\
\hline $\begin{array}{l}\text { Guam } \\
\text { P.R. } \\
\text { V.I. } \\
\text { Amer. Samoa } \\
\text { C.N.M.I. }\end{array}$ & $\begin{array}{l}\overline{4} \\
\overline{-} \\
-\end{array}$ & $\begin{array}{l}\overline{9} \\
\overline{-} \\
-\end{array}$ & $\begin{array}{l}\overline{-} \\
\overline{-} \\
\overline{-}\end{array}$ & $\begin{array}{l}\overline{-} \\
\bar{z} \\
\overline{-}\end{array}$ & $\begin{array}{l}\overline{-} \\
\bar{z} \\
\overline{-}\end{array}$ & $\begin{array}{l}- \\
z \\
-\end{array}$ & $\begin{array}{l}\bar{z} \\
\bar{z}\end{array}$ & $\begin{array}{l}- \\
z \\
-\end{array}$ & $\begin{array}{l}\overline{4} \\
\overline{-}\end{array}$ & $\begin{array}{l}\overline{9} \\
- \\
-\end{array}$ \\
\hline
\end{tabular}

$\mathrm{N}$ : Not notifiable. $\quad$ U: Unavailable. $\quad-$ : No reported cases. $\quad$ C.N.M.I.: Commonwealth of Northern Mariana Islands. ${ }^{*}$ Incidence data for reporting years 2004 and 2005 are provisional and cumulative (year-to-date). 
TABLE II. (Continued) Provisional cases of selected notifiable diseases, United States, weeks ending June 25, 2005, and June 26, 2004 (25th Week)*

\begin{tabular}{|c|c|c|c|c|c|c|c|c|c|c|}
\hline \multirow[b]{2}{*}{ Reporting area } & \multicolumn{2}{|c|}{ Pertussis } & \multicolumn{2}{|c|}{ Rabies, animal } & \multicolumn{2}{|c|}{$\begin{array}{l}\text { Rocky Mountain } \\
\text { spotted fever }\end{array}$} & \multicolumn{2}{|c|}{ Salmonellosis } & \multicolumn{2}{|c|}{ Shigellosis } \\
\hline & $\begin{array}{l}\text { Cum. } \\
2005\end{array}$ & $\begin{array}{l}\text { Cum. } \\
2004\end{array}$ & $\begin{array}{l}\text { Cum. } \\
2005\end{array}$ & $\begin{array}{l}\text { Cum. } \\
2004\end{array}$ & $\begin{array}{l}\text { Cum. } \\
2005\end{array}$ & $\begin{array}{l}\text { Cum. } \\
2004\end{array}$ & $\begin{array}{l}\text { Cum. } \\
2005\end{array}$ & $\begin{array}{l}\text { Cum. } \\
2004\end{array}$ & $\begin{array}{l}\text { Cum. } \\
2005\end{array}$ & $\begin{array}{l}\text { Cum. } \\
2004\end{array}$ \\
\hline UNITED STATES & 7,950 & 5,591 & 2,323 & 2,917 & 376 & 391 & 12,724 & 14,160 & 4,645 & 5,671 \\
\hline $\begin{array}{l}\text { NEW ENGLAND } \\
\text { Maine } \\
\text { N.H. } \\
\text { Vt. } \\
\text { Mass. } \\
\text { R.I. } \\
\text { Conn. }\end{array}$ & $\begin{array}{r}475 \\
13 \\
19 \\
55 \\
359 \\
11 \\
18\end{array}$ & $\begin{array}{r}748 \\
3 \\
24 \\
40 \\
640 \\
16 \\
25\end{array}$ & $\begin{array}{r}341 \\
26 \\
4 \\
27 \\
199 \\
8 \\
77\end{array}$ & $\begin{array}{r}244 \\
28 \\
10 \\
10 \\
98 \\
15 \\
83\end{array}$ & $\begin{array}{r}1 \\
\mathrm{~N} \\
- \\
- \\
1 \\
-\end{array}$ & $\begin{array}{r}8 \\
\mathrm{~N} \\
- \\
7 \\
1 \\
-\end{array}$ & $\begin{array}{r}833 \\
63 \\
56 \\
46 \\
451 \\
32 \\
185\end{array}$ & $\begin{array}{r}698 \\
35 \\
45 \\
21 \\
406 \\
48 \\
143\end{array}$ & $\begin{array}{r}104 \\
4 \\
4 \\
6 \\
60 \\
7 \\
23\end{array}$ & $\begin{array}{r}118 \\
2 \\
5 \\
2 \\
76 \\
8 \\
25\end{array}$ \\
\hline $\begin{array}{l}\text { MID. ATLANTIC } \\
\text { Upstate N.Y. } \\
\text { N.Y. City } \\
\text { N.J. } \\
\text { Pa. }\end{array}$ & $\begin{array}{r}705 \\
250 \\
44 \\
126 \\
285\end{array}$ & $\begin{array}{r}1,114 \\
808 \\
75 \\
78 \\
153\end{array}$ & $\begin{array}{r}279 \\
222 \\
14 \\
N \\
43\end{array}$ & $\begin{array}{r}363 \\
186 \\
9 \\
N \\
168\end{array}$ & $\begin{array}{r}24 \\
1 \\
8 \\
15\end{array}$ & $\begin{array}{r}34 \\
1 \\
12 \\
8 \\
13\end{array}$ & $\begin{array}{r}1,621 \\
448 \\
355 \\
260 \\
558\end{array}$ & $\begin{array}{r}1,847 \\
421 \\
536 \\
332 \\
558\end{array}$ & $\begin{array}{r}488 \\
122 \\
191 \\
140 \\
35\end{array}$ & $\begin{array}{r}596 \\
276 \\
172 \\
95 \\
53\end{array}$ \\
\hline $\begin{array}{l}\text { E.N. CENTRAL } \\
\text { Ohio } \\
\text { Ind. } \\
\text { Ill. } \\
\text { Mich. } \\
\text { Wis. }\end{array}$ & $\begin{array}{r}1,660 \\
663 \\
146 \\
190 \\
109 \\
552\end{array}$ & $\begin{array}{r}1,484 \\
201 \\
40 \\
303 \\
53 \\
887\end{array}$ & $\begin{array}{r}52 \\
25 \\
4 \\
15 \\
8 \\
-\end{array}$ & $\begin{array}{r}28 \\
8 \\
4 \\
9 \\
5 \\
2\end{array}$ & $\begin{array}{r}6 \\
4 \\
1 \\
1 \\
-\end{array}$ & $\begin{array}{r}14 \\
5 \\
3 \\
5 \\
1 \\
-\end{array}$ & $\begin{array}{r}1,532 \\
464 \\
147 \\
274 \\
340 \\
307\end{array}$ & $\begin{array}{r}2,029 \\
472 \\
191 \\
680 \\
350 \\
336\end{array}$ & $\begin{array}{r}313 \\
34 \\
33 \\
55 \\
124 \\
67\end{array}$ & $\begin{array}{r}428 \\
77 \\
92 \\
157 \\
50 \\
52\end{array}$ \\
\hline $\begin{array}{l}\text { W.N. CENTRAL } \\
\text { Minn. } \\
\text { lowa } \\
\text { Mo. } \\
\text { N. Dak. } \\
\text { S. Dak. } \\
\text { Nebr. } \\
\text { Kans. }\end{array}$ & $\begin{array}{r}1,141 \\
316 \\
324 \\
215 \\
48 \\
1 \\
107 \\
130\end{array}$ & $\begin{array}{r}344 \\
72 \\
42 \\
184 \\
10 \\
11 \\
5 \\
20\end{array}$ & $\begin{array}{r}170 \\
35 \\
32 \\
27 \\
6 \\
27 \\
43\end{array}$ & $\begin{array}{r}289 \\
23 \\
34 \\
12 \\
30 \\
59 \\
66 \\
65\end{array}$ & $\begin{array}{l}\frac{54}{-} \\
\frac{51}{2} \\
\frac{2}{1}\end{array}$ & $\begin{array}{l}\frac{43}{-} \\
\frac{38}{-} \\
\frac{5}{-}\end{array}$ & $\begin{array}{r}945 \\
223 \\
134 \\
315 \\
11 \\
60 \\
72 \\
130\end{array}$ & $\begin{array}{r}938 \\
226 \\
194 \\
257 \\
16 \\
35 \\
59 \\
151\end{array}$ & $\begin{array}{r}491 \\
29 \\
41 \\
346 \\
2 \\
15 \\
28 \\
30\end{array}$ & $\begin{array}{r}173 \\
23 \\
35 \\
75 \\
1 \\
6 \\
7 \\
26\end{array}$ \\
\hline $\begin{array}{l}\text { S. ATLANTIC } \\
\text { Del. } \\
\text { Md. } \\
\text { D.C. } \\
\text { Va. } \\
\text { W. Va. } \\
\text { N.C. } \\
\text { S.C. } \\
\text { Ga. } \\
\text { Fla. }\end{array}$ & $\begin{array}{r}521 \\
13 \\
90 \\
4 \\
91 \\
28 \\
41 \\
161 \\
15 \\
78\end{array}$ & $\begin{array}{r}296 \\
57 \\
6 \\
73 \\
4 \\
46 \\
49 \\
14 \\
47\end{array}$ & $\begin{array}{r}789 \\
141 \\
- \\
273 \\
19 \\
243 \\
5 \\
102 \\
6\end{array}$ & $\begin{array}{r}1,163 \\
9 \\
136 \\
- \\
220 \\
32 \\
321 \\
77 \\
163 \\
205\end{array}$ & $\begin{array}{r}202 \\
1 \\
22 \\
-9 \\
9 \\
3 \\
142 \\
6 \\
9 \\
10\end{array}$ & $\begin{array}{r}176 \\
2 \\
14 \\
2 \\
2 \\
1 \\
103 \\
20 \\
28 \\
6\end{array}$ & $\begin{array}{r}3,370 \\
27 \\
279 \\
20 \\
364 \\
52 \\
536 \\
161 \\
482 \\
1,449\end{array}$ & $\begin{array}{r}3,105 \\
24 \\
259 \\
17 \\
321 \\
62 \\
364 \\
242 \\
585 \\
1,231\end{array}$ & $\begin{array}{r}809 \\
4 \\
30 \\
8 \\
43 \\
84 \\
35 \\
204 \\
401\end{array}$ & $\begin{array}{r}1,371 \\
3 \\
51 \\
21 \\
49 \\
137 \\
246 \\
327 \\
537\end{array}$ \\
\hline $\begin{array}{l}\text { E.S. CENTRAL } \\
\text { Ky. } \\
\text { Tenn. } \\
\text { Ala. } \\
\text { Miss. }\end{array}$ & $\begin{array}{r}225 \\
63 \\
104 \\
40 \\
18\end{array}$ & $\begin{array}{l}71 \\
11 \\
39 \\
11 \\
10\end{array}$ & $\begin{array}{r}65 \\
7 \\
21 \\
37 \\
-\end{array}$ & $\begin{array}{r}64 \\
11 \\
22 \\
25 \\
6\end{array}$ & $\begin{array}{r}43 \\
31 \\
11 \\
1\end{array}$ & $\begin{array}{l}54 \\
29 \\
13 \\
12\end{array}$ & $\begin{array}{r}715 \\
142 \\
255 \\
230 \\
88\end{array}$ & $\begin{array}{l}881 \\
134 \\
244 \\
240 \\
263\end{array}$ & $\begin{array}{r}638 \\
105 \\
345 \\
152 \\
36\end{array}$ & $\begin{array}{r}315 \\
36 \\
140 \\
109 \\
30\end{array}$ \\
\hline $\begin{array}{l}\text { W.S. CENTRAL } \\
\text { Ark. } \\
\text { La. } \\
\text { Okla. } \\
\text { Tex. }\end{array}$ & $\begin{array}{r}227 \\
122 \\
20 \\
85\end{array}$ & $\begin{array}{r}261 \\
19 \\
9 \\
17 \\
216\end{array}$ & $\begin{array}{r}465 \\
18 \\
50 \\
397\end{array}$ & $\begin{array}{r}613 \\
27 \\
69 \\
517\end{array}$ & $\begin{array}{r}19 \\
12 \\
2 \\
5 \\
-\end{array}$ & $\begin{array}{r}52 \\
22 \\
3 \\
27 \\
-\end{array}$ & $\begin{array}{l}894 \\
271 \\
254 \\
140 \\
229\end{array}$ & $\begin{array}{r}1,508 \\
188 \\
288 \\
134 \\
898\end{array}$ & $\begin{array}{r}820 \\
29 \\
55 \\
357 \\
379\end{array}$ & $\begin{array}{r}1,635 \\
26 \\
168 \\
247 \\
1,194\end{array}$ \\
\hline $\begin{array}{l}\text { MOUNTAIN } \\
\text { Mont. } \\
\text { Idaho } \\
\text { Wyo. } \\
\text { Colo. } \\
\text { N. Mex. } \\
\text { Ariz. } \\
\text { Utah } \\
\text { Nev. }\end{array}$ & $\begin{array}{r}1,947 \\
371 \\
64 \\
18 \\
703 \\
62 \\
515 \\
189 \\
25\end{array}$ & $\begin{array}{r}510 \\
13 \\
18 \\
3 \\
264 \\
70 \\
99 \\
33 \\
10\end{array}$ & $\begin{array}{r}99 \\
- \\
12 \\
9 \\
78 \\
-\end{array}$ & $\begin{array}{r}56 \\
6 \\
- \\
7 \\
2 \\
41 \\
- \\
-\end{array}$ & $\begin{array}{r}22 \\
1 \\
1 \\
1 \\
2 \\
13 \\
4 \\
-\end{array}$ & $\begin{array}{l}7 \\
2 \\
1 \\
1 \\
1 \\
1 \\
1 \\
- \\
-\end{array}$ & $\begin{array}{r}843 \\
36 \\
49 \\
21 \\
212 \\
62 \\
286 \\
117 \\
60\end{array}$ & $\begin{array}{r}930 \\
64 \\
70 \\
22 \\
223 \\
101 \\
277 \\
93 \\
80\end{array}$ & $\begin{array}{r}271 \\
4 \\
2 \\
43 \\
31 \\
147 \\
19 \\
25\end{array}$ & $\begin{array}{r}343 \\
4 \\
6 \\
1 \\
57 \\
54 \\
175 \\
16 \\
20\end{array}$ \\
\hline $\begin{array}{l}\text { PACIFIC } \\
\text { Wash. } \\
\text { Oreg. } \\
\text { Calif. } \\
\text { Alaska } \\
\text { Hawaii }\end{array}$ & $\begin{array}{r}1,049 \\
234 \\
348 \\
390 \\
20 \\
57\end{array}$ & $\begin{array}{r}763 \\
224 \\
231 \\
289 \\
10 \\
9\end{array}$ & $\begin{array}{r}63 \\
2 \\
60 \\
1 \\
-\end{array}$ & $\begin{array}{r}97 \\
2 \\
84 \\
11 \\
-\end{array}$ & $\begin{array}{l}\frac{5}{-} \\
\frac{5}{-} \\
-\end{array}$ & $\begin{array}{l}3 \\
2 \\
1 \\
-\end{array}$ & $\begin{array}{r}1,971 \\
176 \\
143 \\
1,502 \\
21 \\
129\end{array}$ & $\begin{array}{r}2,224 \\
185 \\
190 \\
1,642 \\
31 \\
176\end{array}$ & $\begin{array}{r}711 \\
35 \\
34 \\
624 \\
5 \\
13\end{array}$ & $\begin{array}{r}692 \\
53 \\
32 \\
579 \\
5 \\
23\end{array}$ \\
\hline $\begin{array}{l}\text { Guam } \\
\text { P.R. } \\
\text { V.I. } \\
\text { Amer. Samoa } \\
\text { C.N.M.I. }\end{array}$ & $\begin{array}{l}\overline{1} \\
\bar{U} \\
-\end{array}$ & $\begin{array}{c}- \\
U \\
U\end{array}$ & $\frac{\overline{29}}{\bar{U}}$ & $\frac{\overline{25}}{U}$ & $\frac{\bar{N}}{\bar{U}}$ & $\frac{\bar{N}}{U}$ & $\begin{array}{l}\frac{79}{U} \\
-\end{array}$ & $\begin{array}{r}42 \\
154 \\
\cup \\
U\end{array}$ & $\begin{array}{l}-1 \\
\frac{U}{-}\end{array}$ & $\begin{array}{l}34 \\
12 \\
U \\
U\end{array}$ \\
\hline
\end{tabular}

$\mathrm{N}$ : Not notifiable. U: Unavailable.

* Incidence data for reporting years 2004 and 2005 are provisional and cumulative (year-to-date). 
TABLE II. (Continued) Provisional cases of selected notifiable diseases, United States, weeks ending June 25, 2005, and June 26, 2004 (25th Week)*

\begin{tabular}{|c|c|c|c|c|c|c|c|c|c|c|}
\hline \multirow[b]{4}{*}{ Reporting area } & \multirow{3}{*}{\multicolumn{2}{|c|}{$\begin{array}{c}\text { Streptococcal disease, } \\
\text { invasive, group A }\end{array}$}} & \multicolumn{4}{|c|}{ Streptococcus pneumoniae, invasive disease } & \multirow{2}{*}{\multicolumn{4}{|c|}{ Syphilis }} \\
\hline & & & \multirow{2}{*}{\multicolumn{2}{|c|}{$\begin{array}{l}\text { Drug resistant, } \\
\text { all ages }\end{array}$}} & \multirow{2}{*}{\multicolumn{2}{|c|}{ Age $<5$ years }} & & & & \\
\hline & & & & & & & \multicolumn{2}{|c|}{ Primary \& secondary } & \multicolumn{2}{|c|}{ Congenital } \\
\hline & $\begin{array}{l}\text { Cum. } \\
2005\end{array}$ & $\begin{array}{l}\text { Cum. } \\
2004\end{array}$ & $\begin{array}{l}\text { Cum. } \\
2005 \\
\end{array}$ & $\begin{array}{l}\text { Cum. } \\
2004 \\
\end{array}$ & $\begin{array}{l}\text { Cum. } \\
2005 \\
\end{array}$ & $\begin{array}{l}\text { Cum. } \\
2004 \\
\end{array}$ & $\begin{array}{l}\text { Cum. } \\
2005 \\
\end{array}$ & $\begin{array}{l}\text { Cum. } \\
2004\end{array}$ & $\begin{array}{l}\text { Cum. } \\
2005 \\
\end{array}$ & $\begin{array}{l}\text { Cum. } \\
2004 \\
\end{array}$ \\
\hline UNITED STATES & 2,389 & 2,673 & 1,314 & 1,310 & 463 & 440 & 3,538 & 3,613 & 113 & 201 \\
\hline $\begin{array}{l}\text { NEW ENGLAND } \\
\text { Maine } \\
\text { N.H. } \\
\text { Vt. } \\
\text { Mass. } \\
\text { R.I. } \\
\text { Conn. }\end{array}$ & $\begin{array}{r}89 \\
5 \\
7 \\
8 \\
62 \\
7 \\
-\end{array}$ & $\begin{array}{r}193 \\
5 \\
13 \\
7 \\
90 \\
17 \\
61\end{array}$ & $\begin{array}{r}14 \\
\mathrm{~N} \\
8 \\
6 \\
\mathrm{U}\end{array}$ & $\begin{array}{r}79 \\
\mathrm{~N} \\
6 \\
21 \\
7 \\
45\end{array}$ & $\begin{array}{r}\frac{48}{3} \\
3 \\
42 \\
\frac{U}{U}\end{array}$ & $\begin{array}{r}67 \\
2 \\
\mathrm{~N} \\
1 \\
39 \\
5 \\
20\end{array}$ & $\begin{array}{r}110 \\
1 \\
6 \\
80 \\
2 \\
21\end{array}$ & $\begin{array}{r}88 \\
2 \\
3 \\
52 \\
9 \\
22\end{array}$ & $\begin{array}{l}- \\
- \\
- \\
-\end{array}$ & $\begin{array}{l}- \\
- \\
- \\
-\end{array}$ \\
\hline $\begin{array}{l}\text { MID. ATLANTIC } \\
\text { Upstate N.Y. } \\
\text { N.Y. City } \\
\text { N.J. } \\
\text { Pa. }\end{array}$ & $\begin{array}{r}556 \\
179 \\
95 \\
116 \\
166\end{array}$ & $\begin{array}{r}469 \\
145 \\
76 \\
102 \\
146\end{array}$ & $\begin{array}{r}132 \\
50 \\
U \\
N \\
82\end{array}$ & $\begin{array}{r}99 \\
44 \\
\mathrm{U} \\
\mathrm{N} \\
55\end{array}$ & $\begin{array}{l}92 \\
43 \\
17 \\
14 \\
18\end{array}$ & $\begin{array}{r}65 \\
43 \\
U \\
5 \\
17\end{array}$ & $\begin{array}{r}466 \\
35 \\
300 \\
63 \\
68\end{array}$ & $\begin{array}{r}462 \\
39 \\
275 \\
83 \\
65\end{array}$ & $\begin{array}{r}12 \\
6 \\
5 \\
1 \\
-\end{array}$ & $\begin{array}{r}22 \\
1 \\
9 \\
11 \\
1\end{array}$ \\
\hline $\begin{array}{l}\text { E.N. CENTRAL } \\
\text { Ohio } \\
\text { Ind. } \\
\text { III. } \\
\text { Mich. } \\
\text { Wis. }\end{array}$ & $\begin{array}{r}462 \\
122 \\
49 \\
100 \\
183 \\
8\end{array}$ & $\begin{array}{r}628 \\
152 \\
69 \\
175 \\
182 \\
50\end{array}$ & $\begin{array}{r}355 \\
230 \\
118 \\
7 \\
N\end{array}$ & $\begin{array}{r}309 \\
223 \\
86 \\
\mathrm{~N} \\
\mathrm{~N}\end{array}$ & $\begin{array}{r}122 \\
53 \\
31 \\
34 \\
4\end{array}$ & $\begin{array}{r}111 \\
54 \\
22 \\
1 \\
\mathrm{~N} \\
34\end{array}$ & $\begin{array}{r}325 \\
99 \\
33 \\
148 \\
35 \\
10\end{array}$ & $\begin{array}{r}432 \\
117 \\
27 \\
170 \\
98 \\
20\end{array}$ & $\begin{array}{r}19 \\
2 \\
1 \\
5 \\
9 \\
2\end{array}$ & $\begin{array}{r}27 \\
1 \\
1 \\
3 \\
22 \\
\end{array}$ \\
\hline $\begin{array}{l}\text { W.N. CENTRAL } \\
\text { Minn. } \\
\text { lowa } \\
\text { Mo. } \\
\text { N. Dak. } \\
\text { S. Dak. } \\
\text { Nebr. } \\
\text { Kans. }\end{array}$ & $\begin{array}{r}156 \\
58 \\
N \\
46 \\
2 \\
16 \\
11 \\
23\end{array}$ & $\begin{array}{r}190 \\
89 \\
\mathrm{~N} \\
42 \\
9 \\
8 \\
14 \\
28\end{array}$ & $\begin{array}{l}32 \\
\mathrm{~N} \\
27 \\
- \\
3 \\
2 \\
\mathrm{~N}\end{array}$ & $\begin{array}{l}\frac{13}{N} \\
\frac{10}{3} \\
\frac{3}{N}\end{array}$ & $\begin{array}{r}51 \\
29 \\
5 \\
1 \\
6 \\
10\end{array}$ & $\begin{array}{r}42 \\
25 \\
\mathrm{~N} \\
8 \\
1 \\
- \\
5 \\
3\end{array}$ & $\begin{array}{r}120 \\
30 \\
1 \\
74 \\
- \\
3 \\
12\end{array}$ & $\begin{array}{r}91 \\
16 \\
4 \\
52 \\
- \\
5 \\
14\end{array}$ & $\begin{array}{l}1 \\
- \\
1 \\
- \\
- \\
-\end{array}$ & $\begin{array}{l}2 \\
1 \\
1 \\
- \\
-\end{array}$ \\
\hline $\begin{array}{l}\text { S. ATLANTIC } \\
\text { Del. } \\
\text { Md. } \\
\text { D.C. } \\
\text { Va. } \\
\text { W. Va. } \\
\text { N.C. } \\
\text { S.C. } \\
\text { Ga. } \\
\text { Fla. }\end{array}$ & $\begin{array}{r}491 \\
125 \\
6 \\
44 \\
11 \\
79 \\
11 \\
83 \\
132\end{array}$ & $\begin{array}{r}529 \\
2 \\
82 \\
5 \\
41 \\
16 \\
80 \\
43 \\
134 \\
126\end{array}$ & $\begin{array}{r}536 \\
1 \\
14 \\
\mathrm{~N} \\
69 \\
\mathrm{~N} \\
- \\
109 \\
343\end{array}$ & $\begin{array}{r}667 \\
4 \\
5 \\
5 \\
N \\
66 \\
N \\
76 \\
165 \\
351\end{array}$ & $\begin{array}{r}55 \\
36 \\
2 \\
\frac{17}{U} \\
- \\
-\end{array}$ & $\begin{array}{r}31 \\
N \\
20 \\
4 \\
N \\
7 \\
U \\
N \\
N \\
N\end{array}$ & $\begin{array}{r}899 \\
6 \\
171 \\
56 \\
50 \\
2 \\
109 \\
30 \\
121 \\
354\end{array}$ & $\begin{array}{r}888 \\
3 \\
169 \\
25 \\
49 \\
3 \\
79 \\
61 \\
153 \\
346\end{array}$ & $\begin{array}{l}\frac{24}{8} \\
\frac{8}{3} \\
\frac{7}{7} \\
\frac{1}{5}\end{array}$ & $\begin{array}{r}36 \\
1 \\
5 \\
1 \\
1 \\
4 \\
9 \\
2 \\
13\end{array}$ \\
\hline $\begin{array}{l}\text { E.S. CENTRAL } \\
\text { Ky. } \\
\text { Tenn. } \\
\text { Ala. } \\
\text { Miss. }\end{array}$ & $\begin{array}{r}108 \\
23 \\
85 \\
- \\
-\end{array}$ & $\begin{array}{r}139 \\
44 \\
95 \\
- \\
\end{array}$ & $\begin{array}{r}114 \\
21 \\
93 \\
- \\
-\end{array}$ & $\begin{array}{r}86 \\
20 \\
64 \\
2\end{array}$ & $\begin{array}{l}5 \\
\mathrm{~N} \\
- \\
5\end{array}$ & $\begin{array}{r}9 \\
N \\
N \\
N \\
9\end{array}$ & $\begin{array}{r}202 \\
17 \\
89 \\
80 \\
16\end{array}$ & $\begin{array}{r}193 \\
23 \\
67 \\
83 \\
20\end{array}$ & $\begin{array}{l}\frac{12}{8} \\
3 \\
1\end{array}$ & $\begin{array}{l}9 \\
1 \\
1 \\
5 \\
2\end{array}$ \\
\hline $\begin{array}{l}\text { W.S. CENTRAL } \\
\text { Ark. } \\
\text { La. } \\
\text { Okla. } \\
\text { Tex. }\end{array}$ & $\begin{array}{r}97 \\
8 \\
6 \\
69 \\
14\end{array}$ & $\begin{array}{r}203 \\
7 \\
2 \\
39 \\
155\end{array}$ & $\begin{array}{r}87 \\
12 \\
75 \\
N \\
N\end{array}$ & $\begin{array}{r}42 \\
6 \\
36 \\
N \\
N\end{array}$ & $\begin{array}{r}56 \\
13 \\
18 \\
16 \\
9\end{array}$ & $\begin{array}{r}87 \\
7 \\
20 \\
26 \\
34\end{array}$ & $\begin{array}{r}594 \\
26 \\
123 \\
21 \\
424\end{array}$ & $\begin{array}{r}557 \\
17 \\
134 \\
13 \\
393\end{array}$ & $\begin{array}{r}27 \\
3 \\
1 \\
23\end{array}$ & $\begin{array}{r}41 \\
3 \\
3 \\
2 \\
33\end{array}$ \\
\hline $\begin{array}{l}\text { MOUNTAIN } \\
\text { Mont. } \\
\text { Idaho } \\
\text { Wyo. } \\
\text { Colo. } \\
\text { N. Mex. } \\
\text { Ariz. } \\
\text { Utah } \\
\text { Nev. }\end{array}$ & $\begin{array}{r}377 \\
1 \\
2 \\
140 \\
23 \\
162 \\
48 \\
1\end{array}$ & $\begin{array}{r}277 \\
5 \\
6 \\
61 \\
64 \\
116 \\
24 \\
1\end{array}$ & $\begin{array}{r}44 \\
N \\
18 \\
N \\
N \\
25 \\
1\end{array}$ & $\begin{array}{l}14 \\
N \\
5 \\
N \\
N \\
N \\
7 \\
2\end{array}$ & $\begin{array}{l}33 \\
- \\
\frac{-}{32} \\
- \\
\frac{1}{-}\end{array}$ & $\begin{array}{l}\frac{28}{N} \\
\frac{N}{28} \\
\frac{N}{-} \\
-\end{array}$ & $\begin{array}{r}183 \\
5 \\
19 \\
19 \\
23 \\
68 \\
4 \\
45\end{array}$ & $\begin{array}{r}193 \\
1 \\
13 \\
1 \\
36 \\
49 \\
80 \\
3 \\
10\end{array}$ & $\begin{array}{r}14 \\
\frac{1}{-} \\
-1 \\
12 \\
-\end{array}$ & $\begin{array}{l}27 \\
2 \\
- \\
2 \\
23 \\
-\end{array}$ \\
\hline $\begin{array}{l}\text { PACIFIC } \\
\text { Wash. } \\
\text { Oreg. } \\
\text { Calif. } \\
\text { Alaska } \\
\text { Hawaii }\end{array}$ & $\begin{array}{r}53 \\
N \\
N \\
- \\
53\end{array}$ & $\begin{array}{r}45 \\
N \\
N \\
- \\
45\end{array}$ & $\begin{array}{l}\bar{N} \\
N \\
N \\
-\end{array}$ & $\begin{array}{r}1 \\
N \\
N \\
N \\
1\end{array}$ & $\begin{array}{r}1 \\
\mathrm{~N} \\
\mathrm{~N} \\
\\
1\end{array}$ & $\begin{array}{l}\bar{N} \\
N \\
N \\
N \\
-\end{array}$ & $\begin{array}{r}639 \\
64 \\
16 \\
553 \\
4 \\
2\end{array}$ & $\begin{array}{r}709 \\
42 \\
16 \\
648 \\
3\end{array}$ & $\begin{array}{c}4 \\
- \\
- \\
-\end{array}$ & $\begin{array}{l}37 \\
- \\
- \\
-\end{array}$ \\
\hline $\begin{array}{l}\text { Guam } \\
\text { P.R. } \\
\text { V.I. } \\
\text { Amer. Samoa } \\
\text { C.N.M.I. }\end{array}$ & $\frac{\bar{N}}{\bar{U}}$ & $\frac{\bar{N}}{U}$ & $\frac{\bar{N}}{U}$ & $\frac{\bar{N}}{U}$ & $\frac{-}{\bar{U}}$ & $\frac{\bar{N}}{U}$ & $\begin{array}{l}\frac{-}{91} \\
-\end{array}$ & $\begin{array}{r}1 \\
69 \\
4 \\
\cup \\
\cup\end{array}$ & $\frac{\overline{6}}{\underline{U}}$ & $\begin{array}{l} \\
U \\
U\end{array}$ \\
\hline
\end{tabular}

$\mathrm{N}$ : Not notifiable. U: Unavailable. 
TABLE II. (Continued) Provisional cases of selected notifiable diseases, United States, weeks ending June 25, 2005, and June 26, 2004 (25th Week)*

\begin{tabular}{|c|c|c|c|c|c|c|c|c|c|}
\hline \multirow[b]{3}{*}{ Reporting area } & \multirow{2}{*}{\multicolumn{2}{|c|}{ Tuberculosis }} & \multirow{2}{*}{\multicolumn{2}{|c|}{ Typhoid fever }} & \multirow{2}{*}{\multicolumn{2}{|c|}{$\begin{array}{c}\text { Varicella } \\
\text { (chickenpox) }\end{array}$}} & \multicolumn{3}{|c|}{ West Nile virus disease $^{\dagger}$} \\
\hline & & & & & & & $\mathrm{Net}$ & & Non-neuroinvasive \\
\hline & $\begin{array}{l}\text { Cum. } \\
2005\end{array}$ & $\begin{array}{l}\text { Cum. } \\
2004 \\
\end{array}$ & $\begin{array}{l}\text { Cum. } \\
2005\end{array}$ & $\begin{array}{l}\text { Cum. } \\
2004\end{array}$ & $\begin{array}{l}\text { Cum. } \\
2005\end{array}$ & $\begin{array}{l}\text { Cum. } \\
2004 \\
\end{array}$ & $\begin{array}{l}\text { Cum. } \\
2005\end{array}$ & $\begin{array}{l}\text { Cum. } \\
2004\end{array}$ & \begin{tabular}{|l|} 
Cum. \\
2005 \\
\end{tabular} \\
\hline UNITED STATES & 4,501 & 6,087 & 97 & 127 & 12,795 & 12,359 & - & 63 & - \\
\hline $\begin{array}{l}\text { NEW ENGLAND } \\
\text { Maine } \\
\text { N.H. } \\
\text { Vt. } \\
\text { Mass. } \\
\text { R.I. } \\
\text { Conn. }\end{array}$ & $\begin{array}{r}146 \\
8 \\
4 \\
97 \\
14 \\
23\end{array}$ & $\begin{array}{r}199 \\
11 \\
7 \\
-114 \\
23 \\
44\end{array}$ & $\begin{array}{r}11 \\
\frac{1}{-} \\
\frac{7}{3}\end{array}$ & $\begin{array}{r}14 \\
\overline{-} \\
\overline{12} \\
1 \\
1\end{array}$ & $\begin{array}{r}920 \\
200 \\
151 \\
31 \\
538 \\
U\end{array}$ & $\begin{array}{r}1,774 \\
177 \\
-\overline{399} \\
41 \\
-157\end{array}$ & $\begin{array}{l}- \\
= \\
= \\
=\end{array}$ & $\begin{array}{l}= \\
= \\
= \\
=\end{array}$ & $\begin{array}{l}= \\
= \\
= \\
=\end{array}$ \\
\hline $\begin{array}{l}\text { MID. ATLANTIC } \\
\text { Upstate N.Y. } \\
\text { N.Y. City } \\
\text { N.J. } \\
\text { Pa. }\end{array}$ & $\begin{array}{l}946 \\
117 \\
483 \\
221 \\
125\end{array}$ & $\begin{array}{l}893 \\
114 \\
454 \\
192 \\
133\end{array}$ & $\begin{array}{r}25 \\
4 \\
6 \\
8 \\
7\end{array}$ & $\begin{array}{r}34 \\
2 \\
13 \\
11 \\
8\end{array}$ & $\begin{array}{r}2,804 \\
\overline{-} \\
2,804\end{array}$ & $\begin{array}{l}58 \\
- \\
58\end{array}$ & $\begin{array}{l}- \\
- \\
-\end{array}$ & $\frac{\frac{2}{1}}{\frac{1}{1}}$ & $\begin{array}{l}- \\
- \\
-\end{array}$ \\
\hline $\begin{array}{l}\text { E.N. CENTRAL } \\
\text { Ohio } \\
\text { Ind. } \\
\text { III. } \\
\text { Mich. } \\
\text { Wis. }\end{array}$ & $\begin{array}{r}599 \\
122 \\
64 \\
283 \\
92 \\
38\end{array}$ & $\begin{array}{r}533 \\
97 \\
66 \\
240 \\
94 \\
36\end{array}$ & $\begin{array}{l}5 \\
- \\
1 \\
2 \\
2\end{array}$ & $\begin{array}{r}13 \\
2 \\
-6 \\
4 \\
1\end{array}$ & $\begin{array}{r}3,833 \\
862 \\
120 \\
24 \\
2,572 \\
255\end{array}$ & $\begin{array}{r}3,890 \\
962 \\
N \\
1 \\
2,459 \\
468\end{array}$ & $\begin{array}{l}- \\
- \\
- \\
-\end{array}$ & $\begin{array}{l}\frac{1}{-} \\
-1 \\
-\end{array}$ & $\begin{array}{l}- \\
- \\
- \\
-\end{array}$ \\
\hline $\begin{array}{l}\text { W.N. CENTRAL } \\
\text { Minn. } \\
\text { lowa } \\
\text { Mo. } \\
\text { N. Dak. } \\
\text { S. Dak. } \\
\text { Nebr. } \\
\text { Kans. }\end{array}$ & $\begin{array}{r}209 \\
87 \\
17 \\
56 \\
2 \\
6 \\
13 \\
28\end{array}$ & $\begin{array}{r}204 \\
75 \\
19 \\
58 \\
3 \\
5 \\
11 \\
33\end{array}$ & $\begin{array}{l}2 \\
2 \\
= \\
= \\
= \\
=\end{array}$ & $\begin{array}{l}3 \\
2 \\
1 \\
- \\
= \\
-\end{array}$ & $\begin{array}{r}199 \\
\mathrm{~N} \\
125 \\
10 \\
64 \\
-\end{array}$ & $\begin{array}{r}128 \\
\mathrm{~N} \\
2 \\
71 \\
55 \\
- \\
-\end{array}$ & $\begin{array}{l}= \\
= \\
= \\
= \\
=\end{array}$ & $\begin{array}{l}\frac{2}{7} \\
\frac{1}{1} \\
\frac{1}{-}\end{array}$ & $\begin{array}{l}\bar{z} \\
\bar{z} \\
\bar{z} \\
\overline{\mathrm{N}}\end{array}$ \\
\hline $\begin{array}{l}\text { S. ATLANTIC } \\
\text { Del. } \\
\text { Md. } \\
\text { D.C. } \\
\text { Va. } \\
\text { W. Va. } \\
\text { N.C. } \\
\text { S.C. } \\
\text { Ga. } \\
\text { Fla. }\end{array}$ & $\begin{array}{r}996 \\
2 \\
112 \\
28 \\
122 \\
10 \\
98 \\
100 \\
149 \\
375\end{array}$ & $\begin{array}{r}1,240 \\
12 \\
118 \\
4 \\
91 \\
11 \\
126 \\
98 \\
310 \\
470\end{array}$ & $\begin{array}{l}\frac{13}{3} \\
\frac{3}{2} \\
\frac{2}{2} \\
3\end{array}$ & $\begin{array}{l}\frac{14}{5} \\
\frac{-3}{3} \\
\frac{3}{3} \\
\frac{1}{2}\end{array}$ & $\begin{array}{r}1,040 \\
10 \\
-16 \\
209 \\
628 \\
\frac{1}{177} \\
- \\
-\end{array}$ & $\begin{array}{r}1,444 \\
4 \\
-17 \\
343 \\
804 \\
N \\
276 \\
- \\
-\end{array}$ & $\begin{array}{l}- \\
= \\
= \\
= \\
= \\
=\end{array}$ & $\begin{array}{l}1 \\
= \\
= \\
= \\
\overline{-} \\
\overline{1}\end{array}$ & $\begin{array}{l}- \\
\overline{-} \\
\overline{-} \\
= \\
= \\
=\end{array}$ \\
\hline $\begin{array}{l}\text { E.S. CENTRAL } \\
\text { Ky. } \\
\text { Tenn. } \\
\text { Ala. } \\
\text { Miss. }\end{array}$ & $\begin{array}{r}247 \\
52 \\
106 \\
89 \\
-\end{array}$ & $\begin{array}{r}272 \\
47 \\
100 \\
92 \\
33\end{array}$ & $\begin{array}{l}1 \\
1 \\
- \\
-\end{array}$ & $\begin{array}{r}5 \\
2 \\
3 \\
- \\
-\end{array}$ & $\begin{array}{l}\bar{N} \\
- \\
-\end{array}$ & $\begin{array}{l}\bar{N} \\
\overline{-} \\
-\end{array}$ & $\begin{array}{l}- \\
z \\
-\end{array}$ & $\begin{array}{l}\frac{1}{-} \\
\frac{1}{-}\end{array}$ & $\begin{array}{l}- \\
\bar{z} \\
-\end{array}$ \\
\hline $\begin{array}{l}\text { W.S. CENTRAL } \\
\text { Ark. } \\
\text { La. } \\
\text { Okla. } \\
\text { Tex. }\end{array}$ & $\begin{array}{r}424 \\
49 \\
65 \\
310\end{array}$ & $\begin{array}{r}1,014 \\
61 \\
\frac{77}{876}\end{array}$ & $\frac{3}{-}$ & $\frac{9}{-}$ & $\frac{101}{2,379}$ & $\frac{3,579}{\frac{45}{-}}$ & $\begin{array}{l}- \\
- \\
-\end{array}$ & $\frac{2}{-}$ & $\begin{array}{l}- \\
\bar{z} \\
-\end{array}$ \\
\hline $\begin{array}{l}\text { MOUNTAIN } \\
\text { Mont. } \\
\text { Idaho } \\
\text { Wyo. } \\
\text { Colo. } \\
\text { N. Mex. } \\
\text { Ariz. } \\
\text { Utah } \\
\text { Nev. }\end{array}$ & $\begin{array}{r}156 \\
6 \\
- \\
27 \\
8 \\
104 \\
11 \\
-\end{array}$ & $\begin{array}{r}254 \\
4 \\
1 \\
66 \\
18 \\
103 \\
20 \\
42\end{array}$ & $\begin{array}{l}3 \\
\overline{-} \\
- \\
- \\
\overline{1} \\
1 \\
1\end{array}$ & $\begin{array}{l}6 \\
\overline{-} \\
\overline{1} \\
\frac{1}{2} \\
1 \\
2\end{array}$ & $\begin{array}{r}1,620 \\
- \\
\overline{43} \\
1,157 \\
97 \\
- \\
323 \\
-\end{array}$ & $\begin{array}{r}1,486 \\
- \\
\overline{22} \\
1,170 \\
\cup \\
\frac{U}{294} \\
-\end{array}$ & $\begin{array}{l}- \\
= \\
= \\
= \\
= \\
-\end{array}$ & $\begin{array}{l}\frac{52}{-} \\
- \\
\frac{1}{51} \\
-\end{array}$ & $\begin{array}{l}- \\
= \\
= \\
= \\
= \\
=\end{array}$ \\
\hline $\begin{array}{l}\text { PACIFIC } \\
\text { Wash. } \\
\text { Oreg. } \\
\text { Calif. } \\
\text { Alaska } \\
\text { Hawaii }\end{array}$ & $\begin{array}{r}778 \\
98 \\
50 \\
564 \\
13 \\
53\end{array}$ & $\begin{array}{r}1,478 \\
115 \\
39 \\
1,257 \\
15 \\
52\end{array}$ & $\begin{array}{r}34 \\
2 \\
2 \\
24 \\
6\end{array}$ & $\begin{array}{r}29 \\
\frac{2}{21} \\
\frac{21}{6}\end{array}$ & $\begin{array}{l}\bar{N} \\
- \\
- \\
-\end{array}$ & $\begin{array}{l}\bar{N} \\
- \\
- \\
-\end{array}$ & $\begin{array}{l}- \\
= \\
- \\
-\end{array}$ & $\begin{array}{l}\frac{2}{-} \\
\frac{2}{-}\end{array}$ & $\begin{array}{l}- \\
= \\
= \\
-\end{array}$ \\
\hline $\begin{array}{l}\text { Guam } \\
\text { P.R. } \\
\text { V.I. } \\
\text { Amer. Samoa } \\
\text { C.N.M.I. }\end{array}$ & $\begin{array}{l}- \\
\bar{u} \\
-\end{array}$ & $\begin{array}{l}36 \\
21 \\
U \\
U\end{array}$ & $\begin{array}{l}\overline{-} \\
\bar{u}\end{array}$ & $\begin{array}{c}\overline{-} \\
\bar{u} \\
U\end{array}$ & $\frac{\overline{96}}{\bar{U}}$ & $\begin{array}{r}82 \\
242 \\
U \\
U\end{array}$ & $\begin{array}{l}- \\
\bar{u} \\
-\end{array}$ & $\begin{array}{l}\bar{z} \\
\bar{U} \\
U\end{array}$ & $\begin{array}{l}- \\
= \\
=\end{array}$ \\
\hline
\end{tabular}

$\mathrm{N}:$ Not notifiable. U: Unavailable.

C.N.M.I.: Commonwealth of Northern Mariana Islands.

* Incidence data for reporting years 2004 and 2005 are provisional and cumulative (year-to-date).

${ }^{\dagger}$ Updated weekly from reports to the Division of Vector-Borne Infectious Diseases, National Center for Infectious Diseases (ArboNet Surveillance).

s Not previously notifiable. 
TABLE III. Deaths in 122 U.S. cities, ${ }^{\star}$ week ending June 25, 2005 (25th Week)

\begin{tabular}{|c|c|c|c|c|c|c|c|c|c|c|c|c|c|c|c|}
\hline & \multicolumn{6}{|c|}{ All causes, by age (years) } & & & \multicolumn{6}{|c|}{ All causes, by age (years) } & \multirow[b]{2}{*}{$\begin{array}{l}\text { P\&I }{ }^{\dagger} \\
\text { Total }\end{array}$} \\
\hline Reporting Area & $\begin{array}{c}\text { All } \\
\text { Ages }\end{array}$ & $\geq 65$ & $45-64$ & 25-44 & $1-24$ & $<1$ & $\begin{array}{l}\text { P\&I }^{\dagger} \\
\text { Total }\end{array}$ & Reporting Area & $\begin{array}{c}\text { All } \\
\text { Ages }\end{array}$ & $\geq 65$ & $45-64$ & 25-44 & $1-24$ & $<1$ & \\
\hline NEW ENGLAND & 403 & 272 & 74 & 29 & 15 & 13 & 21 & S. ATLANTIC & 984 & 610 & 240 & 83 & 30 & 21 & 42 \\
\hline Boston, Mass. & 127 & 82 & 23 & 8 & 9 & 5 & 7 & Atlanta, Ga. & U & U & U & U & U & U & U \\
\hline Bridgeport, Conn. & 26 & 14 & 6 & 2 & 3 & 1 & 2 & Baltimore, Md. & 147 & 86 & 41 & 13 & 3 & 4 & 13 \\
\hline Cambridge, Mass. & 13 & 12 & 1 & - & - & - & - & Charlotte, N.C. & 81 & 55 & 15 & 8 & 2 & 1 & 4 \\
\hline Fall River, Mass. & 21 & 17 & 1 & 3 & - & - & - & Jacksonville, Fla. & 148 & 96 & 30 & 12 & 5 & 5 & 1 \\
\hline Hartford, Conn. & 49 & 34 & 11 & 1 & - & 3 & 3 & Miami, Fla. & 120 & 76 & 19 & 17 & 7 & 1 & 5 \\
\hline Lowell, Mass. & 17 & 12 & 3 & 2 & - & - & - & Norfolk, Va. & 55 & 34 & 18 & 2 & 1 & - & - \\
\hline Lynn, Mass. & 8 & 4 & 2 & 2 & - & - & 1 & Richmond, Va. & 43 & 25 & 11 & 5 & 2 & - & 1 \\
\hline New Bedford, Mass. & 25 & 19 & 3 & 3 & - & 一 & 2 & Savannah, Ga. & 55 & 34 & 13 & 3 & 2 & 3 & 3 \\
\hline New Haven, Conn. & 17 & 10 & 1 & 5 & 1 & - & 2 & St. Petersburg, Fla. & 53 & 38 & 8 & 5 & 1 & 1 & 2 \\
\hline Providence, R.I. & 55 & 40 & 11 & 1 & 2 & 1 & 2 & Tampa, Fla. & 158 & 87 & 51 & 12 & 2 & 6 & 10 \\
\hline Somerville, Mass. & U & U & U & U & $\mathrm{U}$ & U & $\bar{U}$ & Washington, D.C. & 100 & 63 & 29 & 4 & 4 & - & 2 \\
\hline Springfield, Mass. & $U$ & $U$ & $U$ & $U$ & U & U & $U$ & Wilmington, Del. & 24 & 16 & 5 & 2 & 1 & - & 1 \\
\hline Waterbury, Conn. & U & U & $U$ & $U$ & U & U & U & & 884 & 585 & 205 & 56 & 22 & 16 & 60 \\
\hline Worcester, Mass. & 45 & 28 & 12 & 2 & - & 3 & 2 & $\begin{array}{l}\text { Birmingham, Ala. } \\
\text { Bir. }\end{array}$ & $\begin{array}{l}884 \\
228\end{array}$ & $\begin{array}{l}585 \\
154\end{array}$ & $\begin{array}{r}205 \\
52\end{array}$ & $\begin{array}{l}50 \\
14\end{array}$ & $\begin{array}{r}22 \\
6\end{array}$ & 2 & 18 \\
\hline MID. ATLANTIC & 1,883 & 1,254 & 439 & 106 & 42 & 39 & 94 & Chattanooga, Tenn. & 85 & 61 & 16 & 5 & 1 & 2 & 6 \\
\hline Albany, N.Y. & 38 & 30 & 3 & 1 & 2 & 2 & 3 & Knoxville, Tenn. & 98 & 69 & 20 & 6 & 2 & 1 & 6 \\
\hline Allentown, $\mathrm{Pa}$. & 32 & 23 & 6 & 1 & 2 & - & 2 & Lexington, Ky. & 83 & 54 & 21 & 4 & 1 & 3 & 4 \\
\hline Buffalo, N.Y. & 78 & 57 & 14 & 4 & 2 & 1 & 6 & Memphis, Tenn. & 140 & 88 & 35 & 7 & 7 & 3 & 6 \\
\hline Camden, N.J. & 25 & 11 & 6 & 4 & 3 & 1 & - & Mobile, Ala. & 55 & 32 & 15 & 5 & 2 & 1 & 2 \\
\hline Elizabeth, N.J. & 19 & 15 & 3 & 1 & - & - & 2 & Montgomery, Ala. & 65 & 51 & 11 & 3 & - & - & 6 \\
\hline Erie, $\mathrm{Pa}$. & 50 & 36 & 10 & 2 & 2 & 一 & 1 & Nashville, Tenn. & 130 & 76 & 35 & 12 & 3 & 4 & 12 \\
\hline Jersey City, N.J. & 44 & 28 & 15 & 1 & - & - & - & W. S. CENTRAL & 1488 & 925 & 365 & 102 & 52 & 44 & 65 \\
\hline New York City, N.Y. & 1,094 & 750 & 248 & 57 & 14 & 22 & 47 & $\begin{array}{l}\text { W.S. CENIRAL } \\
\text { Austin, Tex. }\end{array}$ & $\begin{array}{r}1,400 \\
36\end{array}$ & $\begin{array}{r}y<3 \\
28\end{array}$ & $\begin{array}{r}305 \\
5\end{array}$ & 102 & 1 & $\begin{array}{r}44 \\
1\end{array}$ & $\begin{array}{r}65 \\
1\end{array}$ \\
\hline Newark, N.J. & 48 & 21 & 16 & 5 & 5 & 1 & 2 & $\begin{array}{l}\text { Austın, lex. } \\
\text { Baton Rouge, La. }\end{array}$ & 30 & $\begin{array}{l}<0 \\
22\end{array}$ & 7 & 1 & - & - & - \\
\hline Paterson, N.J. & U & U & U & U & U & U & $\bar{U}$ & $\begin{array}{l}\text { Baton Rouge, La. } \\
\text { Corpus Christi, Tex. }\end{array}$ & 48 & $\begin{array}{l}22 \\
37\end{array}$ & 9 & 1 & - & $\overline{1}$ & $\overline{3}$ \\
\hline Philadelphia, Pa. & 264 & 159 & 71 & 16 & 11 & 7 & 17 & $\begin{array}{l}\text { Corpus Christı, Iex. } \\
\text { Dallas. Tex. }\end{array}$ & $\begin{array}{r}40 \\
188\end{array}$ & $\begin{array}{r}31 \\
105\end{array}$ & 54 & 17 & $\overline{6}$ & 6 & $\begin{array}{l}3 \\
8\end{array}$ \\
\hline Pittsburgh, $\mathrm{Pa} .^{\S}$ & 23 & 13 & 7 & 1 & 1 & 1 & 1 & $\begin{array}{l}\text { Dallas, Iex. } \\
\text { El Paso. Tex }\end{array}$ & $\begin{array}{r}188 \\
96\end{array}$ & $\begin{array}{r}105 \\
64\end{array}$ & $\begin{array}{l}54 \\
20\end{array}$ & 4 & $\begin{array}{l}0 \\
6\end{array}$ & $\begin{array}{l}0 \\
2\end{array}$ & $\begin{array}{l}8 \\
1\end{array}$ \\
\hline Reading, $\mathrm{Pa}$. & 23 & 12 & 7 & 3 & - & 1 & 3 & El Paso, lex. & $\begin{array}{r}90 \\
126\end{array}$ & $\begin{array}{l}64 \\
75\end{array}$ & 20 & $\begin{array}{r}4 \\
12\end{array}$ & $\begin{array}{l}0 \\
7\end{array}$ & $\begin{array}{l}2 \\
6\end{array}$ & $\begin{array}{l}1 \\
1\end{array}$ \\
\hline Rochester, N.Y. & U & U & U & $\mathrm{U}$ & U & U & $U$ & Ft. Worth, Tex. & 120 & $\begin{array}{r}15 \\
181\end{array}$ & $\begin{array}{l}20 \\
81\end{array}$ & $\begin{array}{l}12 \\
27\end{array}$ & 8 & 6 & $\begin{array}{r}1 \\
16\end{array}$ \\
\hline Schenectady, N.Y. & 13 & 9 & 3 & 1 & - & - & 1 & Houston, Tex. & $\begin{array}{r}303 \\
79\end{array}$ & 48 & $\begin{array}{l}81 \\
24\end{array}$ & $\begin{array}{r}27 \\
3\end{array}$ & 8 & 6 & $\begin{array}{r}16 \\
2\end{array}$ \\
\hline Scranton, Pa. & U & U & $\mathrm{U}$ & $\mathrm{U}$ & U & U & $\mathrm{U}$ & Little Rock, Ark. & 19 & $\begin{array}{l}48 \\
76\end{array}$ & 24 & 3 & 2 & 2 & 3 \\
\hline Syracuse, N.Y. & 72 & 51 & 13 & 5 & - & 3 & 9 & New Orleans, La. & $\begin{array}{l}148 \\
237\end{array}$ & $\begin{array}{r}16 \\
155\end{array}$ & $\begin{array}{l}46 \\
5 ?\end{array}$ & $\begin{array}{l}15 \\
14\end{array}$ & 6 & 5 & 4 \\
\hline Trenton, N.J. & 34 & 18 & 13 & 3 & - & 一 & - & & 231 & $\begin{array}{r}155 \\
47\end{array}$ & 52 & 14 & 8 & 8 & 16 \\
\hline Utica, N.Y. & 12 & 7 & 4 & 1 & - & - & - & Shreveport, La. & 68 & 47 & 12 & 4 & 3 & 2 & 6 \\
\hline Yonkers, N.Y. & 14 & 14 & - & - & - & - & - & Tulsa, Okla. & & 87 & & 3 & 5 & 5 & 6 \\
\hline E.N. CENTRAL & 1,886 & 1,207 & 460 & 131 & 37 & 47 & 124 & MOUNTAIN & 1,081 & 700 & 242 & 81 & 46 & 12 & 67 \\
\hline Akron, Ohio & 45 & 30 & 14 & 1 & - & - & 7 & Albuquerque, N.M. & 134 & 82 & 33 & 12 & 6 & 1 & 11 \\
\hline Canton, Ohio & 32 & 23 & 7 & 1 & - & 1 & 3 & Boise, Idaho & 46 & 39 & 4 & 3 & - & - & 2 \\
\hline Chicago, III. & 365 & 191 & 108 & 44 & 9 & 9 & 25 & Colo. Springs, Colo. & 52 & 31 & 10 & 5 & 6 & - & 1 \\
\hline Cincinnati, Ohio & 109 & 63 & 29 & $\begin{array}{r}44 \\
6\end{array}$ & 5 & 6 & $\begin{array}{r}20 \\
8\end{array}$ & Denver, Colo. & 102 & 61 & 21 & 8 & 7 & 5 & 2 \\
\hline Cleveland, Ohio & 243 & 178 & 44 & 10 & 3 & 8 & $\begin{array}{r}0 \\
10\end{array}$ & Las Vegas, Nev. & 243 & 150 & 63 & 16 & 13 & 1 & 10 \\
\hline Columbus, Ohio & 223 & 148 & 57 & 10 & 3 & 5 & 22 & Ogden, Utah & 21 & 17 & 1 & 1 & 1 & 1 & 1 \\
\hline Dayton, Ohio & 139 & 97 & 34 & 6 & 2 & - & $\begin{array}{r}22 \\
5\end{array}$ & Phoenix, Ariz. & 185 & 104 & 59 & 15 & 4 & 3 & 11 \\
\hline Detroit, Mich. & 140 & 70 & 46 & 17 & 5 & 2 & $\begin{array}{l}5 \\
5\end{array}$ & Pueblo, Colo. & 30 & 24 & 4 & 1 & 1 & - & 1 \\
\hline Evansville, Ind. & 49 & 38 & 10 & - & 1 & - & 1 & Salt Lake City, Utah & 112 & 83 & 18 & 7 & 4 & - & 14 \\
\hline Fort Wayne, Ind. & 65 & 39 & 16 & 8 & 2 & - & 3 & Tucson, Ariz. & 156 & 109 & 29 & 13 & 4 & 1 & 14 \\
\hline Gary, Ind. & 8 & 3 & 3 & 1 & 1 & - & - & PACIFIC & 1,571 & 1,086 & 323 & 105 & 38 & 19 & 113 \\
\hline Grand Rapids, Mich. & 50 & 36 & 6 & 3 & 3 & 2 & 5 & Berkeley, Calif. & 12 & 7 & 3 & - & - & 2 & 3 \\
\hline Indianapolis, Ind. & 182 & 122 & 40 & 12 & 1 & 7 & 14 & Fresno, Calif. & 161 & 112 & 32 & 10 & 4 & 3 & 6 \\
\hline Lansing, Mich. & 43 & 33 & 6 & 4 & - & - & 6 & Glendale, Calif. & 17 & 15 & - & 2 & - & - & 1 \\
\hline Milwaukee, Wis. & U & U & U & U & U & U & $\mathrm{U}$ & Honolulu, Hawaii & 85 & 58 & 19 & 3 & 4 & 1 & 3 \\
\hline Peoria, III. & 52 & 30 & 15 & 4 & - & 3 & 3 & Long Beach, Calif. & 55 & 40 & 12 & 3 & - & - & 5 \\
\hline Rockford, III. & 46 & 28 & 13 & 1 & 2 & 2 & - & Los Angeles, Calif. & 223 & 144 & 54 & 14 & 9 & 2 & 31 \\
\hline South Bend, Ind. & 46 & 38 & 6 & 1 & - & 1 & 2 & Pasadena, Calif. & 21 & 14 & 5 & 2 & - & - & - \\
\hline Toledo, Ohio & U & U & U & U & U & U & $\bar{U}$ & Portland, Oreg. & 129 & 87 & 25 & 12 & 2 & 3 & 6 \\
\hline Youngstown, Ohio & 49 & 40 & 6 & 2 & - & 1 & 5 & Sacramento, Calif. & 203 & 133 & 50 & 18 & 2 & - & 12 \\
\hline W.N. CENTRAL & 680 & 452 & 152 & 37 & 17 & 20 & 32 & San Diego, Calif. & 123 & 93 & 19 & 3 & 4 & 4 & 7 \\
\hline Des Moines, lowa & 159 & 112 & 35 & 3 & 6 & 3 & 8 & San Francisco, Calif. & 103 & 73 & 21 & 5 & 3 & 1 & 8 \\
\hline Duluth, Minn. & 30 & 21 & 6 & 1 & 1 & 1 & 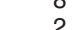 & San Jose, Calif. & 151 & 117 & 23 & 8 & 2 & 1 & 15 \\
\hline Kansas City, Kans. & 32 & 22 & 9 & - & - & 1 & 2 & Santa Cruz, Calif. & 32 & 23 & 7 & 1 & 1 & - & 3 \\
\hline Kansas City, Mo. & $\begin{array}{l}52 \\
69\end{array}$ & 47 & 14 & $\overline{3}$ & $\overline{4}$ & 1 & $\overline{2}$ & Seattle, Wash. & 101 & 58 & 27 & 10 & 4 & 2 & 5 \\
\hline Lincoln, Nebr. & 34 & 25 & 7 & 1 & 1 & - & 3 & Spokane, Wash. & 57 & 44 & 10 & 3 & - & - & 6 \\
\hline Minneapolis, Minn. & 57 & 30 & 12 & 8 & 2 & 5 & 2 & Tacoma, Wash. & 98 & 68 & 16 & 11 & 3 & - & 2 \\
\hline Omaha, Nebr. & 64 & 43 & 10 & 8 & 1 & 2 & 7 & TOTAL & $10,860^{\natural}$ & 7,091 & 2,500 & 730 & 299 & 231 & 618 \\
\hline St. Louis, Mo. & 90 & 47 & 26 & 8 & 1 & 6 & 6 & & & & & & & & \\
\hline St. Paul, Minn. & 42 & 26 & 12 & 2 & 1 & 1 & 2 & & & & & & & & \\
\hline Wichita, Kans. & 103 & 79 & 21 & 3 & - & - & - & & & & & & & & \\
\hline
\end{tabular}

\footnotetext{
U: Unavailable. _- No reported cases.
}

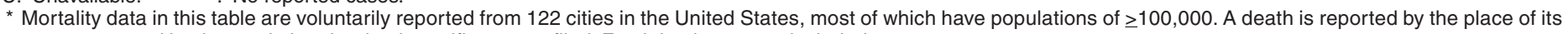
occurrence and by the week that the death certificate was filed. Fetal deaths are not included.

† Pneumonia and influenza.

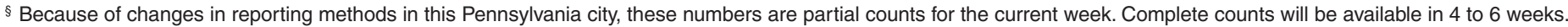

ๆ Total includes unknown ages. 
The Morbidity and Mortality Weekly Report (MMWR) Series is prepared by the Centers for Disease Control and Prevention (CDC) and is available free of charge in electronic format and on a paid subscription basis for paper copy. To receive an electronic copy each week, send an e-mail message to listserv@listserv.cdc.gov. The body content should read SUBscribe mmwr-toc. Electronic copy also is available from CDC's World-Wide Web server at http://www.cdc.gov/mmwr or from CDC's file transfer protocol server at ftp://ftp.cdc.gov/pub/publications/mmwr. To subscribe for paper copy, contact Superintendent of Documents, U.S. Government Printing Office, Washington, DC 20402; telephone 202-512-1800.

Data in the weekly MMWR are provisional, based on weekly reports to CDC by state health departments. The reporting week concludes at close of business on Friday; compiled data on a national basis are officially released to the public on the following Friday. Address inquiries about the $M M W R$ Series, including material to be considered for publication, to Editor, MMWR Series, Mailstop K-95, CDC, 1600 Clifton Rd., N.E., Atlanta, GA 30333; telephone 888-232-3228.

All material in the MMWR Series is in the public domain and may be used and reprinted without permission; citation as to source, however, is appreciated.

All MMWR references are available on the Internet at http://www.cdc.gov/mmwr. Use the search function to find specific articles.

Use of trade names and commercial sources is for identification only and does not imply endorsement by the U.S. Department of Health and Human Services.

References to non-CDC sites on the Internet are provided as a service to $M M W R$ readers and do not constitute or imply endorsement of these organizations or their programs by CDC or the U.S. Department of Health and Human Services. CDC is not responsible for the content of these sites. URL addresses listed in $M M W R$ were current as of the date of publication.

预U.S. Government Printing Office: 2005-733-116/00097 Region IV ISSN: 0149-2195 